\title{
Synthesis of Organoaluminum Fluorides and of an Oxo-Centered Trinuclear Carboxylate of Aluminum
}

\author{
Dissertation \\ zur Erlangung des Doktorgrades \\ der Mathematisch-Naturwissenschaftlichen Fakultäten \\ der Georg-August-Universität zu Göttingen
}

vorgelegt von

Hagen Hatop

aus Einbeck 
Hagen Hatop:

Synthesis of Organoaluminum Fluorides and of an Oxo-Centered Trinuclear Carboxylate of Aluminum / vorgelegt von Hagen Hatop

D7

Referent:

Korreferent:

Tag der mündlichen Prüfung:
Professor Dr. Dr. h. c. mult. H. W. Roesky

Priv.-Doz. Dr. U. Ritter

28.06.2001

(C) Das Recht zur freien elektronischen Publikation im Internet, zur Archivierung auf dem Dokumentenserver der SUB und zum Tausch der elektronischen Version mit anderen bibliothekarischen Tauschpartnern ist an die

SUB (Niedersächsische Staats- und Universitätsbibliothek Göttingen) übertragen.

Göttingen 2001

(C) Alle anderen Rechte vorbehalten. Ohne ausdrückliche Genehmigung von Hagen Hatop ist es nicht gestattet, das Buch oder Teile daraus auf fotomechanischem Weg (Fotokopie, Mikrokopie) zu vervielfältigen.

Hagen Hatop, Göttingen 2001

hatop@web.de 
meinen lieben Eltern 


\section{Acknowledgments}

This work was brought to fruition under the close guidance and following value-added advice from Professor Dr. Dr. h. c. mult. H. W. Roesky, Institute of Inorganic Chemistry, Georg-August-University Göttingen, between March 1998 and May 2001.

I hereby wish to profoundly thank my highly esteemed tutor,

Professor Dr. Dr. h. c. mult. H. W. Roesky,

for his unfailing interest in my work, his invariable support, encouragement, motivation, suggestions, and the working conditions conductive to the completion of this thesis. His inspiration largely accounts for the results achieved during this time.

I would also like to thank T. Labahn, Dr. M. Noltemeyer, H.-G. Schmidt, Dr. R. Herbst-Irmer, Prof. Dr. J. Magull, and Dr. A. Fischer for crystallographic measurements and Dr. M. Cimpoesu for doing electron density calculations.

I extend my thanks for spectroscopic and analytical investigations to Dr. D. Böhler (MS), T. Schuchardt (MS), R. Schöne (NMR), W. Zolke (NMR), Dr. G. Elter (NMR), M. Hesse (IR), and the staff of the Analytical Laboratory for their timely help and friendliness.

I thank all my colleagues of the research group for the good and motivating working atmosphere. I would particularly like to thank Dr. U. Ritter, Dr. C. Schnitter, J. Janssen, T. Blunck, J. Prust, A. Stasch, W. Zheng, H. Hohmeister, Dr. S. Kiel, Dr. T. Borrmann, H.-J. Schuster, Dr. M. Schormann, Dr. A. K. Mohamed, Dr. D. Chakraborty, Dr. S. Bhandari and Dr. P. Böttcher for useful discussions and creative working atmosphere.

I thank Dr. M. Witt for helpful discussions and final proof reading.

I want to express my special thanks to my lab colleagues Dr. A. Klemp and M. Schiefer for cooperative discussions and a friendly working atmosphere.

I want to thank for financial aid i obtained from the Gustav-Tammann-Award, a halftime job at the Georg-August-University Göttingen, and my parents.

I also want to thank Olesya for the support and inspiration I got from her :-) 
1. Introduction

1.1. Aluminum Halides - Aluminum Fluorides ............................................ 1

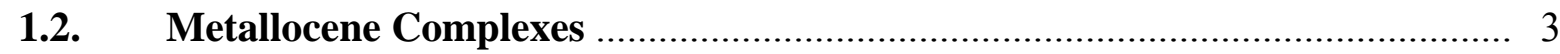

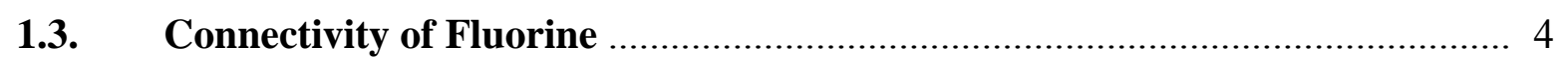

1.4. Oxo-Centered Trinuclear Carboxylates ........................................................ 5

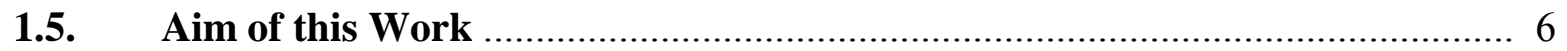

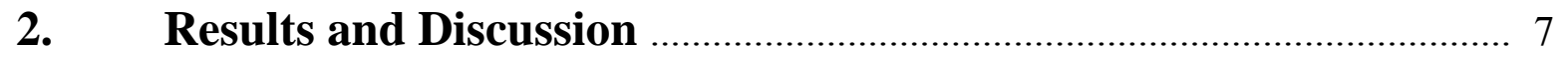

2.1. Synthesis of $\left[\mathrm{Cp}_{2} \mathrm{ZrMe}\right](\mu-\mathrm{F})\left[\mathrm{F}_{2} \mathrm{AlC}\left(\mathrm{SiMe}_{3}\right)_{3}\right](7)$

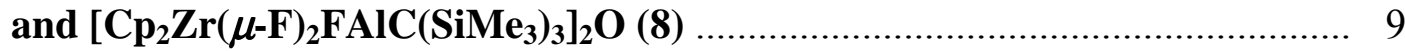

2.1.1. Investigations on the Catalytic Activity of 7 .............................................. 13

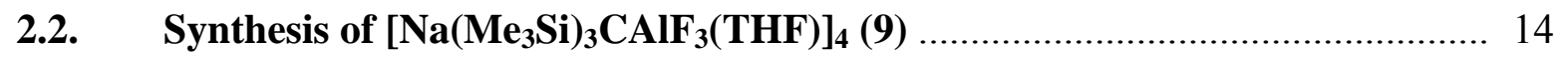

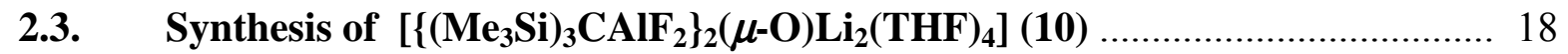

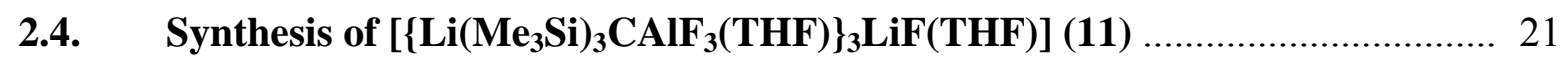

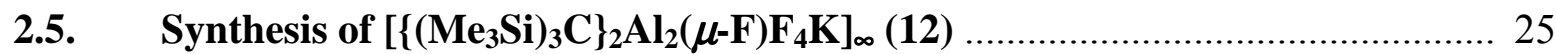

2.6. Synthesis of New Organoaluminum Fluorides ....................................... 30

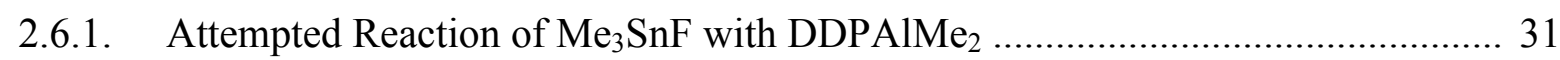

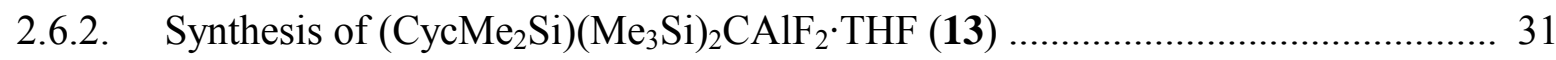

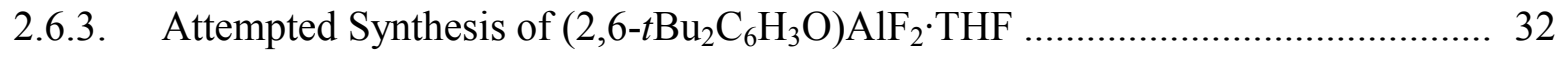

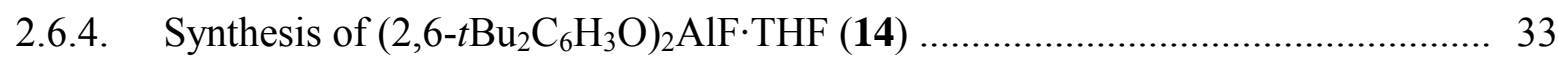

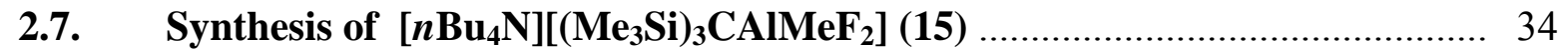

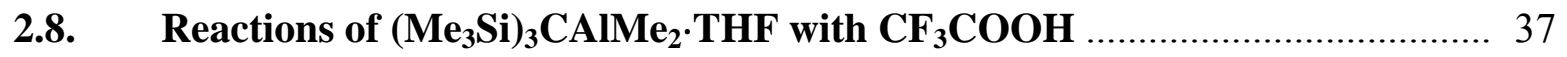

2.8.1. Reaction of $\left(\mathrm{Me}_{3} \mathrm{Si}\right)_{3} \mathrm{CAlMe}$. THF with $\mathrm{CF}_{3} \mathrm{COOH}$ in a $1: 1$ molar ratio.

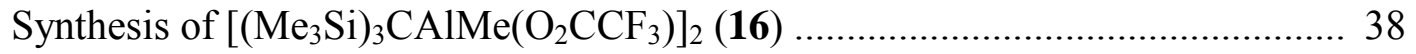

2.8.2. Reaction of $\left(\mathrm{Me}_{3} \mathrm{Si}\right)_{3} \mathrm{CAlMe}_{2} \cdot \mathrm{THF}$ with $\mathrm{CF}_{3} \mathrm{COOH}$ in a $1: 2$ molar ratio. 
2.8.3. Reaction of $\left(\mathrm{Me}_{3} \mathrm{Si}\right)_{3} \mathrm{CAlMe} 2$.THF with $\mathrm{CF}_{3} \mathrm{COOH}$ in a $1: 3$ molar ratio.

Synthesis of

$\left[\mathrm{Al}_{3}\left(\mu_{3}-\mathrm{O}\right)\left(\mu-\mathrm{O}_{2} \mathrm{CCF}_{3}\right)_{6}(\mathrm{THF})_{3}\right]^{+}\left[\left(\mathrm{Me}_{3} \mathrm{Si}\right)_{3} \mathrm{CAl}\left(\mathrm{OC}(\mathrm{O}) \mathrm{CF}_{3}\right)_{3}\right]^{-}(\mathbf{1 8}) \ldots \ldots \ldots \ldots \ldots \ldots . . . . . . . . .40$

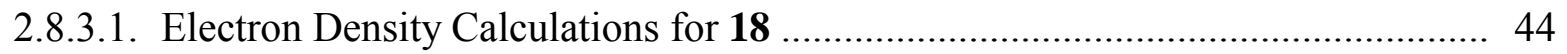

3. Summary and Outlook .................................................................... 48

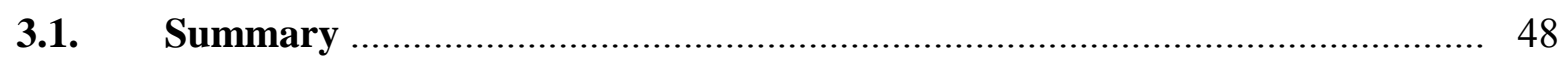

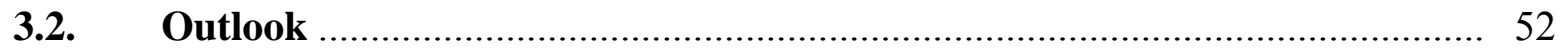

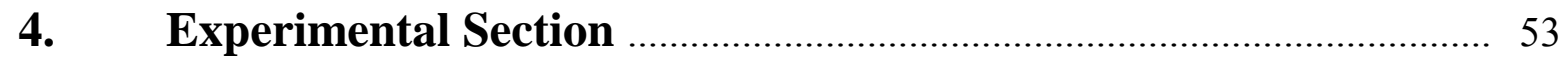

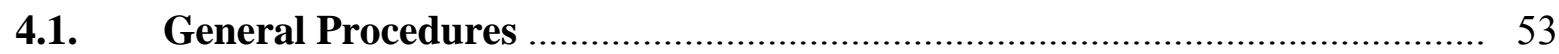

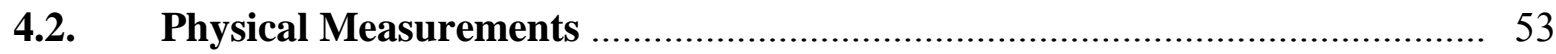

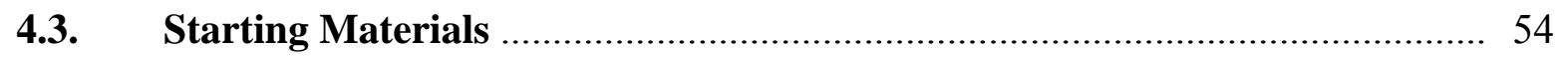

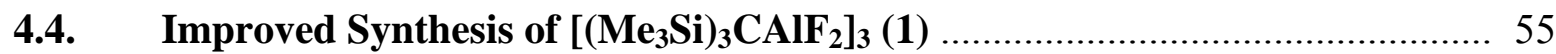

4.5. Synthesis of $\left[\mathrm{Cp}_{2} \mathrm{ZrMe}\right](\mu-\mathrm{F})\left[\mathrm{F}_{2} \mathrm{AlC}\left(\mathrm{Si} \mathrm{Me}_{3}\right)_{3}\right](7)$ and $\left[\mathrm{Cp}_{2} \mathrm{Zr}(\mu \text {-F })_{2} \mathrm{FAl}-\right.$

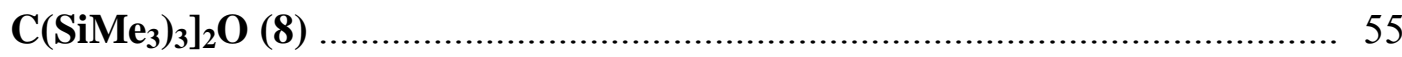

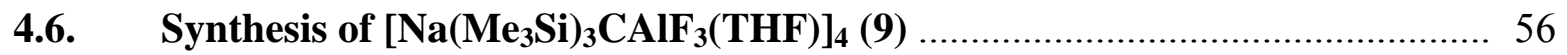

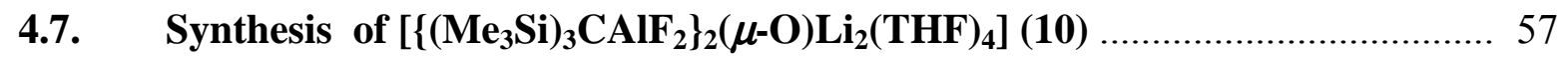

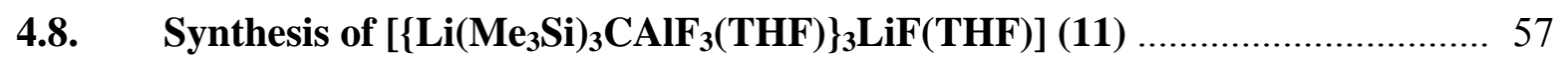

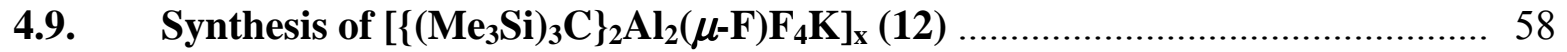

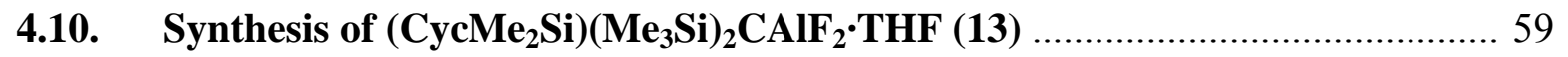

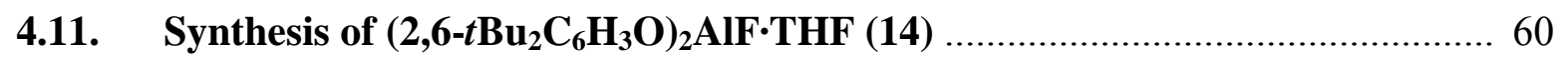

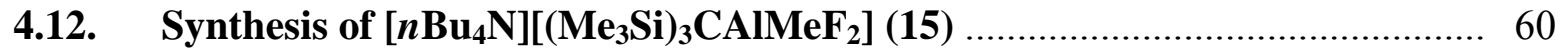

4.13. Reaction of $\left(\mathrm{Me}_{3} \mathrm{Si}\right)_{3} \mathrm{CAIMe} \cdot \mathrm{THF}$ with $\mathrm{CF}_{3} \mathrm{COOH}$ in a $1: 1$ molar ratio. Synthesis of $\left[\left(\mathrm{Me}_{3} \mathrm{Si}\right)_{3} \mathrm{CAIMe}\left(\mathrm{O}_{2} \mathrm{CCF}_{3}\right)\right]_{2}(16)$ 
4.14. Reaction of $\left(\mathrm{Me}_{3} \mathrm{Si}\right)_{3} \mathrm{CAIMe}$. $\mathrm{THF}$ with $\mathrm{CF}_{3} \mathrm{COOH}$ in a $1: 2$ molar ratio. Synthesis of $\left[\left(\mathrm{Me}_{3} \mathrm{Si}\right)_{3} \mathrm{CAl}\left(\mathrm{O}_{2} \mathrm{CCF}_{3}\right)_{2}\right]_{2}(17)$ 62

4.15. Reaction of $\left(\mathrm{Me}_{3} \mathrm{Si}\right)_{3} \mathrm{CAIMe}$. $\mathrm{THF}$ with $\mathrm{CF}_{3} \mathrm{COOH}$ in a $1: 3$ molar ratio. Synthesis of $\left[\mathrm{Al}_{3}\left(\mu_{3}-\mathrm{O}\right)\left(\mu-\mathrm{O}_{2} \mathrm{CCF}_{3}\right)_{6}(\mathrm{THF})_{3}\right]^{+}\left[\left(\mathrm{Me}_{3} \mathrm{Si}\right)_{3} \mathrm{CAl}\left(\mathrm{OC}(\mathrm{O}) \mathrm{CF}_{3}\right)_{3}\right]^{-}(18)$ 62

5. Handling and Disposal of Wastes and Residual Wastes 64

6. X-ray Crystal Data and Refinement Details 65

7. References 73 


\section{Abbreviations}

\begin{tabular}{|c|c|}
\hline Anal. Calcd & analysis calculated \\
\hline av & average \\
\hline$i \mathrm{Bu}$ & iso-butyl \\
\hline$t \mathrm{Bu}$ & tert-butyl \\
\hline $\mathrm{C}$ & Celsius \\
\hline $\mathrm{Cp}$ & $\eta^{5}$-cyclopentadienyl \\
\hline Cp' & substituted cyclopentadienyl \\
\hline $\mathrm{Cp}^{*}$ & $\eta^{5}$-pentamethylcyclopentadienyl \\
\hline Cyc & cyclohexyl \\
\hline $\mathrm{d}$ & doublet \\
\hline$\delta$ & chemical shift \\
\hline DDP-H & $2-\{(2,6$-diisopropylphenyl $)$ amino $\}-4-\{(2,6$-diisopropylphenyl $)$ imino $\}-$ \\
\hline & 2-pentene \\
\hline $\operatorname{deg}$ & degree \\
\hline diff. peak & difference peak \\
\hline DBP-H & 2,6-di-tert-butylphenol \\
\hline DBMP-H & 2,6-di-tert-butyl-4-methylphenol \\
\hline ed. & edition \\
\hline EI & electron ionization \\
\hline Et & ethyl \\
\hline eq & equivalent(s) \\
\hline FAB & fast atom bombardement \\
\hline $\mathrm{FW}$ & formula weight \\
\hline $\mathrm{h}$ & hours \\
\hline HSAB & hard and soft acids and bases \\
\hline$n$ hexane & normal-hexane \\
\hline $\mathrm{Hz}$ & Hertz \\
\hline
\end{tabular}




\begin{tabular}{|c|c|}
\hline IR & infrared \\
\hline$J$ & coupling constant \\
\hline $\mathrm{K}$ & Kelvin \\
\hline$\lambda$ & wavelength \\
\hline M & metal \\
\hline$M^{+}$ & molecular ion \\
\hline $\mathrm{m}$ & multiplet \\
\hline MAO & methylaluminoxane \\
\hline $\mathrm{Me}$ & methyl \\
\hline 4-Mepy & 4-methylpyridine \\
\hline $\min$ & minute \\
\hline $\mathrm{mp}$ & melting point \\
\hline MS & mass spectrometry \\
\hline$m / z$ & mass/charge \\
\hline$\mu$ & bridging \\
\hline NMR & nuclear magnetic resonance \\
\hline$\circ$ & degree \\
\hline $\mathrm{Ph}$ & phenyl \\
\hline ppm & parts per million \\
\hline$i \operatorname{Pr}$ & iso-propyl \\
\hline Py & pyridine \\
\hline $\mathrm{R}, \mathrm{R}^{\prime}, \mathrm{R}^{\prime \prime}$ & organic substituent \\
\hline s & singlet \\
\hline Subl. point & sublimation point \\
\hline $\mathrm{t}$ & triplet \\
\hline TBADF & tetra- $n$ butylammonium hydrogen difluoride \\
\hline THF & tetrahydrofuran \\
\hline Tris & tristrimethylsilylmethyl \\
\hline$Z$ & number of molecules in the cell \\
\hline
\end{tabular}


1. Introduction

\subsection{Aluminum Halides - Aluminum Fluorides}

Aluminum trifluoride is a colorless solid which is nearly insoluble in water, acids and bases. It differs from the other aluminum trihalides by having a much higher melting and sublimation point, having a greater heat of formation and finally in different coordination numbers [1].

$\begin{array}{lcccc} & \mathrm{AlF}_{3} & \mathrm{AlCl}_{3} & \mathrm{AlBr}_{3} & \mathrm{AlI}_{3} \\ \text { melting point } /{ }^{\circ} \mathrm{C} & 1290 & 192 & 98 & 189 \\ \text { Subl. point }(1 \mathrm{~atm}) /{ }^{\circ} \mathrm{C} & 1272 & 180 & 256 & 382 \\ \Delta H_{\mathrm{f}}^{\circ} / \mathrm{kJ} \mathrm{mol}^{-1} & 1498 & 707 & 527 & 310\end{array}$

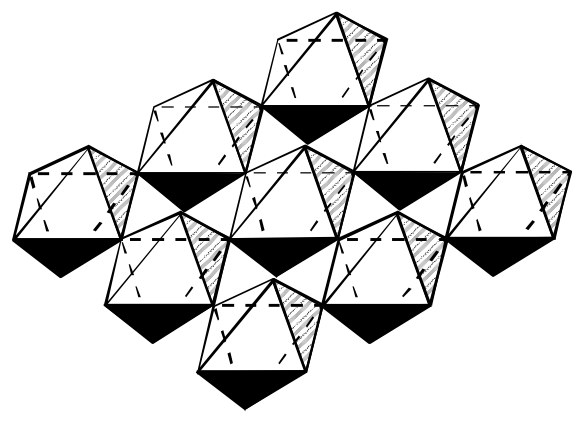

$\mathbf{a}$

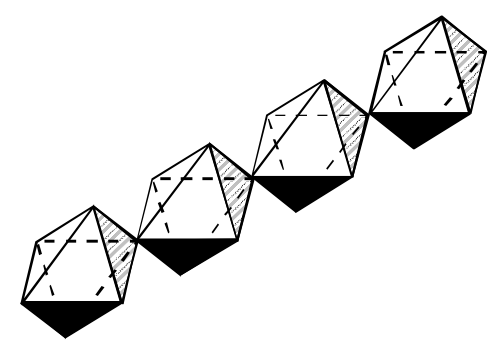

$\mathbf{b}$

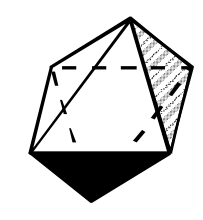

c

$\mathrm{AlF}_{3}$ forms with other alkali and metal fluorides different anionic compositions [2,3,4]:

- $\mathrm{M}\left[\mathrm{AlF}_{4}\right]\left(\mathrm{NaAlF}_{4},(\mathbf{a})\right)$ sharing of 4 equatorial vertices, layer of octahedral $\left\{\mathrm{AlF}_{6}\right\}$ units

$-\mathrm{M}_{2}\left[\mathrm{AlF}_{5}\right]\left(\mathrm{Tl}_{2} \mathrm{AlF}_{5},(\mathbf{b})\right)$ sharing of 2 opposite vertices, chain of octahedral $\left\{\mathrm{AlF}_{6}\right\}$ units

- $\mathrm{M}_{3}\left[\mathrm{AlF}_{6}\right]\left(\mathrm{Na}_{3} \mathrm{AlF}_{6},(\mathbf{c})\right)$ no vertex is shared, isolated octahedral $\left\{\mathrm{AlF}_{6}\right\}$ units.

Edge or face sharing of octahedral $\left\{\mathrm{AlF}_{6}\right\}$ units are not observed.

In $\mathrm{AlF}_{3}$ each aluminum is surrounded by six fluorine atoms to form a distorted octahedron. The coordination number six in solid $\mathrm{AlCl}_{3}$ decreases at $192{ }^{\circ} \mathrm{C}$ to four in the molecular dimer 
$\mathrm{Al}_{2} \mathrm{Cl}_{6}$ accompanied by a dramatic increase in volume (plus $85 \%$ ). $\mathrm{AlBr}_{3}$ and $\mathrm{AlI}_{3}$ are also four-coordinated. The trihalides of aluminum form a large number of addition compounds or complexes [5] which are used in Friedel-Crafts catalysis [6] and $\mathrm{AlCl}_{3}$ especially for polymerization reactions and olefin cracking in technical processes [2].

There is an extensive scope in the use of aluminum fluorides. The most important practical application is cryolite $\left(\mathrm{Na}_{3} \mathrm{AlF}_{6}\right)$ as a commodity chemical for electrochemical industrial processes such as the electrolysis of aluminum oxide [1,2,7]. Another relevant use of aluminum fluorides is as catalysts for the synthesis of chlorofluorocarbon alternatives [8].

Several articles concerning aluminum fluorides have been reported. Metal fluoride salts were found to activate aluminum in water to react with carbonyl compounds to give pinacol coupling products [9]. Aluminum trifluoride shows several biological activities like inhibition of nitrogenase [10] or decreasing the number of some special calcium channels in cells [11]. Recently it has been shown that aluminum fluoride is a storage matrix for atomic hydrogen [12]. Organoaluminum fluorides are found among the pioneering work of Ziegler [13]. There is also potential importance of these compounds as models for certain catalytic reactions [14]. $\mathrm{X}$-ray crystallography analysis gave structural proof for the existence of tetrahedral $\left[\mathrm{AlF}_{4}\right]^{-}$in organic cation salts of the tetrafluoroaluminate anion [15]. The reduction of $\left(\mathrm{C}_{5} \mathrm{H}_{4} \mathrm{Me}\right)_{2} \mathrm{TiF}_{2}$ with aluminum yields the Werner-type coordination compound $\left[\left(\mathrm{C}_{5} \mathrm{H}_{4} \mathrm{Me}\right)_{2} \mathrm{TiF}_{2}\right]_{3} \mathrm{Al}(\mathbf{d})$ with six-coordinated aluminum in the center [16].

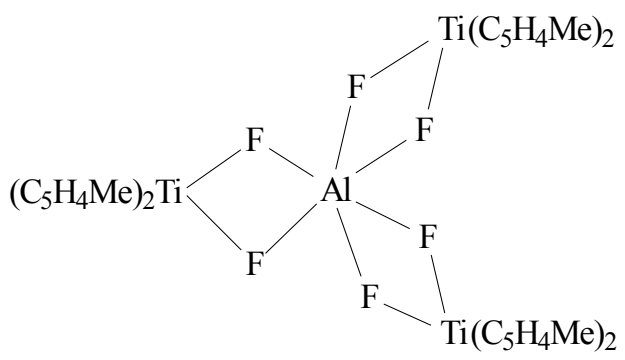

d

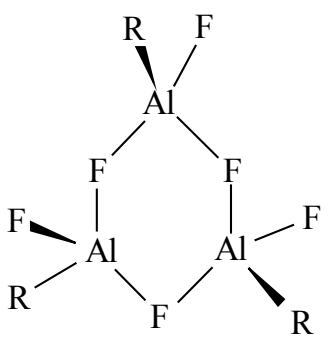

e 
There are several examples for diorganoaluminum fluorides [17]. Organoaluminum difluorides are a new field of research. Until 1995 they were found to be only accessible in special cases and not structurally characterized [18]. This changed two years later with the synthesis and the crystal structure of the trimeric organoaluminum difluoride $\left[\mathrm{RAlF}_{2}\right]_{3}(\mathrm{R}=$ $\left.\mathrm{N}\left(\mathrm{SiMe}_{3}\right) 2,6-i \mathrm{Pr}_{2} \mathrm{C}_{6} \mathrm{H}_{3}\right)(\mathbf{e})[19]$.

\subsection{Metallocene Complexes}

Metallocene complexes [20] were found to be useful for catalysis in the polymerization of ethene [21-23]. The modification of the Cp ligand leads, on account of a stereorigid sphere around the metal center, to compounds that are able to produce syndiotactic or isotactic polypropene [24]. Sinn and Kaminsky reported in 1980 that methylalumoxane (MAO) increases enormously the activity of the metallocene catalysts [25]. MAO is always used in a great excess. The mode of action of MAO is due to a lack of model compounds not yet understood [26-28]. It was searched for other cocatalysts that coordinate weakly to the catalytic active $\left[\mathrm{Cp}_{2}^{\prime} \mathrm{MX}\right]^{+}$cation $(\mathrm{M}=\mathrm{Ti}, \mathrm{Zr} ; \mathrm{X}=\mathrm{Me}, \mathrm{Cl}, \mathrm{F})$ [29]. The first examples of $\mathrm{X}$-ray structural characterized zirconocene complexes which polymerize propene with high activity are perfluorinated phenylboranates like $\left[\mathrm{Cp}_{2}^{\prime} \mathrm{ZrMe}\right]^{+}\left[\mathrm{B}\left(\mathrm{C}_{6} \mathrm{~F}_{5}\right)_{4}\right]^{-} \quad[30]$. The perfluorinated phenylaluminum compound $\left[\mathrm{Al}\left(\mathrm{C}_{6} \mathrm{~F}_{5}\right)_{3} \cdot \mathrm{THF}\right]$, analogue to $\mathrm{B}\left(\mathrm{C}_{6} \mathrm{~F}_{5}\right)_{3}$, decomposes spontaneously and proved to be unusable for further experiments [31]. Marks et al. synthesized catalytically active zirconocenes with a bridging methyl group [(1,2$\left.\left.\mathrm{Me}_{2} \mathrm{C}_{5} \mathrm{H}_{3}\right)_{2} \mathrm{ZrMe}\right]\left(\mu\right.$-Me) $\left[\mathrm{B}\left(\mathrm{C}_{6} \mathrm{~F}_{5}\right)_{3}\right]$ (f, fluorine atoms are omitted) by treatment of $(1,2-$ $\left.\mathrm{Me}_{2} \mathrm{C}_{5} \mathrm{H}_{3}\right)_{2} \mathrm{ZrMe}_{2}$ with $\mathrm{B}\left(\mathrm{C}_{6} \mathrm{~F}_{5}\right)_{3}[32]$.

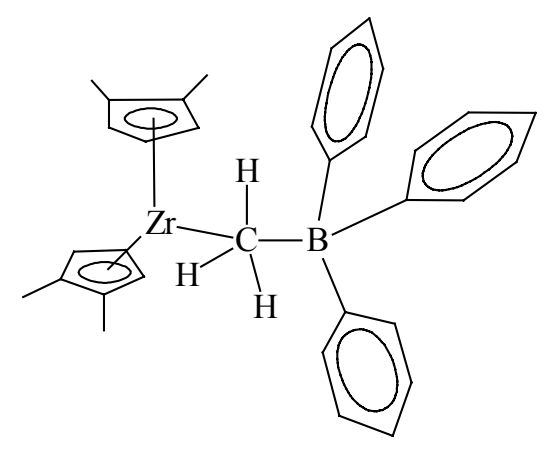

f

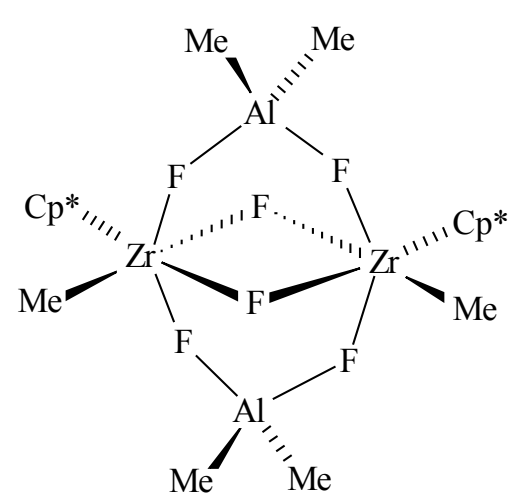

g 
Soluble early transition metal fluorides like $\mathrm{Cp}^{*} \mathrm{ZrF}_{3}$ have been easy accessible for a few years $[33,34]$. The small size of the fluorine atom and the high electron density cause a strong $\pi$-acceptor capability of the metal center [35] which gives high potential for use as MAO alternative cocatalysts. Fluorinated half-sandwich complexes of titanium, such as $\mathrm{CpTiF}_{3}$, have been used as catalysts in syndiospecific styrene polymerization [36] and seem to be useful as model compounds for catalysis which are characterizable by X-ray single crystal structure analysis.

The reaction of $\mathrm{Cp}^{*} \mathrm{ZrF}_{3}$ with $\mathrm{AlMe}_{3}$ resulted in the complex cis-[Cp*ZrMe$(\mu-\mathrm{F})-$ $\left.(\mu-\mathrm{F})_{2} \mathrm{AlMe}_{2}\right]_{2}(\mathrm{~g})$ approaching the structural requirements of a catalytically active system. However, this compound is only active in the presence of MAO in the polymerization of olefins [37].

\subsection{Connectivity of Fluorine}

Fluorine, the first member of the halogen group, is expected to be monocovalent or single charged to form anions [38]. A linear symmetric bridge of fluorine was first indentified in dialuminum anions $\left[\mathrm{R}_{3} \mathrm{Al}(\mu-\mathrm{F}) \mathrm{AlR}_{3}\right]^{-}(\mathrm{R}=\mathrm{Me}, \mathrm{Et})$ by $\mathrm{X}$-ray diffraction analysis of the compound $\mathrm{KF} \cdot 2 \mathrm{AlEt}_{3}$ [39]. This bridging ability allows the encapsulation of fluorine atoms in cage compounds as in $\left[\left(\mathrm{Cp}^{\prime} \mathrm{TiF}_{2}\right)_{5} \mathrm{AlF}_{2}\left(\mu_{6}-\mathrm{F}\right) \cdot \mathrm{THF}\right]\left(\mathrm{Cp}^{\prime}=\mathrm{C}_{5} \mathrm{H}_{4} \mathrm{SiMe}_{3}\right)$ (h) [38]. It also can be found in host-guest complexation, the template of the cation is structure directing and leads to interesting systems like $\left[\mathrm{Ph}_{4} \mathrm{P}\right]^{+}\left[\left(\mathrm{Cp}_{2}{ }_{2} \mathrm{Ti}_{2} \mathrm{~F}_{7}\right)_{2} \mathrm{Na}\right]^{-}$(i) [40].

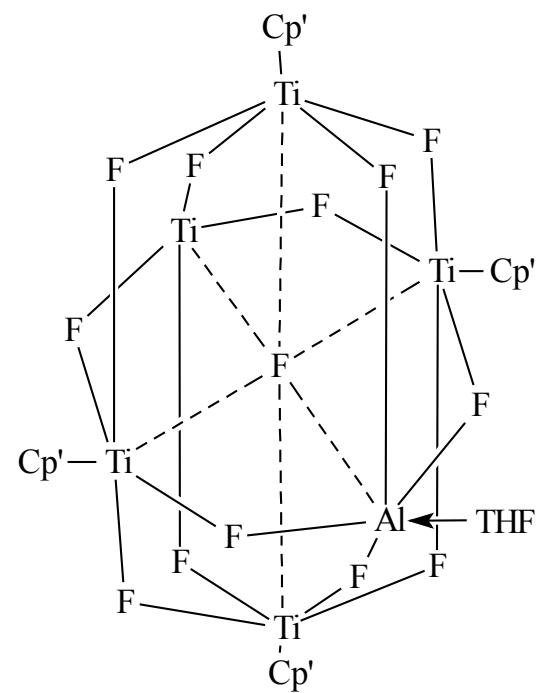

h

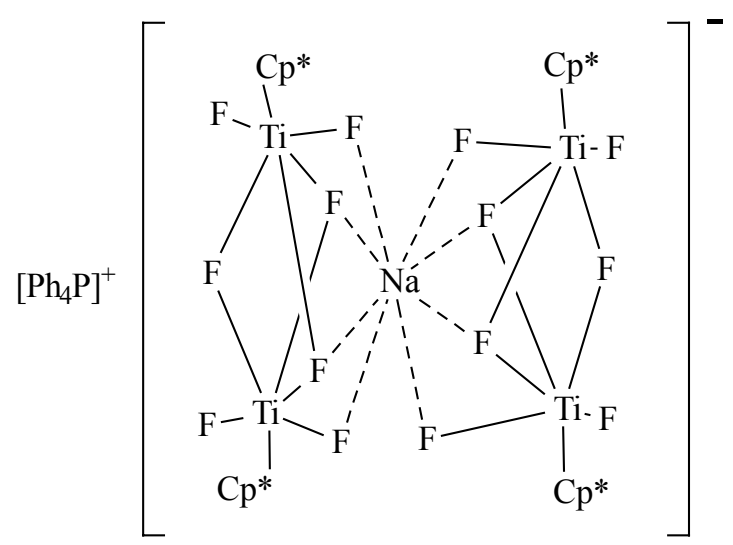




\subsection{Oxo-Centered Trinuclear Carboxylates}

Oxo-centered trinuclear carboxylates are a well-established class of complexes, referred to as "basic carboxylates" of the general formula $\left[\mathrm{M}_{3}\left(\mu_{3}-\mathrm{O}\right)\left(\mu-\mathrm{O}_{2} \mathrm{CR}\right)_{6} \mathrm{~L}_{3}\right](\mathrm{M}=$ metal; $\mathrm{L}=$ ligand (for example: Pyridine derivative, THF, water, etc.); $\mathrm{R}=\mathrm{CH}_{3}, \mathrm{Ph}, \mathrm{CF}_{3}, \mathrm{H}$ ).

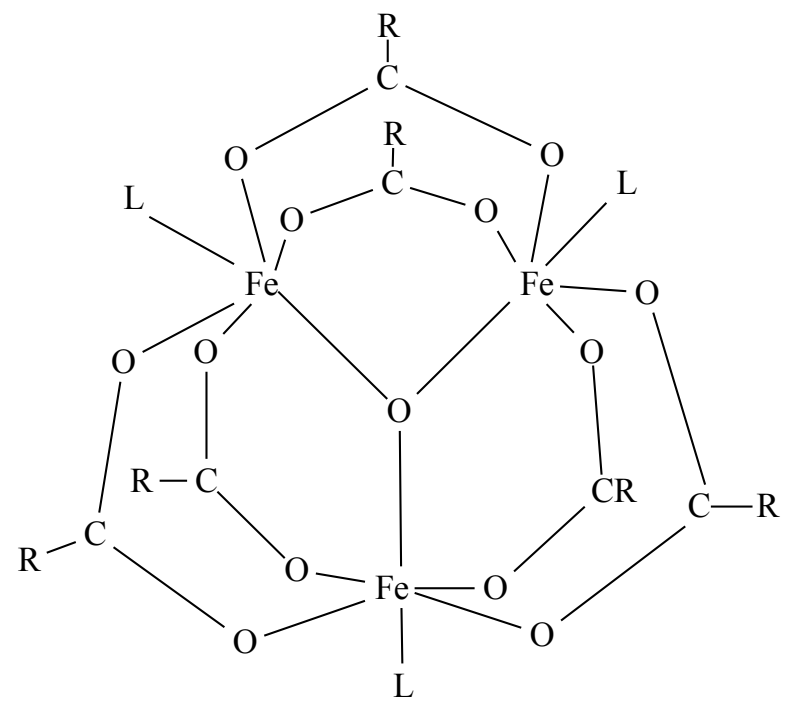

j

There are various addition compounds of oxo-centered trinuclear carboxylates of transition metals $(\mathrm{M}=\mathrm{V}, \mathrm{Cr}, \mathrm{Mn}, \mathrm{Fe}, \mathrm{Co}, \mathrm{Ru}, \mathrm{Rh}$ and $\mathrm{Ir})$ [41]. More than 100 examples can be found for the iron derivatives, one is $\left[\mathrm{Fe}_{3}\left(\mu_{3}-\mathrm{O}\right)\left(\mu-\mathrm{O}_{2} \mathrm{CCH}_{3}\right)_{6}(\mathrm{py})_{3}\right](\mathbf{j})\left(\mathrm{R}=\mathrm{CH}_{3}, \mathrm{~L}=\mathrm{Py}\right)$ [42].

"Basic carboxylates" of aluminum are, due to a highly symmetric and a more simple electron configuration compared to transition metals, good model molecules for computational electron density analysis. 


\subsection{Aims of this Work}

Based on the described material in the sections $1.1-1.4$, it is obvious that organoaluminum fluorides are, due to the Lewis acid character of aluminum in organoaluminum fluorides and the bridging ability of the Lewis base fluoride, qualified precursors for syntheses of new interesting cluster compounds.

The aims of this work have been (1) the synthesis of Ziegler-Natta catalyst relevant systems $\left[\mathrm{Cp}_{2-\mathrm{y}} \mathrm{ZrX}_{1+\mathrm{y}}\right]\left(\mu-\mathrm{X}^{\prime}\right)\left[\mathrm{RAlF}_{2}\right]\left(\mathrm{Cp}^{\prime}=\mathrm{Cp}\right.$ or substituted $\mathrm{Cp} ; \mathrm{X}, \mathrm{X}^{\prime}=\mathrm{Me}, \mathrm{Cl}$ or $\mathrm{F} ; \mathrm{R}=\mathrm{Ligand}$; $y=0$ or 1), (2) the generation of new bimetallic organoaluminum fluorides, (3) access to new organoaluminum fluorides and (4) to investigate the reaction of $\left(\mathrm{Me}_{3} \mathrm{Si}\right)_{3} \mathrm{CAlMe} \mathrm{CH}_{2} \cdot \mathrm{THF}$ with $\mathrm{CF}_{3} \mathrm{COOH}$. 


\section{Results and Discussion}

The trimeric compound $\left[\left(\mathrm{Me}_{3} \mathrm{Si}\right)_{3} \mathrm{CAlF}_{2}\right]_{3}(\mathbf{1})$ is a Lewis acid capable of accepting fluoride ions [43] or other Lewis bases (Scheme 1).

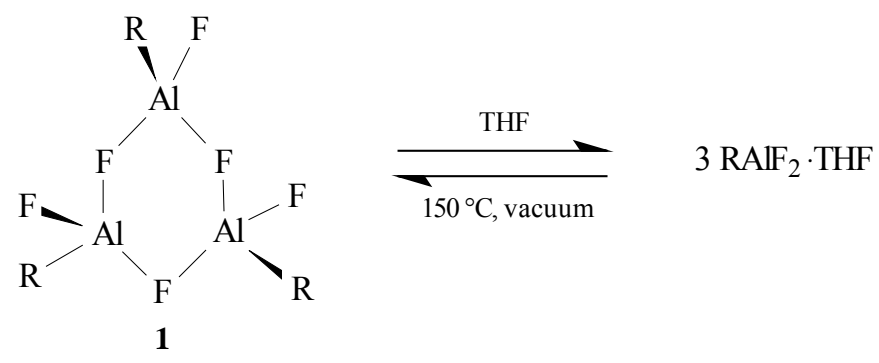

Scheme 1. $\mathrm{R}=\mathrm{C}\left(\mathrm{SiMe}_{3}\right)_{3}$. The reactivity of 1 versus the Lewis base THF.

Few composites with $\mathbf{1}$ and fluoride anions and different counter cations, which have been structurally characterized by X-ray analysis, are known (Scheme 2) [43-46]:

- $\quad\left[\left\{\left(\mathrm{Me}_{3} \mathrm{Si}\right)_{3} \mathrm{C}\right\}_{4} \mathrm{Al}_{4} \mathrm{~K}_{2}(\mu-\mathrm{F})_{2} \mathrm{~F}_{8}(\mathrm{THF})_{4}\right](2)$,

- $\left.\quad[\text { Ag(toluene })_{3}\right]^{+}\left[\left\{\left(\left(\mathrm{Me}_{3} \mathrm{Si}\right)_{3} \mathrm{C}\right)_{2} \mathrm{Al}_{2}(\mu-\mathrm{F}) \mathrm{F}_{4}\right\}_{2} \mathrm{Li}\right]^{-}(\mathbf{3})$,

- $\left[\mathrm{AlF}_{2}(\mathrm{THF})_{4}\right]^{+}\left[\left\{\left(\mathrm{Me}_{3} \mathrm{Si}\right)_{3} \mathrm{C}\right\}_{2} \mathrm{Al}_{2}(\mu-\mathrm{F}) \mathrm{F}_{4}\right]^{-}(\mathbf{4})$,

- $\quad\left[\mathrm{Li}\left(\mathrm{Me}_{3} \mathrm{Si}_{3} \mathrm{CAlF}_{3}(\mathrm{THF})\right]_{4}(\mathbf{5})\right.$, and

- $\quad\left[\mathrm{Me}_{3} \mathrm{C}_{5} \mathrm{H}_{2} \mathrm{NH}\right]^{+}\left[\left(\mathrm{Me}_{3} \mathrm{Si}\right)_{3} \mathrm{CAlF}_{3}\right]^{-}(\mathbf{6})$.

These compounds contain the anions $\left[\left(\mathrm{Me}_{3} \mathrm{Si}_{3} \mathrm{CAlF}_{3}\right]^{-}(\mathbf{5}\right.$ and $\mathbf{6})$ and $\left[\left(\mathrm{Me}_{3} \mathrm{Si}_{3}\right)_{3} \mathrm{CAlF}_{2}(\mu-\mathrm{F}) \mathrm{F}_{2^{-}}\right.$ $\left.\mathrm{AlC}\left(\mathrm{SiMe}_{3}\right)_{3}\right]^{-}(\mathbf{2}, \mathbf{3}$, and 4) respectively. 4 and $\mathbf{6}$ contain non coordinating anions. Coordination of the anion with the cation in $\mathbf{4}$ is precluded by the use of the coordinating solvent THF, while in $\mathbf{6}$ the cation is coordinatively saturated. 2, 3 and 5 possess metal cations acting as structure directing templates [47]. In the synthetic strategy for $\mathbf{3}$ a hard $\left(\mathrm{Li}^{+}\right)$and a soft $\left(\mathrm{Ag}^{+}\right)$cation were used according to the HSAB concept of Pearson [48]. The $\mathrm{Ag}^{+}$exhibits no interaction with the fluorine atoms of the anion. Special attention has been drawn to compositions containing a strong coordinating solvent like THF or a weakly coordinating 
solvent like toluene [49]. Only compounds without strong coordinating solvents are likely to be useful for Ziegler-Natta catalysis [50]. For 5 it is observed that the cube dissociates in THF to form a $\left[\left(\mathrm{Me}_{3} \mathrm{Si}_{3} \mathrm{CAlF}_{3}\right]^{-}\right.$anion and a $\left[\mathrm{Li}(\mathrm{THF})_{4}\right]^{+}$cation. However, sometimes THF and other coordinating solvents may be necessary for the crystallization in order to get structural informations [49].

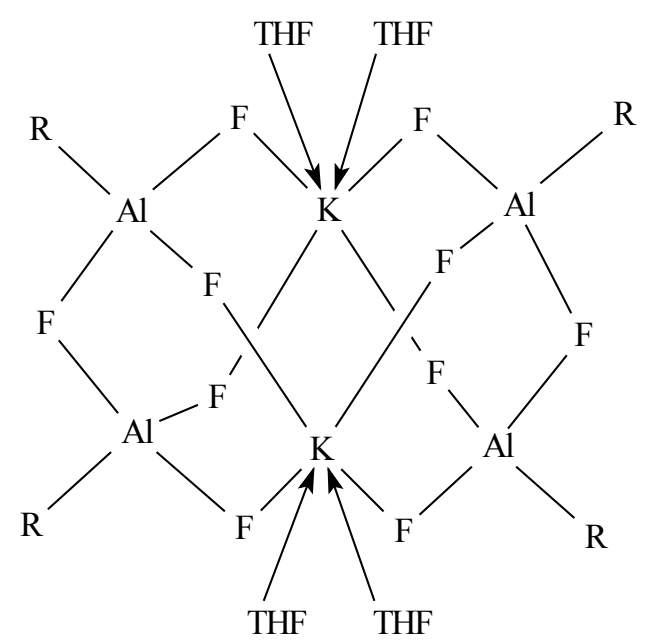

2

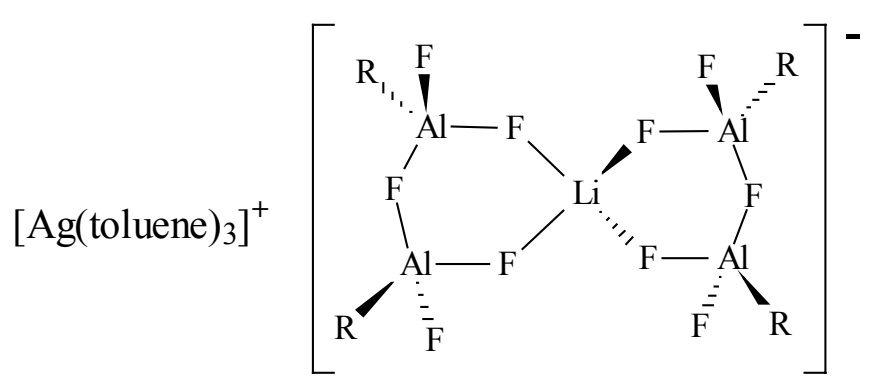

3<smiles>[R][N+](F)(F)[I-][I+]([R])(F)F</smiles>

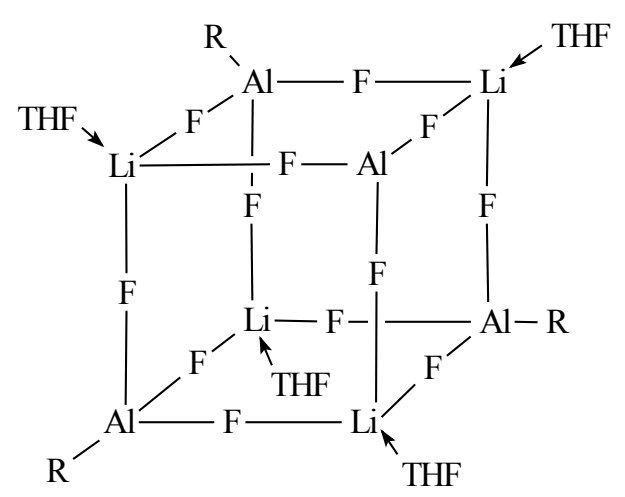

5

Scheme 2. $\mathrm{R}=\mathrm{C}\left(\mathrm{SiMe}_{3}\right)_{3}$. 


\subsection{Synthesis of $\left[\mathrm{Cp}_{2} \mathrm{ZrMe}\right](\mu-\mathrm{F})\left[\mathrm{F}_{2} \mathrm{AIC}\left(\mathrm{SiMe}_{3}\right)_{3}\right] \quad$ (7) and $\left[\mathrm{Cp}_{2} \operatorname{Zr}(\mu-\mathrm{F})_{2^{-}}\right.$ $\left.\mathrm{FAIC}\left(\mathrm{SiMe}_{3}\right)_{3}\right]_{2} \mathrm{O}(8)$}

Compounds of type $\left[\mathrm{Cp}^{\prime}{ }_{2-\mathrm{y}} \mathrm{ZrX}_{1+\mathrm{y}}\right]\left(\mu-\mathrm{X}^{\prime}\right)\left[\mathrm{F}_{2} \mathrm{AIR}\right]\left(\mathrm{Cp}^{\prime}=\mathrm{Cp}\right.$ or substituted $\mathrm{Cp} ; \mathrm{X}, \mathrm{X}^{\prime}=\mathrm{Me}$, $\mathrm{Cl}$ or $\mathrm{F} ; \mathrm{R}=$ Ligand; $\mathrm{y}=0$ or 1 ) are of particular interest as catalysts for olefin polymerization [51]. Marks et al. published a system with a weak bridging fluorine between an aluminum and a zirconium atom $\left[\mathrm{Cp}^{*}{ }_{2} \mathrm{ZrMe}(\mu-\mathrm{F}) \mathrm{Al}\left(\mathrm{C}_{12} \mathrm{~F}_{9}\right)_{3}\right]$ [52] that shows catalytical activity for ethene polymerisation. The $\left[\left(\mathrm{Me}_{3} \mathrm{Si}_{3} \mathrm{CAlF}_{3}\right]^{-}\right.$anion should also be able to stabilize the $\left[\mathrm{Cp}_{2} \mathrm{ZrMe}\right]^{+}$ cation. Several reactions of 1 and $\mathrm{Cp}_{2} \mathrm{MX}^{\prime} \mathrm{X}^{\text {“" }}\left(\mathrm{M}=\mathrm{Ti}, \mathrm{Zr} ; \mathrm{X}^{\prime}, \mathrm{X}^{\prime \prime}=\mathrm{Me}, \mathrm{Cl}, \mathrm{F}\right)$ are described although no characterized products or structures of these composites are available [53].

The reaction between 1 and $\mathrm{Cp}_{2} \mathrm{ZrMeF}$ yielded compound 7 (Figure 1, Table 1) as expected. $\mathrm{Cp}_{2} \mathrm{ZrMeF}$ was prepared in situ using $\mathrm{Cp}_{2} \mathrm{ZrMe}_{2}$ and $\mathrm{Me}_{3} \mathrm{SnF}$ (Scheme 3). Attempts to grow X-ray quality crystals of 7 from toluene/ $h$ hexane mixtures $(5: 1)$ were unsuccessful. Crystallization from a THF/toluene/nhexane $(1: 8: 2)$ solution of 7 produced X-ray quality crystals at $-20{ }^{\circ} \mathrm{C}$ after 4 weeks.

$$
\begin{array}{lll}
\mathrm{Cp}_{2} \mathrm{ZrMe}_{2}+\mathrm{Me}_{3} \mathrm{SnF} & \longrightarrow \mathrm{Cp}_{2} \mathrm{ZrMeF}+\mathrm{Me}_{4} \mathrm{Sn} \\
{\left[\left(\mathrm{Me}_{3} \mathrm{Si}_{3}\right)_{3} \mathrm{CAlF}_{2}\right]_{3}+3 \mathrm{Cp}_{2} \mathrm{ZrMeF}} & \longrightarrow 3\left[\mathrm{Cp}_{2} \mathrm{ZrMe}\right](\mu-\mathrm{F})\left[\mathrm{F}_{2} \mathrm{AlC}\left(\mathrm{SiMe}_{3}\right)_{3}\right]
\end{array}
$$

Scheme 3

However, these crystals proved to be $\left[\mathrm{Cp}_{2} \mathrm{Zr}(\mu-\mathrm{F})_{2} \mathrm{FAlC}\left(\mathrm{SiMe}_{3}\right)_{3}\right]_{2} \mathrm{O}$ (8) (Figure 2, Table 2, Scheme 4). Presumably the source of the oxygen atom can be considered either oxygen, water or presumably THF since group 13 Lewis acids are known to cleave aliphatic ethers [54-59]. The opening of the THF molecule and its coordination to aluminum was recently shown by an 
X-ray structural analysis of its product [59]. The condensation of two molecules of 7 with elimination of the methyl groups and formation of the $\mu$-oxygen bridge in $\mathbf{8}$ is the second step of this reaction. A comparable eight-membered $\mathrm{Al}_{2} \mathrm{~F}_{4} \mathrm{Zr}_{2}$ ring-system is found in cis$\left[\mathrm{Cp} * \mathrm{ZrMe}(\mu-\mathrm{F})(\mu-\mathrm{F})_{2} \mathrm{AlMe}_{2}\right]_{2}$ (f). However, in the latter compound the zirconium atoms are bridged by two $\mu$-F units [37]. Compound $\mathbf{8}$ is insoluble in THF or toluene. A second attempt to produce compound $\mathbf{8}$ under the same conditions resulted in the formation of a $2: 1$ mixture of compounds 7 and $\mathbf{8}$.

$\left[\mathrm{Cp}_{2} \mathrm{ZrMe}\right](\mu-\mathrm{F})\left[\mathrm{F}_{2} \mathrm{AlC}\left(\mathrm{SiMe}_{3}\right)_{3}\right]+\mathrm{THF}$

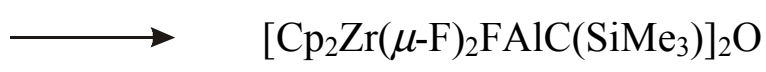

8

\section{Scheme 4}

Compound 7 decomposes slowly at $200{ }^{\circ} \mathrm{C}$.

The elemental analysis of $\mathbf{7}$ for $\mathrm{C}$ and $\mathrm{H}$ confirms the required composition of $\mathrm{C}_{21} \mathrm{H}_{40} \mathrm{AlF}_{3} \mathrm{Si}_{3} \mathrm{Zr}$.

The ${ }^{1} \mathrm{H}$ NMR spectrum of 7 shows resonances of the protons for the zirconium bound methyl group at $\delta 0.56 \mathrm{ppm}$ which is $0.04 \mathrm{ppm}$ shifted downfield in relation to the comparable methyl group of $c i s-\left[\mathrm{Cp}^{*} \mathrm{ZrMe}(\mu-\mathrm{F})(\mu-\mathrm{F})_{2} \mathrm{AlMe}_{2}\right]_{2}(\mathbf{f})(\delta 0.52 \mathrm{ppm})$ [34]. The resonances of the $\mathrm{Cp}$ protons appear at $\delta 6.36 \mathrm{ppm}$ also shifted downfield compared to $\mathrm{Cp}$-protons of [ $\mathrm{Cp}_{2} \mathrm{ZrMe}$ ]$(\mu-\mathrm{F})\left[\mathrm{Al}\left(\mathrm{C}_{12} \mathrm{~F}_{9}\right)_{3}\right](\delta 5.56 \mathrm{ppm})[52]$.

The ${ }^{19} \mathrm{~F}$ NMR shows signals with the correct ratio $(2: 1)$ at $\delta-165.4 \mathrm{ppm}$ for the terminal aluminum bonded fluorine atoms and at $\delta-161.8 \mathrm{ppm}$ for the aluminum zirconium bridging fluorine atom considerably shifted upfield compared to $\left[\mathrm{Cp}_{2} \mathrm{ZrMe}\right](\mu-\mathrm{F})\left[\mathrm{Al}\left(\mathrm{C}_{12} \mathrm{~F}_{9}\right)_{3}\right]$ $(\delta-138.11 \mathrm{ppm})[52]$. 
The $\mathrm{Zr}\left(1^{\circ}\right)-\mathrm{F}\left(1^{\circ}\right)$ distance $(2.118(2) \AA$ ) in 7 (Figure 1, Table 1) is slightly longer than the Zr-F distances for the bridging fluorine in $\left[\mathrm{Cp}^{*} \mathrm{ZrF}_{3}\right]_{4}(2.121-2.160 \AA)$ [34]. The zirconiumcarbon bond length of the methyl group $\left[\mathrm{Zr}\left(1^{\circ}\right)-\mathrm{C}^{\prime \prime} 2.238(3) \AA\right]$ is comparable to that in $\left[\mathrm{Me}_{2} \mathrm{Si}\left(\eta^{5}-\mathrm{Me}_{4} \mathrm{C}_{5}(t-\mathrm{BuN})\right) \mathrm{ZrMe}\right]^{+}\left[\left(\mathrm{C}_{12} \mathrm{~F}_{9}\right)_{3} \mathrm{AlF}\right]^{-}(\mathrm{Zr}-\mathrm{Me} 2.21 \AA)$ [52]. The Al-F(bridging) $\left(\mathrm{Al}\left(1^{\circ}\right)-\mathrm{F}\left(1^{\circ}\right) 1.779(2) \AA\right)$ distance in 7 is also similar to the Al-F(bridging) distance in $\left[\mathrm{Me}_{2} \mathrm{Si}\left(\eta^{5}-\mathrm{Me}_{4} \mathrm{C}_{5}(t-\mathrm{BuN})\right) \mathrm{ZrMe}\right]^{+}\left[\left(\mathrm{C}_{12} \mathrm{~F}_{9}\right)_{3} \mathrm{AlF}\right]^{-}(1.780 \AA)$ [52].

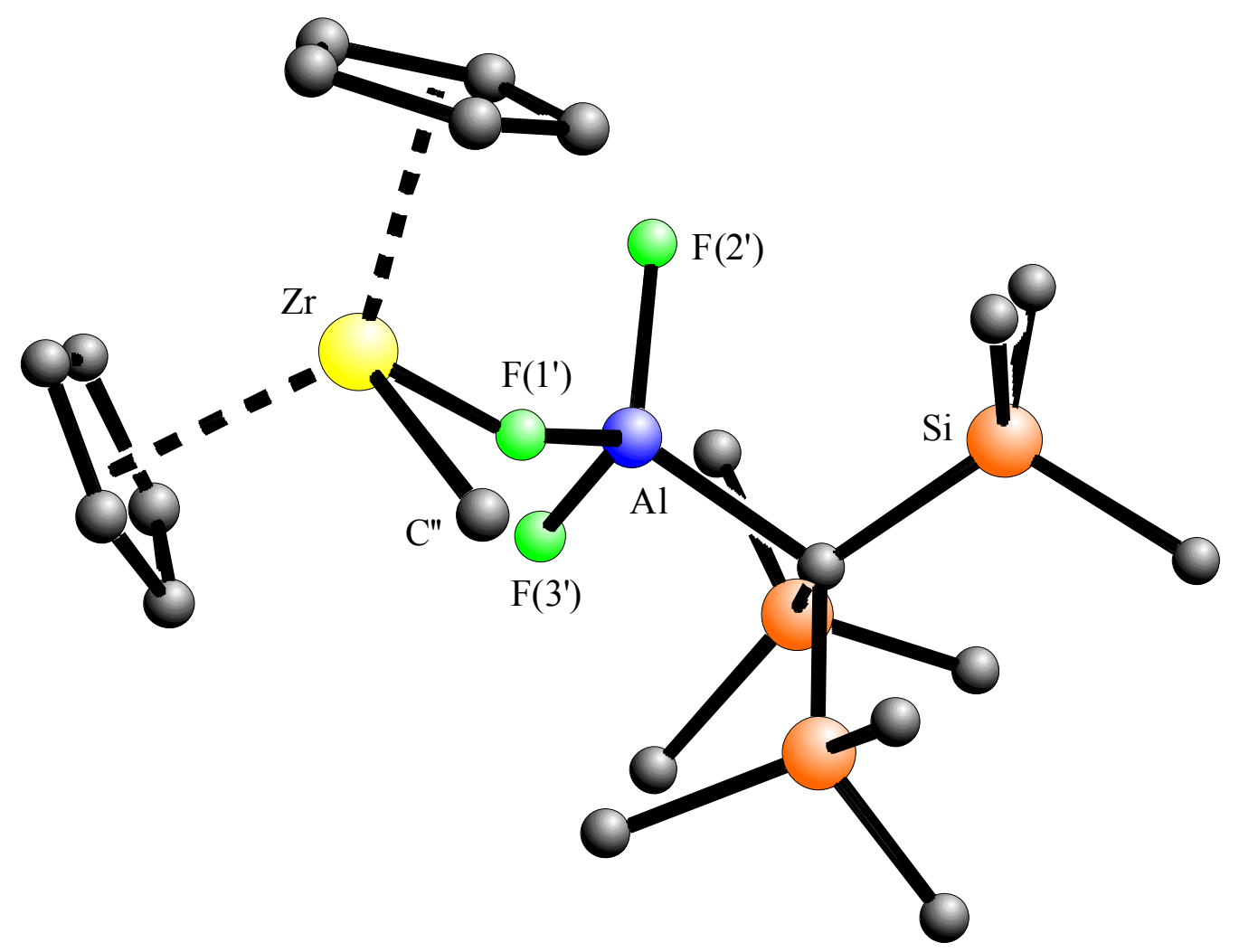

Figure 1. Molecular structure of $\left[\mathrm{Cp}_{2} \mathrm{ZrMe}\right](\mu-\mathrm{F})\left[\mathrm{F}_{2} \mathrm{AlC}\left(\mathrm{SiMe}_{3}\right)_{3}\right](7)$.

Table 1. Selected bond lengths ( $\AA$ ) and angles (deg) for 7.

$\begin{array}{llll}\mathrm{Al}\left(1^{\circ}\right)-\mathrm{F}\left(1^{`}\right) & 1.779(2) & \mathrm{Zr}\left(1^{\circ}\right)-\mathrm{F}\left(1^{`}\right) & 2.118(2) \\ \mathrm{Al}\left(1^{\circ}\right)-\mathrm{F}\left(2^{`}\right) & 1.674(2) & \mathrm{Zr}\left(1^{\circ}\right)-\mathrm{C}^{\circ \triangleleft} & 2.238(3) \\ \mathrm{Al}\left(1^{\circ}\right)-\mathrm{F}\left(3^{`}\right) & 1.678(2) & \mathrm{Al}\left(1^{\circ}\right)-\mathrm{C}\left(61^{`}\right) & 1.965(3)\end{array}$




\begin{tabular}{|c|c|c|c|}
\hline $\mathrm{F}\left(1^{\circ}\right)-\mathrm{Al}\left(1^{\circ}\right)-\mathrm{F}\left(2^{\circ}\right)$ & $100.86(10)$ & $F\left(1^{\circ}\right)-\operatorname{Zr}\left(1^{\circ}\right)-C^{، ‘}$ & $95.52(11)$ \\
\hline $\mathrm{F}\left(2^{\circ}\right)-\mathrm{Al}\left(1^{\circ}\right)-\mathrm{F}\left(3^{\circ}\right)$ & $108.08(12)$ & $\mathrm{F}\left(1^{\circ}\right)-\mathrm{Al}\left(1^{\circ}\right)-\mathrm{C}\left(61^{\circ}\right)$ & $112.48(11)$ \\
\hline $\mathrm{F}\left(1^{\circ}\right)-\mathrm{Al}\left(1^{\circ}\right)-\mathrm{F}\left(3^{\circ}\right)$ & $100.53(10)$ & $\mathrm{F}\left(2^{\circ}\right)-\mathrm{Al}\left(1^{\circ}\right)-\mathrm{C}\left(61^{\circ}\right)$ & $116.62(12)$ \\
\hline $\operatorname{Al}\left(1^{\circ}\right)-\mathrm{F}\left(1^{\circ}\right)-\operatorname{Zr}\left(1^{\circ}\right)$ & $152.00(10)$ & $\mathrm{F}\left(3^{\circ}\right)-\mathrm{Al}\left(1^{\circ}\right)-\mathrm{C}\left(61^{\circ}\right)$ & $116.08(22)$ \\
\hline
\end{tabular}

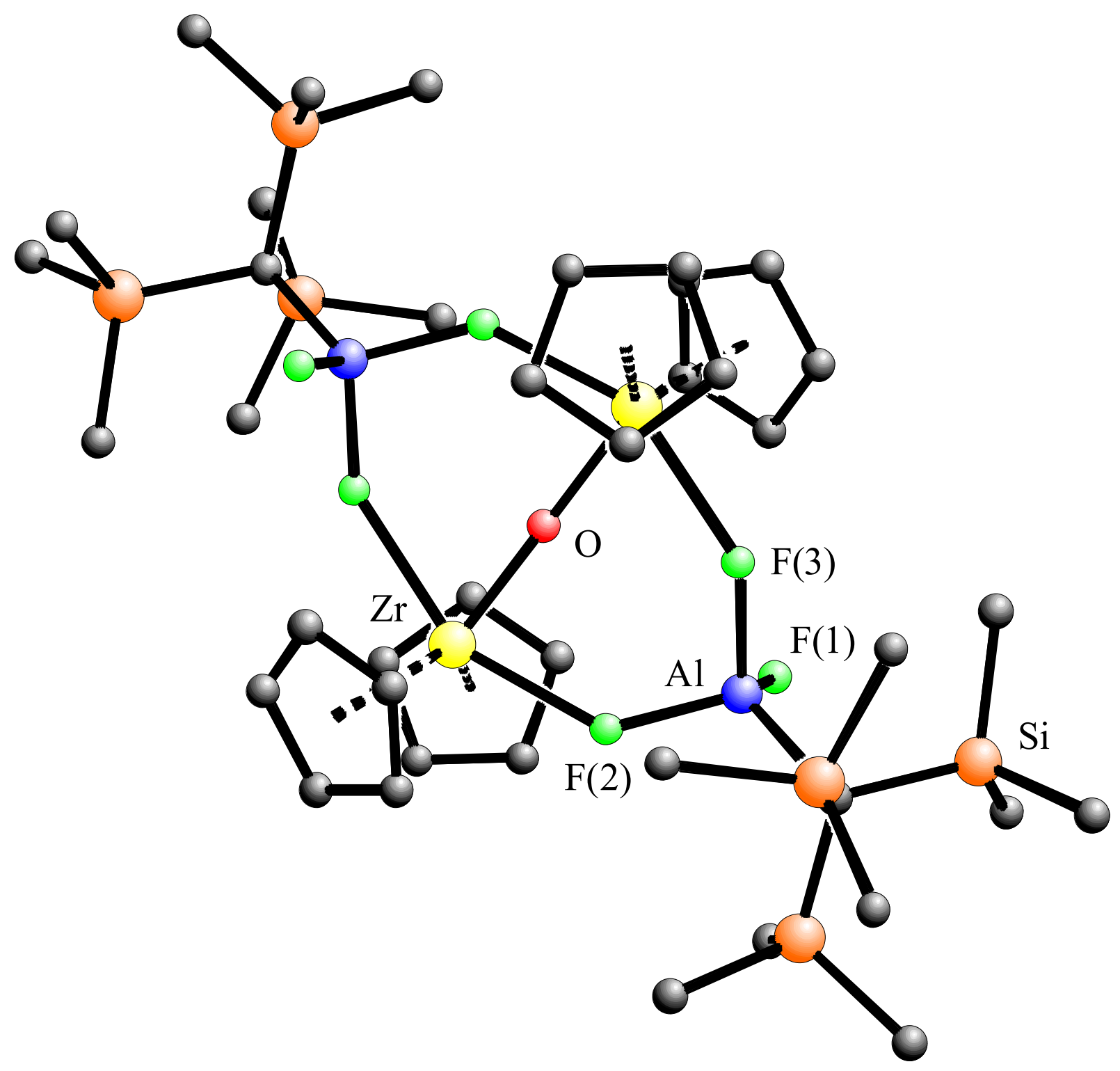

Figure 2. Molecular structure of $\left[\mathrm{Cp}_{2} \mathrm{Zr}(\mu-\mathrm{F})_{2} \mathrm{FAlC}\left(\mathrm{SiMe}_{3}\right)_{3}\right]_{2} \mathrm{O}(\mathbf{8})$. 
The Al-F(terminal) distances (average 1.675 - $1.678 \AA$ ) in 8 (Figure 2, Table 2) are comparable to those Al-F(terminal) in $\left[\left(\mathrm{Me}_{3} \mathrm{Si}_{3}\right)_{3} \mathrm{CAlF}_{2}\right]_{3}[59](1.657-1.671 \AA$ ). The Al$\mathrm{F}$ (bridging) bond lengths $(1.735-1.779 \AA)$ are shorter than those in $\left[\left(\mathrm{Me}_{3} \mathrm{Si}\right)_{3} \mathrm{CAlF}_{2}\right]_{3}[59]$ (1.795 - $1.815 \AA)$ and similar to those in 7. The Zr-F(bridging) distances $(2.312-2.359 \AA)$ in 8 are somewhat longer than those in $7\left(\mathrm{Zr}\left(1^{\circ}\right)-\mathrm{F}\left(1^{\circ}\right) 2.118(2) \AA\right)$.

Table 2. Selected bond lengths $(\AA)$ and angles (deg) for $\mathbf{8}$.

$\begin{array}{llll}\text { Zr\#1-O } & 1.9499(7) & \mathrm{Al}-\mathrm{F}(1) & 1.677(2) \\ \mathrm{Zr-F}(2) \# 1 & 2.312(2) & \mathrm{Al}-\mathrm{F}(2) & 1.743(2) \\ \mathrm{Zr}-\mathrm{F}(3) & 2.359(2) & \mathrm{Al}-\mathrm{F}(3) & 1.735(2) \\ \mathrm{Al}-\mathrm{C}(61) & 1.963(2) & \mathrm{O}-\mathrm{Zr} & 1.9499(7) \\ & & & \\ \mathrm{O}-\mathrm{Zr}-\mathrm{F}(2) \# 1 & 76.48(5) & \mathrm{F}(2)-\mathrm{Al}-\mathrm{C}(61) & 115.31(11) \\ \mathrm{F}(2) \# 1-\mathrm{Zr}-\mathrm{F}(3) & 151.06(6) & \mathrm{Zr}-\mathrm{O}-\mathrm{Zr} \# 1 & 180.0 \\ \mathrm{O}-\mathrm{Zr}-\mathrm{F}(3) & 74.59(5) & \mathrm{F}(1)-\mathrm{Al}(1)-\mathrm{F}(3) & 104.87(9) \\ \mathrm{F}(2)-\mathrm{Al}-\mathrm{F}(3) & 103.56(9) & \mathrm{F}(1)-\mathrm{Al}(1)-\mathrm{F}(2) & 103.87(9) \\ \mathrm{F}(3)-\mathrm{Al}-\mathrm{C}(61) & 114.23(11) & \mathrm{F}(1)-\mathrm{Al}-\mathrm{C}(61) & 113.73(11) \\ \mathrm{Al}-\mathrm{F}(3)-\mathrm{Zr} & 136.59(9) & \mathrm{Al}-\mathrm{F}(2)-\mathrm{Zr} \# 1 & 135.32(9)\end{array}$

2.1.1. Investigations on the Catalytic Activity of 7

The catalytic activity test of ethene polymerization was carried out in a glass reactor $(250 \mathrm{~mL})$ in ethene-saturated $(1 \mathrm{bar})$ toluene $(80 \mathrm{~mL})$ solution at room temperature. $7(0.020 \mathrm{~g}, 36$ mmol), dissolved in toluene $(5 \mathrm{~mL})$, was injected with a syringe. The mixture was stirred while ethene was vigorously bubbled through the solution. After $30 \mathrm{~min}$ the experiment was terminated by interupting the ethene supply and adding ethanol $(10 \mathrm{~mL})$. No formation of polyethene was observed under this condition [43]. 


\subsection{Synthesis of $\left[\mathrm{Na}\left(\mathrm{Me}_{3} \mathrm{Si}\right)_{3} \mathrm{CAIF}_{3}(\mathrm{THF})\right]_{4}(9)$}

Compositions of $\mathbf{1}$ with the alkali metal fluorides $\mathrm{LiF}$ and $\mathrm{KF}$ (5 and 2) [43, 45] are known, although no information about the sodium derivative is available. The direct reaction of $\left(\mathrm{Me}_{3} \mathrm{Si}\right)_{3} \mathrm{CAlF}_{2}$-THF with sodium fluoride failed. This is probably due to the higher lattice energy and the chemical inertness of the latter alkali metal fluoride [2]. The reaction of $\left(\mathrm{Me}_{3} \mathrm{Si}\right)_{3} \mathrm{CAlMe}_{2} \cdot \mathrm{THF}$ with $\mathrm{Me}_{3} \mathrm{SnF}$ and $\mathrm{NaCl}$ affords 9 (Scheme 5). It was necessary to use a threefold excess of the in situ generated sodium fluoride to produce 9. Attempts to reduce the reaction time of 4 days at room temperature failed. Unidentified by-products can be observed when the reaction is interupted after 2 days.

$$
\begin{aligned}
& \left(\mathrm{Me}_{3} \mathrm{Si}\right)_{3} \mathrm{CAlF}_{2} \cdot \mathrm{THF}+\mathrm{NaF}
\end{aligned}
$$

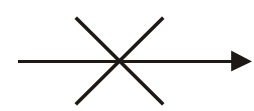

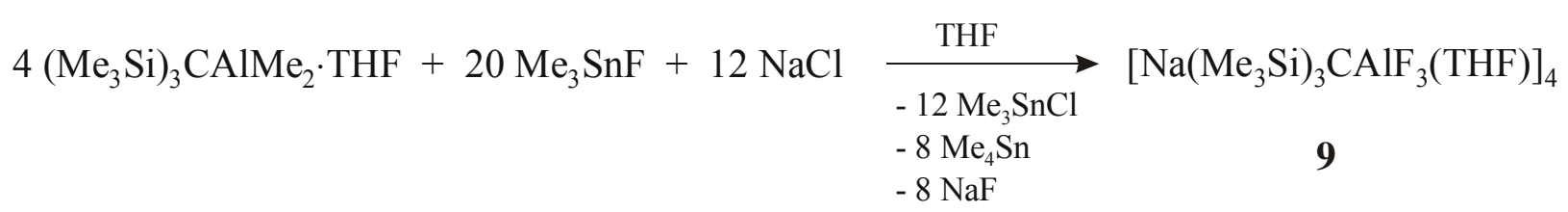

\section{Scheme 5}

The elemental analysis of $\mathbf{9}$ for the elements $\mathrm{C}$ and $\mathrm{H}$ confirms the required composition of $\mathrm{C}_{56} \mathrm{H}_{140} \mathrm{Al}_{4} \mathrm{~F}_{12} \mathrm{Na}_{4} \mathrm{O}_{4} \mathrm{Si}_{12}$ (look at Figure 3 for comments about the composition of the crystals of 9).

The ${ }^{1} \mathrm{H}$ NMR spectrum of 9 shows a singlet for the protons of the trimethylsilyl ligand at $\delta 0.41 \mathrm{ppm}$ as is observed for $\mathbf{5}$. The proton resonances of the coordinated THF molecule appear at $\delta 1.45 \mathrm{ppm}\left(\mathrm{OCH}_{2} \mathrm{CH}_{2}\right)$ and $3.68 \mathrm{ppm}\left(\mathrm{OCH}_{2} \mathrm{CH}_{2}\right)$ which are shifted upfield in comparison to $5(\delta 1.55 \mathrm{ppm})$ for the only carbon bonded methylene protons of THF $\left(\mathrm{OCH}_{2} \mathrm{CH}_{2}\right)$ and shifted downfield $(\delta 3.91 \mathrm{ppm})$ for the oxygen bonded methylene protons of the THF molecule, respectively. 
The expected singlet in the ${ }^{19} \mathrm{~F}$ NMR spectrum is observed at $\delta-176.7 \mathrm{ppm}$ for the fluorine atoms of the $\left[\left(\mathrm{Me}_{3} \mathrm{Si}_{3} \mathrm{CAlF}_{3}\right]^{-}\right.$anion.

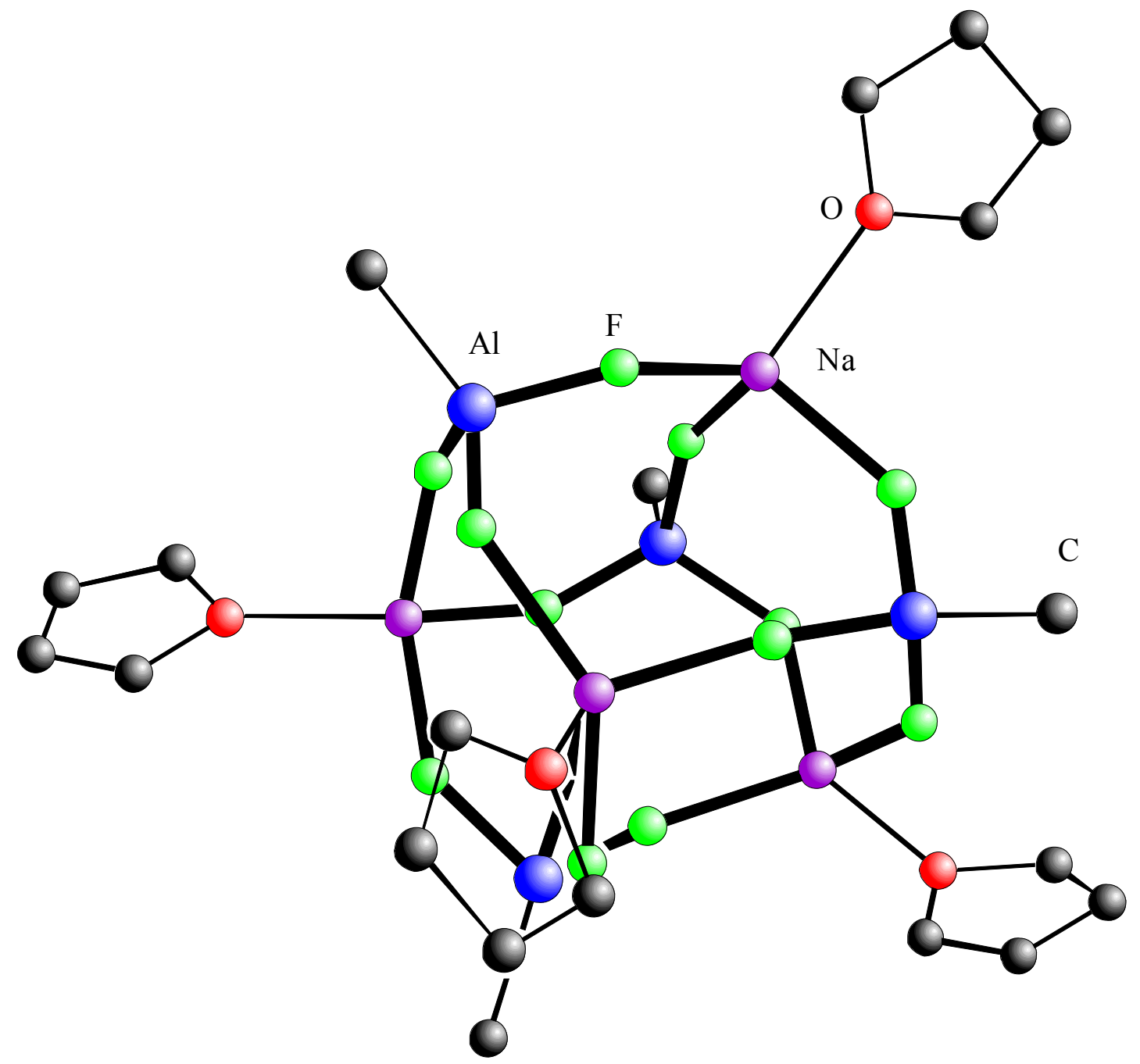

Figure 3. Molecular structure of $\left[\mathrm{Na}\left(\mathrm{Me}_{3} \mathrm{Si}_{3}\right)_{3} \mathrm{CAlF}_{3}(\mathrm{THF})\right]_{4}(\mathbf{9})$. $\mathrm{Me}_{3} \mathrm{Si}$ groups are omitted for clarity. One of the THF molecules represents a position that is only $50 \%$ occupied by THF to form $\left[\mathrm{Na}\left(\mathrm{Me}_{3} \mathrm{Si}\right)_{3} \mathrm{CAlF}_{3}(\mathrm{THF})\right]_{4}$. The other $50 \%$ of this position is occupied by a toluene molecule to form $\left[\left\{\mathrm{Na}\left(\mathrm{Me}_{3} \mathrm{Si}\right)_{3} \mathrm{CAlF}_{3}\right\}_{4}(\mathrm{THF})_{3}(\right.$ toluene $\left.)\right]$. Figure 3 shows only the $\mathrm{THF}$ molecule.

Crystals of 9 suitable for X-ray structural investigations were obtained from toluene/nhexane (5:1) at $-20^{\circ} \mathrm{C}$. Compound 9 (Figure 3, Table 3) is isostructural with 5. The structure 
consists of a cube formed of aluminum and sodium atoms alternating at the corners, which are bridged by fluorine atoms. The Na-F distances are in the range of $2.158-2.278 \AA$, which is shorter than in crystalline sodium fluoride (2.303 $\AA$ ) [62]. The Al-F bond distances cover a small range $(1.683-1.703 \AA)$. These are comparable to those in 5 (av $1.687 \AA$ ) but considerably shorter than the Al-F(bridging) distances in 2 (av $1.805 \AA$ ) [43]. The Na-O distances $\left(2.137-2.278 \AA\right.$ ) are similar to those in $\left[\mathrm{Cp}^{*}{ }_{6} \mathrm{Ti}_{6} \mathrm{Na}_{7} \mathrm{~F}_{19}(2.5 \mathrm{THF})\right](2.291-2.319 \AA)$ [63] but slightly shorter than those in $\left[\mathrm{Na}_{4} \mathrm{Bi}_{2}\left(\mu_{6}-\mathrm{O}\right)\left(\mathrm{OC}_{6} \mathrm{~F}_{5}\right)_{8}(\mathrm{THF})_{4}\right](2.326-2.496 \AA)$ [64].

Table 3. Selected bond lengths $(\AA)$ and angles (deg) for $\mathbf{9}$.

\begin{tabular}{|c|c|c|c|}
\hline $\mathrm{Al}(1)-\mathrm{F}(1)$ & $1.693(3)$ & $\mathrm{F}(3)-\mathrm{Na}(2)$ & $2.156(3)$ \\
\hline $\mathrm{Al}(1)-\mathrm{F}(5)$ & $1.692(3)$ & $\mathrm{F}(4)-\mathrm{Na}(1)$ & $2.172(4)$ \\
\hline $\mathrm{Al}(1)-\mathrm{F}(2)$ & $1.683(3)$ & $\mathrm{F}(5)-\mathrm{Na}(4)$ & $2.220(4)$ \\
\hline $\mathrm{Al}(1)-\mathrm{C}(1)$ & $1.959(5)$ & $\mathrm{F}(6)-\mathrm{Na}(2)$ & $2.158(3)$ \\
\hline $\operatorname{Al}(3)-F(8)$ & $1.703(4)$ & $\mathrm{F}(7)-\mathrm{Na}(2)$ & $2.179(3)$ \\
\hline $\operatorname{Al}(3)-F(9)$ & $1.687(3)$ & $\mathrm{F}(8)-\mathrm{Na}(1)$ & $2.169(4)$ \\
\hline $\operatorname{Al}(3)-F(10)$ & $1.684(4)$ & $\mathrm{F}(9)-\mathrm{Na}(4)$ & $2.208(3)$ \\
\hline $\mathrm{Al}(3)-\mathrm{C}(21)$ & $1.968(5)$ & $\mathrm{F}(10)-\mathrm{Na}(3)$ & $2.205(4)$ \\
\hline $\operatorname{Al}(4)-F(6)$ & $1.702(5)$ & $\mathrm{F}(11)-\mathrm{Na}(3)$ & $2.173(3)$ \\
\hline $\mathrm{Al}(4)-\mathrm{F}(11)$ & $1.682(3)$ & $\mathrm{F}(12)-\mathrm{Na}(4)$ & $2.278(5)$ \\
\hline $\mathrm{Al}(4)-\mathrm{F}(12)$ & $1.694(3)$ & $\mathrm{Na}(1)-\mathrm{O}(1)$ & $2.278(5)$ \\
\hline $\mathrm{Al}(4)-\mathrm{C}(31)$ & $1.963(5)$ & $\mathrm{Na}(2)-\mathrm{O}(2)$ & $2.278(4)$ \\
\hline $\mathrm{F}(1)-\mathrm{Na}(1)$ & $2.166(3)$ & $\mathrm{Na}(3)-\mathrm{O}(3)$ & $2.210(5)$ \\
\hline $\mathrm{F}(2)-\mathrm{Na}(2)$ & $2.158(3)$ & $\mathrm{Na}(4)-\mathrm{O}(4)$ & $2.137(7)$ \\
\hline $\mathrm{F}(2)-\mathrm{Al}(1)-\mathrm{F}(5)$ & $104.1(2)$ & $\mathrm{Al}(1)-\mathrm{F}(1)-\mathrm{Na}(1)$ & $144.0(2)$ \\
\hline $\mathrm{F}(2)-\mathrm{Al}(1)-\mathrm{F}(1)$ & $105.5(2)$ & $\mathrm{Al}(1)-\mathrm{F}(2)-\mathrm{Na}(2)$ & $152.3(2)$ \\
\hline $\mathrm{F}(1)-\mathrm{Al}(1)-\mathrm{F}(5)$ & $105.4(2)$ & $\mathrm{Al}(2)-\mathrm{F}(3)-\mathrm{Na}(2)$ & $148.4(2)$ \\
\hline
\end{tabular}




\begin{tabular}{|c|c|c|c|}
\hline $\mathrm{F}(2)-\mathrm{Al}(1)-\mathrm{C}(1)$ & $113.2(2)$ & $\mathrm{Al}(2)-\mathrm{F}(4)-\mathrm{Na}(1)$ & $149.6(2)$ \\
\hline $\mathrm{F}(5)-\mathrm{Al}(1)-\mathrm{C}(1)$ & $115.3(2)$ & $\mathrm{Al}(1)-\mathrm{F}(5)-\mathrm{Na}(4)$ & $137.3(2)$ \\
\hline $\mathrm{F}(1)-\mathrm{Al}(1)-\mathrm{C}(1)$ & $112.5(2)$ & $\mathrm{Al}(4)-\mathrm{F}(6)-\mathrm{Na}(2)$ & $139.7(2)$ \\
\hline $\mathrm{F}(3)-\mathrm{Al}(2)-\mathrm{F}(4)$ & $105.4(2)$ & $\mathrm{Al}(2)-\mathrm{F}(7)-\mathrm{Na}(3)$ & $134.8(2)$ \\
\hline $\mathrm{F}(3)-\mathrm{Al}(2)-\mathrm{F}(7)$ & $104.1(2)$ & $\mathrm{Al}(3)-\mathrm{F}(8)-\mathrm{Na}(1)$ & $142.4(2)$ \\
\hline $\mathrm{F}(4)-\mathrm{Al}(2)-\mathrm{F}(7)$ & $103.9(2)$ & $\mathrm{Al}(3)-\mathrm{F}(9)-\mathrm{Na}(4)$ & $157.5(2)$ \\
\hline $\mathrm{F}(3)-\mathrm{Al}(2)-\mathrm{C}(11)$ & $112.8(2)$ & $\mathrm{Al}(3)-\mathrm{F}(10)-\mathrm{Na}(3)$ & $127.4(2)$ \\
\hline $\mathrm{F}(4)-\mathrm{Al}(2)-\mathrm{C}(11)$ & $113.9(2)$ & $\mathrm{Al}(4)-\mathrm{F}(11)-\mathrm{Na}(3)$ & $167.7(2)$ \\
\hline $\mathrm{F}(7)-\mathrm{Al}(2)-\mathrm{C}(11)$ & $115.7(2)$ & $\mathrm{Al}(4)-\mathrm{F}(12)-\mathrm{Na}(4)$ & $139.6(2)$ \\
\hline $\mathrm{F}(8)-\mathrm{Al}(3)-\mathrm{F}(10)$ & $102.3(2)$ & $\mathrm{F}(1)-\mathrm{Na}(1)-\mathrm{F}(8)$ & $99.8(1)$ \\
\hline $\mathrm{F}(9)-\mathrm{Al}(3)-\mathrm{F}(10)$ & $105.3(2)$ & $\mathrm{F}(1)-\mathrm{Na}(1)-\mathrm{F}(4)$ & $106.4(1)$ \\
\hline $\mathrm{F}(8)-\mathrm{Al}(3)-\mathrm{F}(9)$ & $105.5(2)$ & $\mathrm{F}(8)-\mathrm{Na}(1)-\mathrm{F}(4)$ & $105.6(2)$ \\
\hline $\mathrm{F}(10)-\mathrm{Al}(3)-\mathrm{C}(21)$ & $114.9(2)$ & $\mathrm{F}(1)-\mathrm{Na}(1)-\mathrm{O}(1)$ & $120.9(2)$ \\
\hline $\mathrm{F}(9)-\mathrm{Al}(3)-\mathrm{C}(21)$ & $113.1(2)$ & $\mathrm{F}(8)-\mathrm{Na}(1)-\mathrm{O}(1)$ & $112.1(2)$ \\
\hline $\mathrm{F}(8)-\mathrm{Al}(3)-\mathrm{C}(21)$ & $114.6(2)$ & $\mathrm{F}(4)-\mathrm{Na}(1)-\mathrm{O}(1)$ & $110.6(2)$ \\
\hline $\mathrm{F}(11)-\mathrm{Al}(4)-\mathrm{F}(12)$ & $105.1(2)$ & $\mathrm{F}(3)-\mathrm{Na}(2)-\mathrm{F}(2)$ & $102.6(1)$ \\
\hline $\mathrm{F}(11)-\mathrm{Al}(4)-\mathrm{F}(6)$ & $104.3(2)$ & $\mathrm{F}(3)-\mathrm{Na}(2)-\mathrm{F}(6)$ & $105.6(1)$ \\
\hline $\mathrm{F}(12)-\mathrm{Al}(4)-\mathrm{F}(6)$ & $103.9(2)$ & $\mathrm{F}(2)-\mathrm{Na}(2)-\mathrm{F}(6)$ & 111.1(1) \\
\hline $\mathrm{F}(11)-\mathrm{Al}(4)-\mathrm{C}(31)$ & $113.5(2)$ & $\mathrm{F}(3)-\mathrm{Na}(2)-\mathrm{O}(2)$ & $126.1(2)$ \\
\hline $\mathrm{F}(12)-\mathrm{Al}(4)-\mathrm{C}(31)$ & $115.3(2)$ & $\mathrm{F}(2)-\mathrm{Na}(2)-\mathrm{O}(2)$ & $112.7(2)$ \\
\hline $\mathrm{F}(6)-\mathrm{Al}(4)-\mathrm{C}(31)$ & $113.5(2)$ & $\mathrm{F}(6)-\mathrm{Na}(2)-\mathrm{O}(2)$ & $98.3(2)$ \\
\hline $\mathrm{F}(11)-\mathrm{Na}(3)-\mathrm{F}(7)$ & $108.0(1)$ & $\mathrm{O}(4)-\mathrm{Na}(4)-\mathrm{F}(9)$ & $119.0(2)$ \\
\hline $\mathrm{F}(11)-\mathrm{Na}(3)-\mathrm{F}(10)$ & $96.0(1)$ & $\mathrm{O}(4)-\mathrm{Na}(4)-\mathrm{F}(5)$ & $107.4(2)$ \\
\hline $\mathrm{F}(7)-\mathrm{Na}(3)-\mathrm{F}(10)$ & $130.7(2)$ & $\mathrm{F}(9)-\mathrm{Na}(4)-\mathrm{F}(5)$ & $101.0(1)$ \\
\hline $\mathrm{F}(11)-\mathrm{Na}(3)-\mathrm{O}(3)$ & $121.0(2)$ & $\mathrm{O}(4)-\mathrm{Na}(4)-\mathrm{F}(12)$ & $109.7(2)$ \\
\hline $\mathrm{F}(7)-\mathrm{Na}(3)-\mathrm{O}(3)$ & $102.9(2)$ & $\mathrm{F}(9)-\mathrm{Na}(4)-\mathrm{F}(12)$ & $105.3(1)$ \\
\hline $\mathrm{F}(10)-\mathrm{Na}(3)-\mathrm{O}(3)$ & $100.3(2)$ & $\mathrm{F}(5)-\mathrm{Na}(4)-\mathrm{F}(12)$ & $114.6(2)$ \\
\hline
\end{tabular}




\subsection{Synthesis of $\left[\left\{\left(\mathrm{Me}_{3} \mathrm{Si}\right)_{3} \mathrm{CAIF}_{2}\right\}_{2}(\mu-\mathrm{O}) \mathrm{Li}_{2}(\mathrm{THF})_{4}\right](10)$}

There are only a few examples of aluminum fluorine oxygen clusters reported in the literature [58]. The combination of $\left(\mathrm{Me}_{3} \mathrm{Si}\right)_{3} \mathrm{CAlF}_{2} \cdot \mathrm{THF}$ with lithium oxide was anticipated to give new interesting aluminum fluorine-oxygen clusters. Therefore $\left(\mathrm{Me}_{3} \mathrm{Si}\right)_{3} \mathrm{CAlF}_{2} \cdot \mathrm{THF}$ was treated with lithium oxide in THF. A more convenient route to $\mathbf{1 0}$ is the in situ generation of $\left(\mathrm{Me}_{3} \mathrm{Si}\right)_{3} \mathrm{CAlF}_{2}$. THF by the action of $\mathrm{Me}_{3} \mathrm{SnF}$ with $\left(\mathrm{Me}_{3} \mathrm{Si}\right)_{3} \mathrm{CAlMe}$. THF in the presence of lithium oxide (Figure 4, Table 4, Scheme 6).

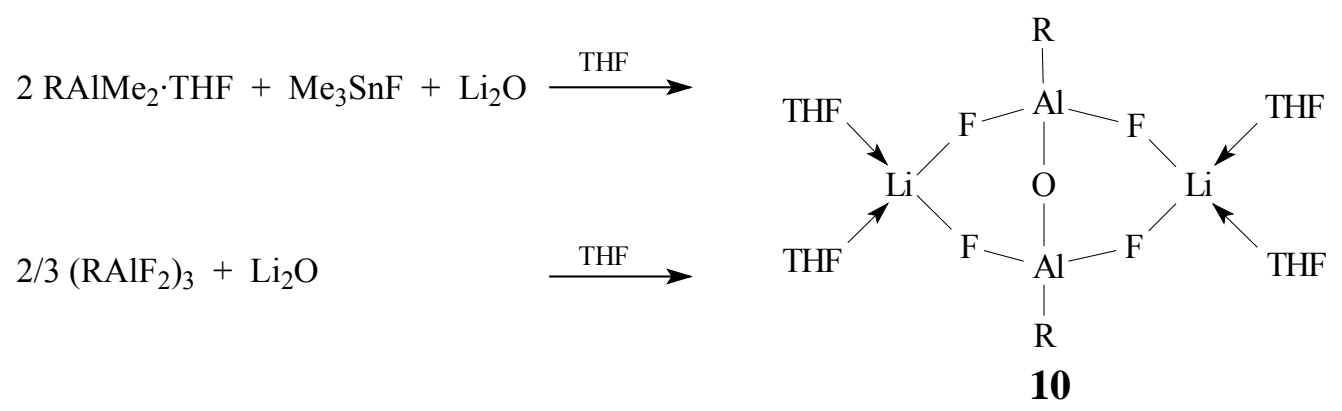

Scheme 6. $\mathrm{R}=\mathrm{C}\left(\mathrm{SiMe}_{3}\right)_{3}$. The two routes to generate $\mathbf{1 0}$.

The elemental analysis of $\mathbf{1 0}$ for the elements $\mathrm{C}$ and $\mathrm{H}$ confirms the required composition of $\mathrm{C}_{36} \mathrm{H}_{86} \mathrm{Al}_{2} \mathrm{~F}_{4} \mathrm{Li}_{2} \mathrm{O}_{5} \mathrm{Si}_{6}$.

The ${ }^{1} \mathrm{H}$ NMR spectrum shows a singlet for the protons of the trimethylsilyl ligand at $\delta 0.43$ ppm only slightly shifted downfield compared to 5 ( $\delta 0.41 \mathrm{ppm})$. The resonances of the protons of the coordinated THF molecule appear at $\delta 0.90 \mathrm{ppm}\left(\mathrm{OCH}_{2} \mathrm{CH}_{2}\right)$ and $3.79 \mathrm{ppm}$ $\left(\mathrm{OCH}_{2} \mathrm{CH}_{2}\right)$.

The ${ }^{19} \mathrm{~F}$ NMR spectrum shows only one signal for the fluorine atoms at $\delta$-158.5 ppm. 


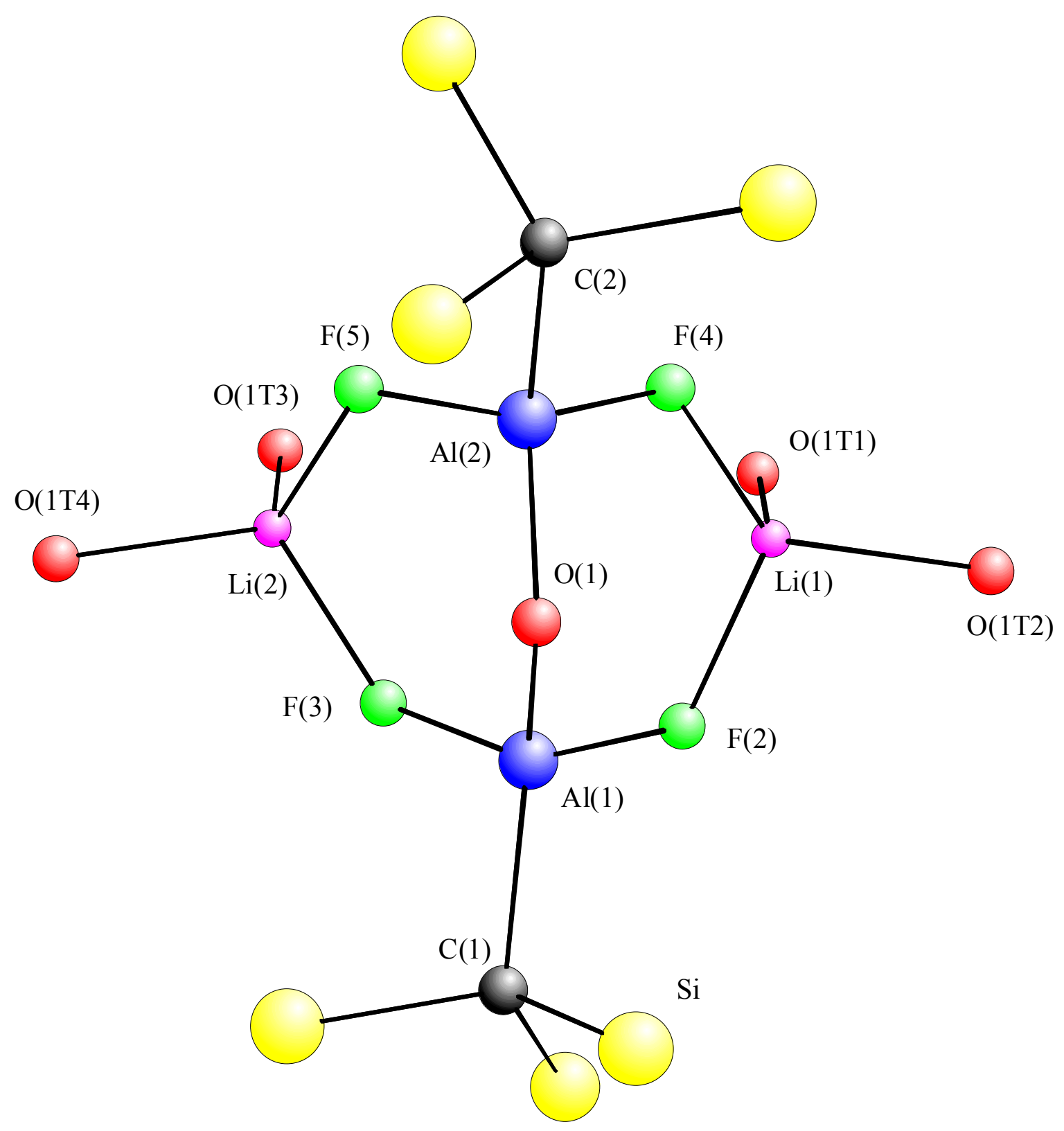

Figure 4. Molecular structure of $\left[\left\{\left(\mathrm{Me}_{3} \mathrm{Si}_{3}\right)_{3} \mathrm{CAlF}_{2}\right\}_{2}(\mu-\mathrm{O}) \mathrm{Li}_{2}(\mathrm{THF})_{4}\right](\mathbf{1 0})$. Me groups are omitted for clarity. Only the ipso oxygens atom of THF are displayed.

Table 4. Selected Bond Lengths $(\AA)$ and Angles (deg) for $\mathbf{1 0 .}$

$\begin{array}{llll}\mathrm{Al}(1)-\mathrm{O}(1) & 1.7083(18) & \mathrm{Li}(1)-\mathrm{F}(2) & 1.854(4) \\ \mathrm{Al}(1)-\mathrm{F}(2) & 1.7373(15) & \mathrm{Li}(1)-\mathrm{F}(4) & 1.837(5) \\ \mathrm{Al}(1)-\mathrm{F}(3) & 1.7316(15) & \mathrm{Li}(2)-\mathrm{F}(3) & 1.850(5)\end{array}$




\begin{tabular}{|c|c|c|c|}
\hline $\mathrm{Al}(1)-\mathrm{C}(1)$ & $1.994(2)$ & $\operatorname{Li}(2)-F(5)$ & $1.835(5)$ \\
\hline $\mathrm{Al}(2)-\mathrm{C}(2)$ & $2.004(3)$ & $\mathrm{Li}(1)-\mathrm{O}(1 \mathrm{~T} 1)$ & $1.948(5)$ \\
\hline $\mathrm{Al}(2)-\mathrm{O}(1)$ & $1.7097(17)$ & $\mathrm{Li}(1)-\mathrm{O}(1 \mathrm{~T} 2)$ & $1.974(5)$ \\
\hline $\operatorname{Al}(2)-F(4)$ & $1.7356(16)$ & $\mathrm{Li}(2)-\mathrm{O}(1 \mathrm{~T} 3)$ & $1.946(5)$ \\
\hline $\operatorname{Al}(2)-F(5)$ & $1.7294(16)$ & $\mathrm{Li}(2)-\mathrm{O}(1 \mathrm{~T} 4)$ & $1.938(5)$ \\
\hline $\mathrm{O}(1)-\mathrm{Al}(1)-\mathrm{F}(3)$ & $107.10(8)$ & $\mathrm{F}(4)-\mathrm{Li}(1)-\mathrm{O}(1 \mathrm{~T} 2)$ & $120.0(2)$ \\
\hline $\mathrm{O}(1)-\mathrm{Al}(1)-\mathrm{F}(2)$ & $106.14(8)$ & $\mathrm{F}(2)-\mathrm{Li}(1)-\mathrm{O}(1 \mathrm{~T} 2)$ & $106.5(2)$ \\
\hline $\mathrm{F}(3)-\mathrm{Al}(1)-\mathrm{F}(2)$ & $100.71(8)$ & $\mathrm{O}(1 \mathrm{~T} 1)-\mathrm{Li}(1)-\mathrm{O}(1 \mathrm{~T} 2)$ & $101.6(2)$ \\
\hline $\mathrm{O}(1)-\mathrm{Al}(1)-\mathrm{C}(1)$ & $120.75(10)$ & $\mathrm{F}(5)-\mathrm{Li}(2)-\mathrm{F}(3)$ & $106.6(2)$ \\
\hline $\mathrm{F}(3)-\mathrm{Al}(1)-\mathrm{C}(1)$ & 109.17(9) & $\mathrm{F}(5)-\mathrm{Li}(2)-\mathrm{O}(1 \mathrm{~T} 4)$ & 117.1(3) \\
\hline $\mathrm{F}(2)-\mathrm{Al}(1)-\mathrm{C}(1)$ & $111.06(10)$ & $\mathrm{F}(3)-\mathrm{Li}(2)-\mathrm{O}(1 \mathrm{~T} 4)$ & $113.6(3)$ \\
\hline $\mathrm{O}(1)-\mathrm{Al}(2)-\mathrm{F}(5)$ & $106.48(8)$ & $\mathrm{F}(5)-\mathrm{Li}(2)-\mathrm{O}(1 \mathrm{~T} 3)$ & $109.6(3)$ \\
\hline $\mathrm{O}(1)-\mathrm{Al}(2)-\mathrm{F}(4)$ & $105.08(8)$ & $\mathrm{F}(3)-\mathrm{Li}(2)-\mathrm{O}(1 \mathrm{~T} 3)$ & $110.1(3)$ \\
\hline $\mathrm{F}(5)-\mathrm{Al}(2)-\mathrm{F}(4)$ & $102.50(8)$ & $\mathrm{O}(1 \mathrm{~T} 4)-\mathrm{Li}(2)-\mathrm{O}(1 \mathrm{~T} 3)$ & $99.7(2)$ \\
\hline $\mathrm{O}(1)-\mathrm{Al}(2)-\mathrm{C}(2)$ & $122.34(10)$ & $\mathrm{Al}(1)-\mathrm{O}(1)-\mathrm{Al}(2)$ & $125.45(10)$ \\
\hline $\mathrm{F}(5)-\mathrm{Al}(2)-\mathrm{C}(2)$ & $109.32(9)$ & $\mathrm{Al}(1)-\mathrm{F}(2)-\mathrm{Li}(1)$ & $120.60(15)$ \\
\hline $\mathrm{F}(4)-\mathrm{Al}(2)-\mathrm{C}(2)$ & $109.31(9)$ & $\mathrm{Al}(1)-\mathrm{F}(3)-\mathrm{Li}(2)$ & $128.51(17)$ \\
\hline $\mathrm{F}(4)-\mathrm{Li}(1)-\mathrm{F}(2)$ & $112.6(2)$ & $\mathrm{Al}(2)-\mathrm{F}(4)-\mathrm{Li}(1)$ & $124.49(15)$ \\
\hline $\mathrm{F}(4)-\mathrm{Li}(1)-\mathrm{O}(1 \mathrm{~T} 1)$ & $103.9(2)$ & $\mathrm{Al}(2)-\mathrm{F}(5)-\mathrm{Li}(2)$ & $126.64(17)$ \\
\hline $\mathrm{F}(2)-\mathrm{Li}(1)-\mathrm{O}(1 \mathrm{~T} 1)$ & $111.5(2)$ & & \\
\hline
\end{tabular}

The structure of $\mathbf{1 0}$ consists of an eight-membered (Al-F-Li-F) $)_{2}$ ring with a transannular Al$\mathrm{O}-\mathrm{Al}$ bridge. The Li-F bond lengths are in the range of $1.835(5)$ to $1.854(4) \AA$ and comparable to the mean Li-F distances $(1.852 \AA)$ in $\left[\mathrm{Li}\left(\mathrm{Me}_{3} \mathrm{Si}_{3}\right)_{3} \mathrm{CAlF}_{3}(\mathrm{THF})\right]_{4}(\mathbf{5})$. The average Al-F bond length $(1.733 \AA)$ in $\mathbf{1 0}$ is slightly shorter than those in $\left[\mathrm{Cp}_{2} \mathrm{ZrMe}\right](\mu$-F)$\left[\mathrm{F}_{2} \mathrm{AlC}\left(\mathrm{SiMe}_{3}\right)_{3}\right]$ (bridging 1.779(2) $\AA$ ). The Al-O distance (av $1.709 \AA$ ) is shorter than those in $\left[\left\{\left(\mathrm{Me}_{3} \mathrm{Si}\right)_{3} \mathrm{CAl}\right\}_{4}(\mu-\mathrm{O})_{2}(\mu-\mathrm{OH})_{4}\right](1.79 \AA)$ [65]. The C-Al-F angle $\left(109.17(9)-111.06(10)^{\circ}\right)$ 
is narrower than those in $\mathbf{5}\left(111.9-115.2^{\circ}\right)$. Obviously, due to a lesser steric influence in $\mathbf{1 0}$ the angles at fluorine are in the range of $120.60(15)-128.51(17)^{\circ}$ and much narrower than those at fluorine in $5\left(140.0-162.9^{\circ}\right)$. The O-Al-F angles in $\mathbf{1 0}\left(105.08(8)-107.10(8)^{\circ}\right)$ differ significantly from those in $\left[\left\{\mathrm{C}\left(\mathrm{CH}_{2} \mathrm{COOEt}\right)_{2}-(\mathrm{COOEt})\right\} \mathrm{OAlFMe}\right]_{2}\left(127.7^{\circ}\right.$ and $\left.90.7-96.8^{\circ}\right)$ [66].

The $\left[\left(\mathrm{Me}_{3} \mathrm{Si}\right)_{3} \mathrm{CAlF}_{2}(\mu-\mathrm{O}) \mathrm{F}_{2} \mathrm{AlC}\left(\mathrm{SiMe}_{3}\right)_{3}\right]$ species in $\mathbf{1 0}$ is comparable to the $\left[\left(\mathrm{Me}_{3} \mathrm{Si}_{3}\right)_{3} \mathrm{CAlF}_{2}(\mu-\mathrm{F}) \mathrm{F}_{2} \mathrm{AlC}\left(\mathrm{SiMe}_{3}\right)_{3}\right]$ part in $\mathbf{2}, \mathbf{3}$, and $\mathbf{4}$, where two of these units coordinate to a metal center. The $\left[\left(\mathrm{Me}_{3} \mathrm{Si}\right)_{3} \mathrm{CAlF}_{2}(\mu-\mathrm{O}) \mathrm{F}_{2} \mathrm{AlC}\left(\mathrm{SiMe}_{3}\right)_{3}\right]$ species contains two negative charges and is probably suited to generate weak coordinating anions as found in $\mathbf{3}$.

\subsection{Synthesis of $\left[\left\{\mathrm{Li}\left(\mathrm{Me}_{3} \mathrm{Si}_{3}\right)_{3} \mathrm{CAlF}_{3}(\mathrm{THF})\right\}_{3} \mathrm{LiF}(\mathrm{THF})\right](11)$}

After the successful introduction of fluoride at $\left(\mathrm{Me}_{3} \mathrm{Si}_{3}\right)_{3} \mathrm{CAlF}_{2} \cdot \mathrm{THF}$ in the synthesis of 9 it was intriguing to learn if alcoholates, which are isolobal [67] to fluoride, are useful as precursors for aluminum fluoro oxygen cluster compounds. $\mathrm{LiOCH}\left(\mathrm{CF}_{3}\right)_{2}$ was chosen to study the behavior of the $\left(\mathrm{Me}_{3} \mathrm{Si}\right)_{3} \mathrm{CAlF}_{2}$. THF molecule with deprotonated alcoholes.

MeLi was reacted with $\left(\mathrm{CF}_{3}\right)_{2} \mathrm{CH}(\mathrm{OH})$ in THF to generate $\mathrm{LiOCH}\left(\mathrm{CF}_{3}\right)_{2}$. This mixture was added to a solution of $\left(\mathrm{Me}_{3} \mathrm{Si}_{3} \mathrm{CAlF}_{2}\right.$.THF in THF. However, the reaction of $\left(\mathrm{Me}_{3} \mathrm{Si}\right)_{3} \mathrm{CAlF}_{2} \cdot \mathrm{THF}$ with $\mathrm{LiOCH}\left(\mathrm{CF}_{3}\right)_{2}$ afforded the unexpected compound $\left[\left\{\mathrm{Li}\left(\mathrm{Me}_{3} \mathrm{Si}_{3}\right)_{3} \mathrm{CAlF}_{3}(\mathrm{THF})\right\}_{3} \mathrm{LiF}(\mathrm{THF})\right](\mathbf{1 1})$ in low yield (Figure 5, Table 5, Scheme 7). It is assumed that the four LiF molecules necessary for the formation of $\mathbf{1 1}$ are formed by an exchange reaction of $\left(\mathrm{CF}_{3}\right)_{2} \mathrm{HCOLi}$ with $\left(\mathrm{Me}_{3} \mathrm{Si}\right)_{3} \mathrm{CAlF}_{2} \cdot \mathrm{THF}$ where the $\left(\mathrm{CF}_{3}\right)_{2} \mathrm{HCO}^{-}$is replacing a $\mathrm{F}^{-}$. Up to now it was not possible to isolate a compound with composition like $\left[\left(\mathrm{Me}_{3} \mathrm{Si}\right)_{3} \mathrm{CAlF}\left(\mathrm{OCH}\left(\mathrm{CF}_{3}\right)_{2}\right)\right] \cdot \mathrm{THF}$ to prove this assumption (Scheme 8). 


\section{$\left[\left\{\mathrm{Li}\left(\mathrm{Me}_{3} \mathrm{Si}_{3} \mathrm{CAlF}_{3}(\mathrm{THF})\right\}_{3} \mathrm{LiF}(\mathrm{THF})\right](\mathbf{1 1})\right.$ \\ $7\left(\mathrm{Me}_{3} \mathrm{Si}\right)_{3} \mathrm{CAlF}_{2} \cdot \mathrm{THF}+4 \mathrm{LiOCH}\left(\mathrm{CF}_{3}\right)_{2} \longrightarrow+4\left[\left(\mathrm{Me}_{3} \mathrm{Si}\right)_{3} \mathrm{CAlF}\left\{\mathrm{OCH}\left(\mathrm{CF}_{3}\right)_{2}\right\}\right] \cdot \mathrm{THF}$}

\section{Scheme 7}

The elemental analysis of $\mathbf{1 1}+$ THF for the elements $\mathrm{C}$ and $\mathrm{H}$ confirms the required composition of $\mathrm{C}_{50} \mathrm{H}_{121} \mathrm{Al}_{3} \mathrm{~F}_{10} \mathrm{Li}_{4} \mathrm{O}_{5} \mathrm{Si}_{9}$.

The ${ }^{1} \mathrm{H}$ NMR spectrum of $\mathbf{1 1}$ was recorded in THF- $\mathrm{d}_{8}$ due to its poor solubility in benzene. Decomposition in this strong coordinating solvent is presumed [45]. The proton spectrum of 11 shows a singlet for the protons of the trimethylsilyl ligand at $\delta 0.15 \mathrm{ppm}$. The resonances for the THF protons appear as multiplets at $\delta 1.77 \mathrm{ppm}\left(\mathrm{CH}_{2} \mathrm{CH}_{2} \mathrm{O}\right)$ and $3.61 \mathrm{ppm}$ $\left(\mathrm{CH}_{2} \mathrm{CH}_{2} \mathrm{O}\right)$.

The resonances of the fluorine atoms of $\mathbf{1 1}$ give a main singlet in the ${ }^{19} \mathrm{~F}$ NMR spectrum at $\delta$ $-166.5 \mathrm{ppm}$, and a very small singlet at $-202.8 \mathrm{ppm}$.

Compound 11 shows good stability in the gas phase which is demonstrated by a FAB experiment that gives an anion of $\mathbf{1 1}$ minus a lithium and a THF molecule.

$$
\left(\mathrm{Me}_{3} \mathrm{Si}\right)_{3} \mathrm{CAlF}_{2} \cdot \mathrm{THF}+\mathrm{LiOCH}\left(\mathrm{CF}_{3}\right)_{2} \stackrel{\mathrm{THF}}{\longrightarrow}\left[\left(\mathrm{Me}_{3} \mathrm{Si}\right)_{3} \mathrm{CAlF}\left\{\mathrm{OCH}\left(\mathrm{CF}_{3}\right)_{2}\right\}\right] \cdot \mathrm{THF}+\mathrm{LiF} \text { ? }
$$

Scheme 8. Assumption for the formation of the $\mathrm{LiF}$ that is implemented in the cluster of $\mathbf{1 1}$. 


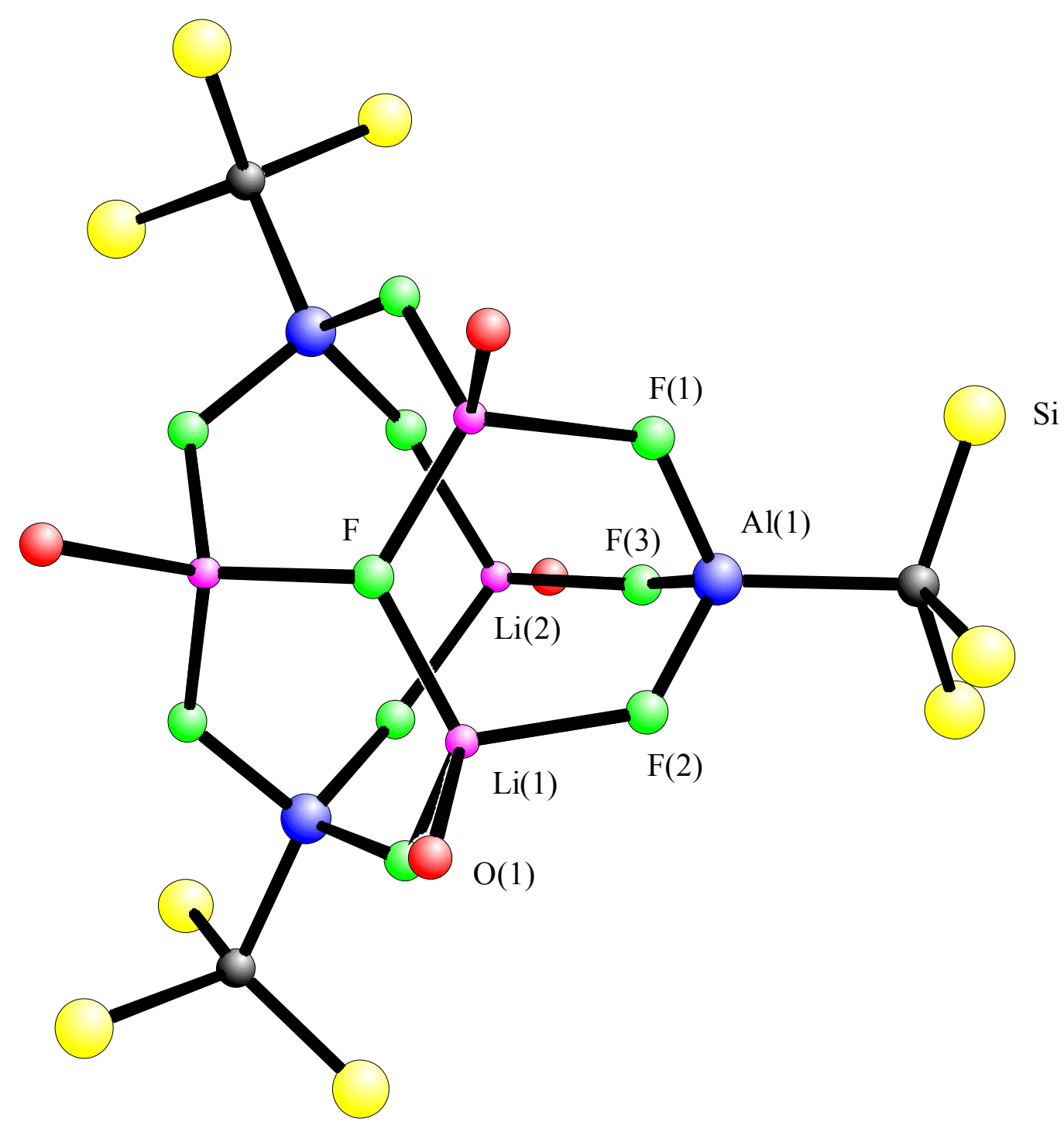

Figure 5. Molecular structure of $\left[\left\{\mathrm{Li}\left(\mathrm{Me}_{3} \mathrm{Si}\right)_{3} \mathrm{CAlF}_{3}(\mathrm{THF})\right\}_{3} \mathrm{LiF}(\mathrm{THF})\right](\mathbf{1 1})$. Me groups are omitted for clarity. Only the ipso oxygen atoms of THF are displayed.

The X-ray structural analysis reveals that $\mathbf{1 1}$ consists of three $\left[\left(\mathrm{Me}_{3} \mathrm{Si}\right)_{3} \mathrm{CAlF}_{3}\right]^{-}$anions interconnected with three Li-cations to form a twelve-membered ring. In the center on one side of this ring is a fluorine atom that is coordinated to three lithiums of the twelve-membered ring. The opposite side of the ring is occupied by a lithium atom that is coordinated to three fluorine atoms each of which is coordinated to an aluminum atom of the ring. The fourth coordination site of each of the Li atoms is occupied by an oxygen atom of a THF molecule. There is a threefold axis (Figure 5) going through $\operatorname{Li}(2)$ and $\mathrm{F}$ giving a 
molecule of high symmetry. The consequence of this symmetrical arrangement is that the three $\mathrm{Li}$ atoms of the twelve-membered ring form a perfect triangle of $\mathrm{Li}_{3}\left(\mathrm{Li}-\mathrm{Li}-\mathrm{Li} 60^{\circ}\right)$. The Al-F bond distances are in a narrow range (1.694(2) - 1.701(2) $\AA$ ). They are comparable to those in $\left[\mathrm{Li}\left(\mathrm{Me}_{3} \mathrm{Si}_{3} \mathrm{CAlF}_{3}(\mathrm{THF})\right]_{4}(\right.$ av $1.688 \AA$ ) [45] but are considerably shorter than the Al$\mathrm{F}$ (bridging) distances in $\left[\left(\mathrm{Me}_{3} \mathrm{Si}_{3} \mathrm{CAlF}_{2}\right]_{3}(1.795\right.$ - $1.815 \AA$ ) [43]. The Li-F bond lengths are in the range of $1.801(6)-1.873(6) \AA$ and close to the Li-F distances in $\mathbf{1 0}(1.835(5)$ to 1.854(4) $\AA$ ). The C-Al-F angles cover a range of $113.36(11)-115.74(13)^{\circ}$ and are wider than those in $\mathbf{1 0}\left(109.17(9)-111.06(10)^{\circ}\right)$. The Al-F-Li angles range from 125.3(2) to 149.6(3) ${ }^{\circ}$ (10 120.60(15) - 128.51(17) $)^{\circ}$.

Table 5. Selected bond lengths $(\AA)$ and angles (deg) for $\mathbf{1 1 .}$

\begin{tabular}{|c|c|c|c|}
\hline $\mathrm{F}(1)-\mathrm{Al}(1)$ & $1.694(2)$ & $F(2)-\operatorname{Li}(1)$ & $1.856(7)$ \\
\hline $\mathrm{F}(2)-\mathrm{Al}(1)$ & $1.697(2)$ & $\mathrm{F}(3)-\operatorname{Li}(2)$ & $1.864(3)$ \\
\hline $\mathrm{F}(3)-\mathrm{Al}(1)$ & $1.701(2)$ & C-Al(1) & 1.971(3) \\
\hline $\mathrm{F}-\mathrm{Li}(1)$ & $1.801(6)$ & $\operatorname{Li}(1)-\mathrm{O}(1)$ & $1.932(6)$ \\
\hline $\mathrm{F}(1)-\operatorname{Li}(1) \# 1$ & $1.873(6)$ & $\mathrm{Li}(2)-\mathrm{O}(2)$ & $1.950(8)$ \\
\hline $\operatorname{Li}(1) \# 2-\operatorname{Li}(1)-\operatorname{Li}(1) \# 1$ & 60.000 & $\operatorname{Li}(1) \# 1-F-\operatorname{Li}(1)$ & $119.64(5)$ \\
\hline $\operatorname{Al}(1)-\mathrm{F}(1)-\operatorname{Li}(1) \# 1$ & $125.3(2)$ & $\mathrm{F}-\mathrm{Li}(1)-\mathrm{F}(2)$ & 108.3(3) \\
\hline $\mathrm{Al}(1)-\mathrm{F}(2)-\mathrm{Li}(1)$ & $128.9(2)$ & $\mathrm{F}-\mathrm{Li}(1)-\mathrm{F}(1) \# 2$ & 112.1(3) \\
\hline $\mathrm{Al}(1)-\mathrm{F}(3)-\mathrm{Li}(2)$ & 149.6(3) & $F(2)-\operatorname{Li}(1)-F(1) \# 2$ & $104.8(3)$ \\
\hline $\mathrm{F}(1)-\mathrm{Al}(1)-\mathrm{F}(2)$ & $103.28(12)$ & $F(3)-\operatorname{Li}(2)-F(3) \# 1$ & $110.8(2)$ \\
\hline $\mathrm{F}(1)-\mathrm{Al}(1)-\mathrm{F}(3)$ & $104.47(13)$ & $\mathrm{F}-\mathrm{Li}(1)-\mathrm{O}(1)$ & $117.2(3)$ \\
\hline $\mathrm{F}(2)-\mathrm{Al}(1)-\mathrm{F}(3)$ & $105.08(12)$ & $\mathrm{F}(2)-\mathrm{Li}(1)-\mathrm{O}(1)$ & $112.2(3)$ \\
\hline $\mathrm{F}(1)-\mathrm{Al}(1)-\mathrm{C}$ & $113.36(11)$ & $\mathrm{F}(1) \# 2-\mathrm{Li}(1)-\mathrm{O}(1)$ & $101.5(3)$ \\
\hline $\mathrm{F}(2)-\mathrm{Al}(1)-\mathrm{C}$ & $113.66(12)$ & $\mathrm{F}(3)-\mathrm{Li}(2)-\mathrm{O}(2)$ & 108.1(2) \\
\hline $\mathrm{F}(3)-\mathrm{Al}(1)-\mathrm{C}$ & $115.74(13)$ & & \\
\hline
\end{tabular}


The easy generation of $\mathbf{1 1}$ is due to its insolubility in toluene. Complex $\mathbf{1 1}$ illustrates the variety of possible structures obtainable by the combination of $\left[\left(\mathrm{Me}_{3} \mathrm{Si}\right)_{3} \mathrm{CAlF}_{2}\right]_{3}$ and $\mathrm{LiF}$. In the series of the alkali metals the lithium derivative $\mathbf{1 1}$ has a different structural arrangement compared to those of the analogous compounds of the heavier alkali metals.

\subsection{Synthesis of $\left[\left\{\left(\mathrm{Me}_{3} \mathrm{Si}\right)_{3} \mathrm{C}\right\}_{2} \mathrm{Al}_{2}(\mu-\mathrm{F}) \mathrm{F}_{4} \mathrm{~K}\right]_{\infty}(12)$}

It is known that organoaluminum difluorides form various aggregates in the presence of THF due to the Lewis base character of this solvent and the Lewis acidity site of the aluminum. Consequently different structural arrangements were isolated when these systems were treated with THF [46]. Compound 2 for example contains four molecules of coordinated THF. Therefore it was interesting to investigate the THF free analogous compound. Additionally new interesting compositions could be produced by studying the bearing of $\mathbf{1}$ in the presence of reductive metals. The reduction of $\left(\mathrm{Me}_{3} \mathrm{Si}\right)_{3} \mathrm{CAlI}_{2} \cdot \mathrm{THF}$ with sodium potassium alloy affords the tetrahedral aluminum(I) compound $\left[\left(\mathrm{Me}_{3} \mathrm{Si}\right)_{3} \mathrm{CAl}\right]_{4}[59]$. It is reported that $\mathbf{1}$ resists reduction to aluminum(I) with alkali alloys [68].

Compound 12 was prepared from 1 with water free potassium fluoride in toluene under reflux in moderate yield. Using potassium metal and $\mathbf{1}$ under reflux conditions in toluene surprisingly produced compound 12, too (Scheme 9). The by-product of this reaction could not be characterized. The yield of $\mathbf{1 2}$ using the latter method is slightly higher than the first one.

$$
\begin{aligned}
& 2\left[\left(\mathrm{Me}_{3} \mathrm{Si}\right)_{3} \mathrm{CAlF}_{2}\right]_{3}+3 \mathrm{KF} \quad \frac{\text { toluene }}{\text { reflux }} \\
& 3\left[\left(\mathrm{Me}_{3} \mathrm{Si}_{3} \mathrm{CAlF}_{2}\right]_{3}+3 \mathrm{~K}_{(\text {metal })} \frac{\text { toluene }}{\text { reflux }} \mathbf{1 2}\right. \\
& -{ }^{\prime}\left[\left\{\left(\mathrm{Me}_{3} \mathrm{Si}\right)_{3} \mathrm{C}\right\}_{3} \mathrm{Al}_{3} \mathrm{~F}_{3}\right]^{\prime}
\end{aligned}
$$

\section{Scheme 9}


Compound $\mathbf{1 2}$ is slightly soluble in toluene at room temperature. However the solubility increases when heated under reflux. 12 dissolves easily in THF but dissociates in this strong coordinating solvent [49].

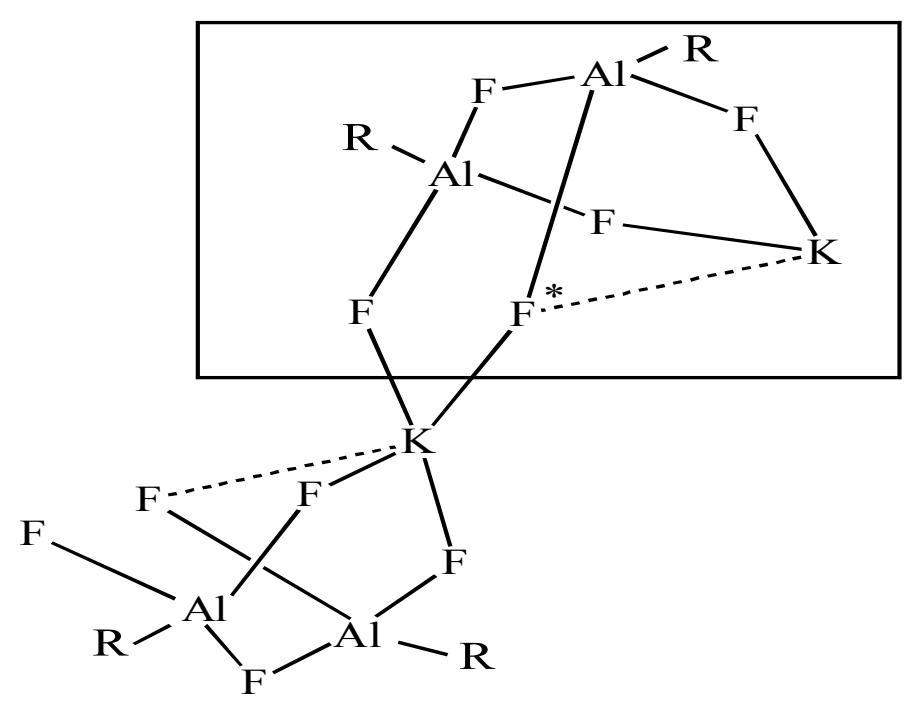

Scheme 10. Drawing of 12. The rectangle shows the single unit of the supramolecular chain. The asterisk marked fluorine atom shows the $\mathrm{F}(4)$ atom from the X-ray structural analysis which occupies the weak fifth coordination site of the potassium atom. $\mathrm{R}=\mathrm{C}\left(\mathrm{SiMe}_{3}\right)_{3}$.

The elemental analysis for $\mathrm{C}$ and $\mathrm{H}$ confirms the required composition of $\mathrm{C}_{20} \mathrm{H}_{54} \mathrm{Al}_{2} \mathrm{~F}_{5} \mathrm{KSi}_{6}$.

The proton resonance in the ${ }^{1} \mathrm{H}$ NMR spectrum is observed at $\delta 0.42 \mathrm{ppm}$.

The ${ }^{19} \mathrm{~F}$ NMR spectrum of $\mathbf{1 2}$ shows resonances for the fluorine atoms at $\delta$ - $157.5 \mathrm{ppm}(\mathrm{s}, 4 \mathrm{~F}$, $\mathrm{Al}(\mu-\mathrm{F}) \mathrm{K}),-157.3 \mathrm{ppm}(\mathrm{s}, 4 \mathrm{~F}, \mathrm{Al}(\mu-\mathrm{F}) \mathrm{K}),-156.9 \mathrm{ppm}(\mathrm{s}, 1 \mathrm{~F})$, and -152.8 ppm (m, $2 \mathrm{~F}$, $\mathrm{Al}(\mu-\mathrm{F}) \mathrm{Al})$. It is assumed that the multiplet at $\delta-152.8 \mathrm{ppm}$ is an unresolved quintet $(\mathrm{J}=30$ $\mathrm{Hz})$ and the resonances at $\delta-157.5 \mathrm{ppm}$ and $\delta-157.3 \mathrm{ppm}$ are the associated doublets $(\mathrm{J}=30$ $\mathrm{Hz})$ with the intensity ratio of $1: 4$ as is expected for the $\left[\left(\mathrm{Me}_{3} \mathrm{Si}_{3} \mathrm{CAlF}_{2}(\mu-\right.\right.$ $\left.\mathrm{F}) \mathrm{F}_{2} \mathrm{AlC}\left(\mathrm{SiMe}_{3}\right)_{3}\right]^{-}$anion in 12. This coupling is hard to recognize in the ${ }^{19} \mathrm{~F}$ NMR spectrum. The source for the resonance at $\delta-156.9 \mathrm{ppm}$ is unknown. For compound $\mathbf{3}$ the resonances in the ${ }^{19} \mathrm{~F}$ NMR are reported in the same range $(\delta-158.8(\mathrm{~s}, 4 \mathrm{~F}),-158.6(\mathrm{~s}, 4 \mathrm{~F}),-158.0(\mathrm{~s}, 1 \mathrm{~F})$, and $154.5(\mathrm{~m}, 2 \mathrm{~F}) \mathrm{ppm})$ while the resonance at $\delta-156.9 \mathrm{ppm}$ is obviously produced by the same impurity. 


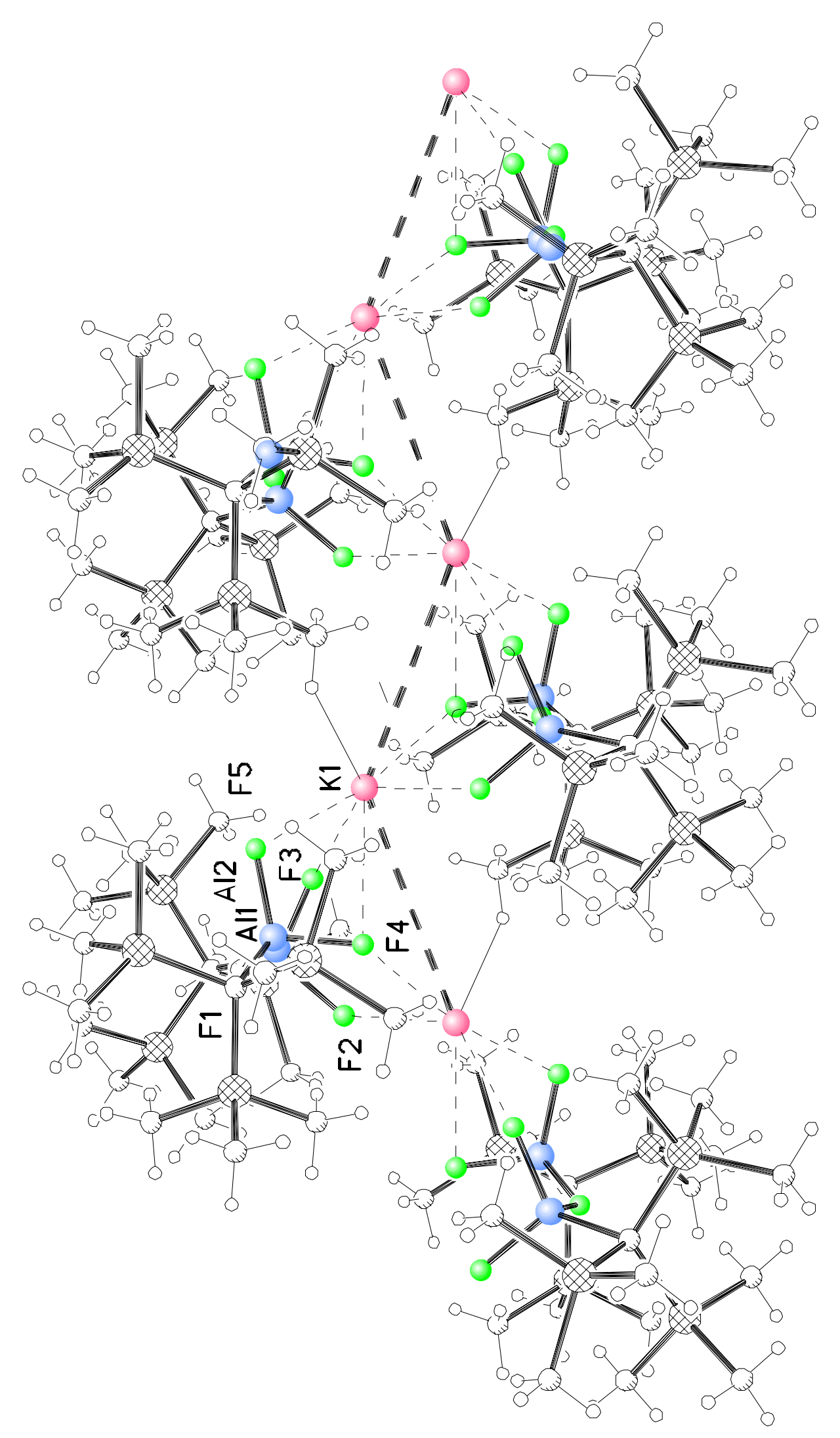

Figure 6. Arrangement of $\mathbf{1 2}$ in the chain. The potassium atoms are in the paperplane. (blue atoms $=$ aluminum, pink atoms $=$ potassium, green atoms $=$ fluorine $)$ 
Suitable single crystals for X-ray structural analysis of 12 (Figure 6, Table 6), were obtained from hot toluene. The structure of $\mathbf{1 2}$ consists of infinite potassium zig-zag chains with a K-K distance of 4.7800(7) $\AA$ which is slightly longer than that in potassium metal (av $4.54 \AA$ ) [41] (Figure 6). The potassium atoms are fourfold coordinated by terminal fluorine atoms of the $\left[\left(\mathrm{Me}_{3} \mathrm{Si}_{3}\right)_{3} \mathrm{CAlF}_{2}(\mu-\mathrm{F}) \mathrm{F}_{2} \mathrm{AlC}\left(\mathrm{SiMe}_{3}\right)_{3}\right]^{-}$anions (Figure 7). The K-F bond length ranges from $2.5990(17)$ to $2.6587(18) \AA$ which is slightly shorter or comparable to that in KF (2.664 $\AA)$ [41] but in the range of those in $2(2.610-2.860 \AA)$. Within the four terminal fluorine atoms of $12 \mathrm{~F}(4)$ is weakly coordinating to a second potassium atom with a distance of 3.147(2) $\AA$ which is slightly $(0.5 \AA)$ longer than the other observed K-F distances in this molecule (Scheme 10). The Al-F(terminal) bond length (1.6820(18) - 1.6940(19) Å) is slightly longer than those in $3(1.657-1.688 \AA)$ and in $2(1.672-1.677 \AA)$ respectively. The Al-F(bridging) bond length (1.8028(17) - 1.8144(17) $\AA$ ) is comparable to that in $3(1.7881-1.802 \AA)$ and in $2\left(1.817\right.$ - $1.823 \AA$ ). The F-K-F angles are acute for $\mathrm{F}(2) \# 1-\mathrm{K}(1)-\mathrm{F}(4) \# 1\left(73.30(5)^{\circ}\right)$ and $\mathrm{F}(3)$ $\mathrm{K}(1)-\mathrm{F}(5)\left(72.57(5)^{\circ}\right)$ and more open for $\mathrm{F}(3)-\mathrm{K}(1)-\mathrm{F}(4) \# 1\left(114.14(6)^{\circ}\right)$ and $\mathrm{F}(2) \# 1-\mathrm{K}(1)-\mathrm{F}(5)$ $\left(109.56(6)^{\circ}\right)$. All potassium atoms in the chain are in plane with a K-K-K angle of $137.74(3)^{\circ}$ (Figure 6). The potassium in $\mathbf{2}$ is sixfold-coordinated by four fluorines and two oxygens of the THF molecules. In contrast, the potassium in $\mathbf{1 2}$ has the coordination number four with a fifth fluorine atom in a weak contact.

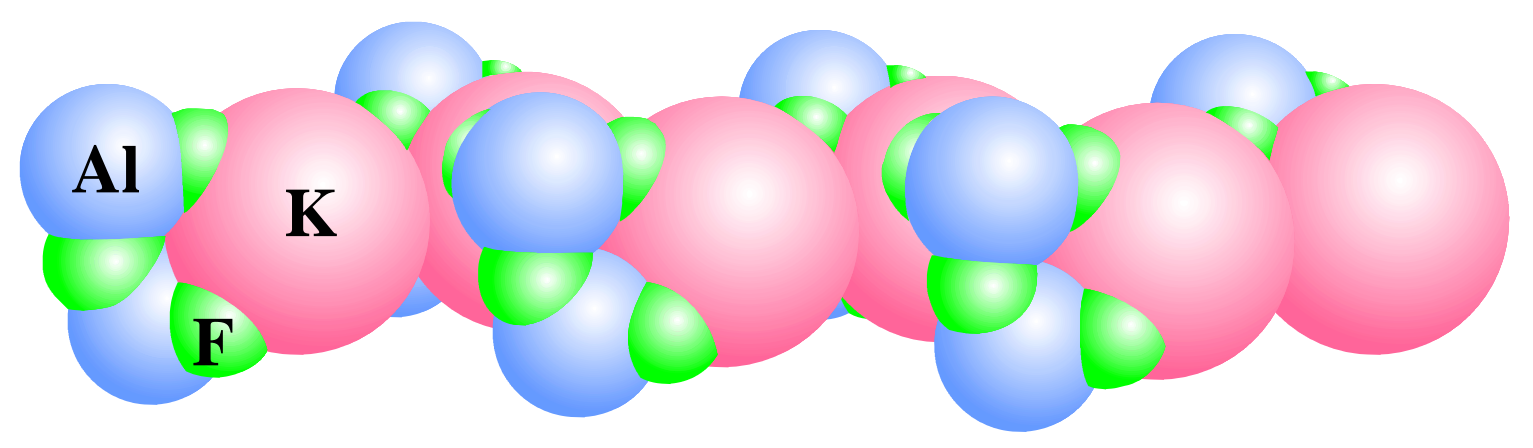

Figure 7. Van der Waals plot of a section of the infinite chain of 12. The $\mathrm{C}\left(\mathrm{SiMe}_{3}\right)_{3}$ ligand is omitted for clarity. (blue atoms $=$ aluminum, pink atoms $=$ potassium, green atoms $=$ fluorine $)$ 
These investigations indicate the activation of the Al-F bonds using KF in the absence of a coordinating solvent. This example is an interesting model for the activation of $\mathrm{AlF}_{3}$ in the presence of KF. Fluorides of aluminum find use as catalysts for the sythesis of new chlorofluorocarbon alternatives [8].

Table 6. Selected bond lengths $[\AA]$ and angles $\left[{ }^{\circ}\right]$ for $\mathbf{1 2 .}$

\begin{tabular}{|c|c|c|c|}
\hline $\mathrm{K}(1)-\mathrm{F}(2) \# 1$ & $2.6347(17)$ & $\mathrm{Al}(1)-\mathrm{F}(1)$ & $1.8144(17)$ \\
\hline $\mathrm{K}(1)-\mathrm{F}(3)$ & $2.5990(17)$ & $\mathrm{Al}(1)-\mathrm{F}(2)$ & $1.6940(19)$ \\
\hline $\mathrm{K}(1)-\mathrm{F}(4) \# 1$ & $2.6441(18)$ & $\mathrm{Al}(1)-\mathrm{F}(3)$ & $1.6820(18)$ \\
\hline $\mathrm{K}(1)-\mathrm{F}(4)$ & $3.147(2)$ & $\mathrm{Al}(2)-\mathrm{F}(1)$ & $1.8028(17)$ \\
\hline $\mathrm{K}(1)-\mathrm{F}(5)$ & $2.6587(18)$ & $\mathrm{Al}(2)-\mathrm{F}(4)$ & $1.6922(17)$ \\
\hline $\mathrm{K}(1)-\mathrm{Al}(2)$ & $3.5933(11)$ & $\mathrm{Al}(2)-\mathrm{F}(5)$ & $1.6865(19)$ \\
\hline $\mathrm{Al}(1)-\mathrm{C}(1)$ & $1.953(3)$ & $\mathrm{Al}(2)-\mathrm{C}(2)$ & $1.948(3)$ \\
\hline $\mathrm{F}(3)-\mathrm{K}(1)-\mathrm{F}(2) \# 1$ & $132.31(7)$ & $\mathrm{F}(4)-\mathrm{Al}(2)-\mathrm{F}(1)$ & $97.56(8)$ \\
\hline $\mathrm{F}(3)-\mathrm{K}(1)-\mathrm{F}(4) \# 1$ & $114.14(6)$ & $\mathrm{Al}(2)-\mathrm{F}(1)-\mathrm{Al}(1)$ & $129.47(9)$ \\
\hline $\mathrm{F}(2) \# 1-\mathrm{K}(1)-\mathrm{F}(4) \# 1$ & $73.30(5)$ & $\mathrm{Al}(1)-\mathrm{F}(2)-\mathrm{K}(1) \# 2$ & $131.60(10)$ \\
\hline $\mathrm{F}(3)-\mathrm{K}(1)-\mathrm{F}(5)$ & $72.57(5)$ & $\mathrm{Al}(1)-\mathrm{F}(3)-\mathrm{K}(1)$ & $145.68(9)$ \\
\hline $\mathrm{F}(2) \# 1-\mathrm{K}(1)-\mathrm{F}(5)$ & $109.56(6)$ & $\mathrm{Al}(2)-\mathrm{F}(4)-\mathrm{K}(1) \# 2$ & $143.54(10)$ \\
\hline$F(4) \# 1-K(1)-F(5)$ & $168.62(6)$ & $\mathrm{Al}(2)-\mathrm{F}(4)-\mathrm{K}(1)$ & $90.79(8)$ \\
\hline $\mathrm{F}(3)-\mathrm{K}(1)-\mathrm{F}(4)$ & $65.27(5)$ & $\mathrm{Al}(2)-\mathrm{F}(5)-\mathrm{K}(1)$ & $109.54(8)$ \\
\hline $\mathrm{F}(2) \# 1-\mathrm{K}(1)-\mathrm{F}(4)$ & $78.02(5)$ & $\mathrm{K}(1) \# 2-\mathrm{F}(4)-\mathrm{K}(1)$ & $110.97(5)$ \\
\hline $\mathrm{F}(4) \# 1-\mathrm{K}(1)-\mathrm{F}(4)$ & $136.73(5)$ & $\mathrm{K}(1) \# 2-\mathrm{K}(1)-\mathrm{K}(1) \# 1$ & $137.74(3)$ \\
\hline $\mathrm{F}(5)-\mathrm{K}(1)-\mathrm{F}(4)$ & $53.89(5)$ & $\mathrm{F}(3)-\mathrm{Al}(1)-\mathrm{C}(1)$ & $116.87(11)$ \\
\hline $\mathrm{F}(3)-\mathrm{Al}(1)-\mathrm{F}(2)$ & $106.66(10)$ & $\mathrm{F}(2)-\mathrm{Al}(1)-\mathrm{C}(1)$ & $118.33(11)$ \\
\hline $\mathrm{F}(3)-\mathrm{Al}(1)-\mathrm{F}(1)$ & $98.73(9)$ & $\mathrm{F}(1)-\mathrm{Al}(1)-\mathrm{C}(1)$ & $114.16(10)$ \\
\hline $\mathrm{F}(2)-\mathrm{Al}(1)-\mathrm{F}(1)$ & $99.01(9)$ & $\mathrm{F}(5)-\mathrm{Al}(2)-\mathrm{C}(2)$ & $118.42(11)$ \\
\hline
\end{tabular}




$\begin{array}{llll}\mathrm{F}(5)-\mathrm{Al}(2)-\mathrm{F}(4) & 104.21(9) & \mathrm{F}(4)-\mathrm{Al}(2)-\mathrm{C}(2) & 116.85(10) \\ \mathrm{F}(5)-\mathrm{Al}(2)-\mathrm{F}(1) & 100.46(9) & \mathrm{F}(1)-\mathrm{Al}(2)-\mathrm{C}(2) & 116.14(10)\end{array}$

\subsection{Synthesis of New Organoaluminum fluorides}

One of the primary objectives concerning fluorine based science in our research group has been the development of new fluorinating agents in recent years. $\mathrm{AsF}_{3}$ was used, for example, successfully with $\mathrm{Cp}^{\prime} \mathrm{TiCl}_{3}$ for the synthesis of $\mathrm{Cp}^{\prime} \mathrm{TiF}_{3}\left(\mathrm{Cp}^{\prime}=\mathrm{C}_{5} \mathrm{Me}_{4} \mathrm{Et}[70]\right)$ and for $\mathrm{Cp}^{*} \mathrm{MF}_{4}$ $(\mathrm{M}=\mathrm{Nb}$ [40], Ta [71]). However, the most reliable fluorinating agent for transition metals proved to be $\mathrm{Me}_{3} \mathrm{SnF}$. The metathesis of fluoride and chloride yields $\mathrm{Me}_{3} \mathrm{SnCl}$ which can be recycled easily by using $\mathrm{KF}$ or $\mathrm{NaF}$ to gain the fluorinating agent $\mathrm{Me}_{3} \mathrm{SnF}$ [34].

$\mathrm{Me}_{3} \mathrm{SnF}$ also finds use in the synthesis of organoaluminum difluorides [19, 43]. But the metathesis in these reactions of fluoride and a methyl produces $\mathrm{Me}_{4} \mathrm{Sn}$ which cannot be recycled easily unlike $\mathrm{Me}_{3} \mathrm{SnCl}$ (Scheme 11).

$$
\begin{array}{lll}
\mathrm{Cp}^{*} \mathrm{MCl}_{3}+3 \mathrm{Me}_{3} \mathrm{SnF} & \longrightarrow & \mathrm{Cp}^{*} \mathrm{MF}_{3}+3 \mathrm{Me}_{3} \mathrm{SnCl} \\
\mathrm{Me}_{3} \mathrm{SnCl}+\mathrm{KF} & & \mathrm{Me}_{3} \mathrm{SnF}+\mathrm{KCl} \\
& & \\
3\left(\mathrm{R}^{\prime} \mathrm{AlMe}\right)_{2}+12 \mathrm{Me}_{3} \mathrm{SnF} & \longrightarrow & 2\left(\mathrm{R}^{\prime} \mathrm{AlF}_{2}\right)_{3}+12 \mathrm{Me}_{4} \mathrm{Sn} \\
3 \mathrm{R}^{\prime} \mathrm{AlMe}_{2} \cdot \mathrm{THF}+6 \mathrm{Me}_{3} \mathrm{SnF} & \longrightarrow & \left(\mathrm{R}^{\prime} \mathrm{AlF}_{2}\right)_{3}+6 \mathrm{Me}_{4} \mathrm{Sn}+3 \mathrm{THF} \\
3 \mathrm{Me}_{4} \mathrm{Sn}+\mathrm{SnCl}_{4} & \longrightarrow & 4 \mathrm{Me}_{3} \mathrm{SnCl}
\end{array}
$$

Scheme 11. $M=T i, Z r$, Hf [34]; $\mathrm{R}^{\prime}=\mathrm{N}\left(\mathrm{SiMe}_{3}\right)\left(2,6-i \mathrm{Pr}_{2} \mathrm{C}_{6} \mathrm{H}_{3}\right)[19] ; \mathrm{R}^{\prime \prime}=\mathrm{C}\left(\mathrm{SiMe}_{3}\right)_{3}$ [43]. 
Alternatives to $\mathrm{Me}_{3} \mathrm{SnF}$ like $\mathrm{Ph}_{2} \mathrm{PbF}_{2}$ and $\mathrm{Ph}_{2} \mathrm{BiF}$ for the metathesis reactions of group 4 and 5 compounds has been described [72].

Alkali metal fluorides can be used for the synthesis of organofluoroaluminates. $\mathrm{Cs}\left[i \mathrm{Bu}_{3} \mathrm{AlF}\right]$ for example they can be obtained by the reaction of $\mathrm{Al}(i \mathrm{Bu})_{3}$ with $\mathrm{CsF}$ as a fluorination agent for organometallic compounds of the elements of group 13 in toluene [73].

Examples of organoaluminum difluorides are rare [18]. Roesky et al. synthesized the compounds 1 [43], $\left[\mathrm{RAlF}_{2}\right]_{3}\left\{\left(\mathrm{R}=\mathrm{N}\left(\mathrm{SiMe}_{3}\right)\left(2,6-i \mathrm{Pr}_{2} \mathrm{C}_{6} \mathrm{H}_{3}\right), \mathrm{N}\left(\mathrm{Si} t \mathrm{BuMe}_{2}\right)\left(2,6-\mathrm{Me}_{2} \mathrm{C}_{6} \mathrm{H}_{3}\right)\right\}\right.$ [19], and $\left[\left\{\mathrm{N}\left(\mathrm{SiMe}_{3}\right) \mathrm{C}(\mathrm{Ph}) \mathrm{C}\left(\mathrm{CiMe}_{3}\right)_{2}\right\} \mathrm{AlF}(\mu-\mathrm{F})\right]_{2}$ [74] and characterized them by X-ray single crystal structural analysis.

\subsubsection{Attempted Reaction of $\mathrm{Me}_{3} \mathrm{SnF}$ with DDPAIMe}

No reaction of $\mathrm{Me}_{3} \mathrm{SnF}$ [75] with DDPAlMe 2 in a molar ratio 2: 1 in THF has been observed [DDPH $=(2-\{(2,6$-diisopropylphenyl $)$ amino $\}-4-\{(2,6$-diisopropylphenyl $)$ imino $\}-2-$ pentene $]$.

\subsubsection{Synthesis of $\left(\mathrm{CycMe}_{2} \mathrm{Si}\right)\left(\mathrm{Me}_{3} \mathrm{Si}\right)_{2} \mathrm{CAlF}_{2} \cdot \mathrm{THF}(13)$}

$\left(\mathrm{Me}_{3} \mathrm{Si}\right)_{3} \mathrm{CAlF}_{2} \cdot \mathrm{THF}$ is available in a facile way by the reaction of $\left(\mathrm{Me}_{3} \mathrm{Si}\right)_{3} \mathrm{CAlMe}_{2} \cdot \mathrm{THF}$ with $\mathrm{Me}_{3} \mathrm{SnF}$. It seemed to be easy to react the compound $\left(\mathrm{CycMe}_{2} \mathrm{Si}\right)\left(\mathrm{Me}_{3} \mathrm{Si}\right)_{2} \mathrm{CAlMe} \cdot \mathrm{THF}$ [76] with $\mathrm{Me}_{3} \mathrm{SnF}$ in a similar route.

$\left(\mathrm{CycMe}_{2} \mathrm{Si}\right)\left(\mathrm{Me}_{3} \mathrm{Si}\right)_{2} \mathrm{CAlMe} \cdot \mathrm{THF}$ was treated with 2 equivalents $\mathrm{Me}_{3} \mathrm{SnF}$ in $\mathrm{THF}$ (Scheme 12). The volatiles were evaporated in vacuum. Crystallization of the residue from THF at $-20{ }^{\circ} \mathrm{C}$ afforded $13(71 \%)$ in moderate yield.

$\mathrm{RAlMe}_{2} \cdot \mathrm{THF}+2 \mathrm{Me}_{3} \mathrm{SnF} \longrightarrow \mathrm{R}^{\prime} \mathrm{AlF}_{2} \cdot \mathrm{THF}+2 \mathrm{Me}_{4} \mathrm{Sn}$

Scheme 12. $\mathrm{R}=\left(\mathrm{CycMe}_{2} \mathrm{Si}\right)\left(\mathrm{Me}_{3} \mathrm{Si}\right)_{2} \mathrm{C}$. 
The ${ }^{1} \mathrm{H}$ NMR resonances of $\mathbf{1 3}$ are found in the expected range differing only slightly from those of the heavier halide congeners $\left(\mathrm{CycMe} \mathrm{Si}_{2}\right)\left(\mathrm{Me}_{3} \mathrm{Si}\right)_{2} \mathrm{CAlX}_{2} \cdot \mathrm{THF}(\mathrm{X}=\mathrm{Cl}, \mathrm{Br}, \mathrm{I})[76]$.

The ${ }^{19} \mathrm{~F}$ NMR shows a sharp resonance for the fluorine atoms (at $\delta$-156.5 ppm).

In the EI-MS of 13 the fragment $\left(\mathrm{Me}_{3} \mathrm{Si}\right)_{2} \mathrm{CHSiMe}_{2}$ is observed (at $\mathrm{m} / z$ 217) with $100 \%$ intensity.

Attempts to grow suitable crystals (in toluene) for an X-ray diffraction analysis were unsuccessful. It was not possible to remove the THF of $\mathbf{1 3}$ in vacuo at high temperatures in a similar way as it is described for $\mathbf{1}$ (Scheme 1) due to the fact that $\mathbf{1 3}$ melts $\left(108^{\circ} \mathrm{C}\right.$ ) and decomposes. Further investigations on $\mathbf{1 3}$ seemed to be less interesting.

\subsubsection{Attempted Synthesis of $\left(2,6-t \mathrm{Bu}_{2} \mathrm{C}_{6} \mathrm{H}_{3} \mathrm{O}\right) \mathrm{AlF}_{2} \cdot \mathrm{THF}$}

$\mathrm{Me}_{3} \mathrm{Al}$ reacts with sterically hindered 2,6-di-tert-butyl-substituted phenols [77]. In the reaction of 2,6-di-tert-butyl-4-methylphenol (DBMP-H) with $\mathrm{Me}_{3} \mathrm{Al}$, the species observed are $\mathrm{Me}_{3} \mathrm{Al}, \mathrm{Al}_{2} \mathrm{Me}_{5} \mathrm{DBMP}, \mathrm{AlMe}_{2} \mathrm{DBMP}$, and $\mathrm{AlMeDBMP}$. It has been reported, that species of type DBPAlMeX-(NH $\left.\mathrm{NH}_{2} t \mathrm{Bu}\right)\left(\mathrm{DBP}-\mathrm{H}=\left(2,6-t \mathrm{Bu}_{2} \mathrm{C}_{6} \mathrm{H}_{3}\right) \mathrm{OH} ; \mathrm{X}=\mathrm{Me}, \mathrm{Cl}, \mathrm{Br}\right)$ [78] or (DBMP)AlMe $\mathrm{Al}_{2}$ (pyridine) [79] are characterizable by X-ray structure analysis. The synthesis of a similar difluoride analogue with coordinated THF was attempted. Up to now it was not possible to isolate the desired $\mathrm{DBPAlF}_{2} \cdot \mathrm{THF}$ product by reaction of $\mathrm{DBPAlMe} \mathrm{A}_{2} \cdot \mathrm{THF}$ with $\mathrm{Me}_{3} \mathrm{SnF}$ in THF in a ratio of $1: 2$. Several resonances in the ${ }^{19} \mathrm{~F}$ NMR spectrum in the range $\delta-140 \mathrm{ppm}$ to $-170 \mathrm{ppm}$ indicated a mixture of products. 


\subsubsection{Synthesis of $\left(2,6-t \mathrm{Bu}_{2} \mathrm{C}_{6} \mathrm{H}_{3} \mathrm{O}\right)_{2} \mathrm{AlF} \cdot \mathrm{THF}(14)$}

The compound $(\mathrm{DBP})_{2} \mathrm{AlMe}$ is reported $[76,80]$. The synthesis of a similar difluoride analogue with coordinated THF was attempted.

$\mathrm{DBP}_{2} \mathrm{AlMe}\left[77\right.$ ] and $\mathrm{Me}_{3} \mathrm{SnF}$ (1 eq) were stirred in THF for $24 \mathrm{~h}$. All volatiles were removed in vacuo. Crystallization from $\mathrm{THF}$ at $-20{ }^{\circ} \mathrm{C}$ resulted in products of the composition $\mathrm{DBP}_{2} \mathrm{AlF} \cdot \mathrm{THF}(82 \%)$. The colorless solid melts at $135-136^{\circ} \mathrm{C}$.

$\left(2,6-t \mathrm{Bu}_{2} \mathrm{C}_{6} \mathrm{H}_{3} \mathrm{O}\right)_{2} \mathrm{AlMe} \cdot \mathrm{THF}+\mathrm{Me}_{3} \mathrm{SnF}$

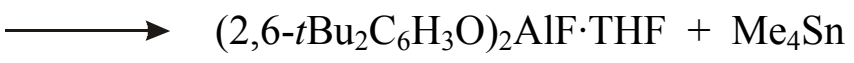

14

\section{Scheme 13}

The elemental analysis for $\mathrm{C}$ and $\mathrm{H}$ confirms the composition $\mathrm{C}_{32} \mathrm{H}_{50} \mathrm{AlFO}_{3}$.

The ${ }^{1} \mathrm{H}$ NMR of $\mathbf{1 4}$ reveals resonances for the protons as expected for one $\left(2,6-t \mathrm{Bu}_{2} \mathrm{C}_{6} \mathrm{H}_{3} \mathrm{O}\right)$ ligand together with resonances of one coordinated THF with correct relation of the integrals. The fluorine atoms show resonances (at $\delta-161.8 \mathrm{ppm}$ ) in the ${ }^{19} \mathrm{~F}$ NMR as sharp singlet. In the EI-MS spectrum, the molecule peak [at $\mathrm{m} / \mathrm{z}, 528$ ] and the THF free molecule fragment [at $\mathrm{m} / \mathrm{z} 456$ ] are observed with the intensity of 20 and $60 \%$, respectively.

It was so far unsuccessful to obtain suitable single crystals for an X-ray structure analysis. 


\subsection{Synthesis of $\left[n \mathrm{Bu}_{4} \mathrm{~N}\right]\left[\left(\mathrm{Me}_{3} \mathrm{Si}\right)_{3} \mathrm{CAIMeF}_{2}\right](15)$}

Group 13 difluorodiorganometalates have been known since 1955 [13,81]; however, only a few of these were spectroscopically and structurally characterized [73,82-85]. Furthermore, the synthesis of these anions was not straightforward.

The X-ray crystal structures and spectroscopic characterization of some difluorodiorganometalates, $\left[n \mathrm{Bu}_{4} \mathrm{~N}\right]\left[\mathrm{Me}_{2} \mathrm{MF}_{2}\right](\mathrm{M}=\mathrm{Al}, \mathrm{Ga}, \mathrm{In})$ have been described [86]. The synthesis of these compounds is accomplished through protonolysis of trialkyl derivatives of the group 13 metals with tetra-nbutylammonium hydrogen difluoride (TBADF) [87], which induces elimination of methane and addition of two fluoride ions. In the series of group 13 difluorodiorganometalates it was intriguing to synthesize an aluminum analogue with a bulky ligand like $\left(\mathrm{Me}_{3} \mathrm{Si}\right)_{3} \mathrm{C}$ instead of a small methyl group.

Treatment of $\left(\mathrm{Me}_{3} \mathrm{Si}_{3}\right)_{3} \mathrm{CAlMe} \mathrm{M}_{2}$ THF with an equimolar amount of TBADF in THF at room temperature afforded $\left[n \mathrm{Bu}_{4} \mathrm{~N}\right]\left[\left(\mathrm{Me}_{3} \mathrm{Si}\right)_{3} \mathrm{CAlMeF}_{2}\right](\mathbf{1 5})$ (Figure 8, Table 7) in high yield after subsequent work-up (Scheme 14).

$$
\left(\mathrm{Me}_{3} \mathrm{Si}\right)_{3} \mathrm{CAlMe}_{2} \cdot \mathrm{THF}+\mathrm{TBDAF} \underset{-\mathrm{THF}}{\longrightarrow}\left[\mathrm{nBu}_{4} \mathrm{~N}\right]\left[\left(\mathrm{Me}_{3} \mathrm{Si}\right)_{3} \mathrm{CAlMeF}_{2}\right]+\mathrm{MeH}
$$

\section{Scheme 14}

Compound 15 crystallized with 0.5 molecules of toluene. Crystals used for the analysis of the elements $\mathrm{C}, \mathrm{H}, \mathrm{Al}, \mathrm{F}$, and $\mathrm{N}$ confirm the composition of $\mathrm{C}_{30.5} \mathrm{H}_{70} \mathrm{AlF}_{2} \mathrm{NSi}_{3}$.

In the ${ }^{1} \mathrm{H}$ NMR of $\mathbf{1 5}$ one resonance at $\delta-0.29$ ppm as a triplet with a coupling constant $J=$ $2.8 \mathrm{~Hz}$ and one resonance at $\delta 0.69 \mathrm{ppm}$ for the $\left(\mathrm{Me}_{3} \mathrm{Si}\right)_{3} \mathrm{C}$ ligand are found for the anion in the appropriate ratio of integration in addition to the signals of the cation. 

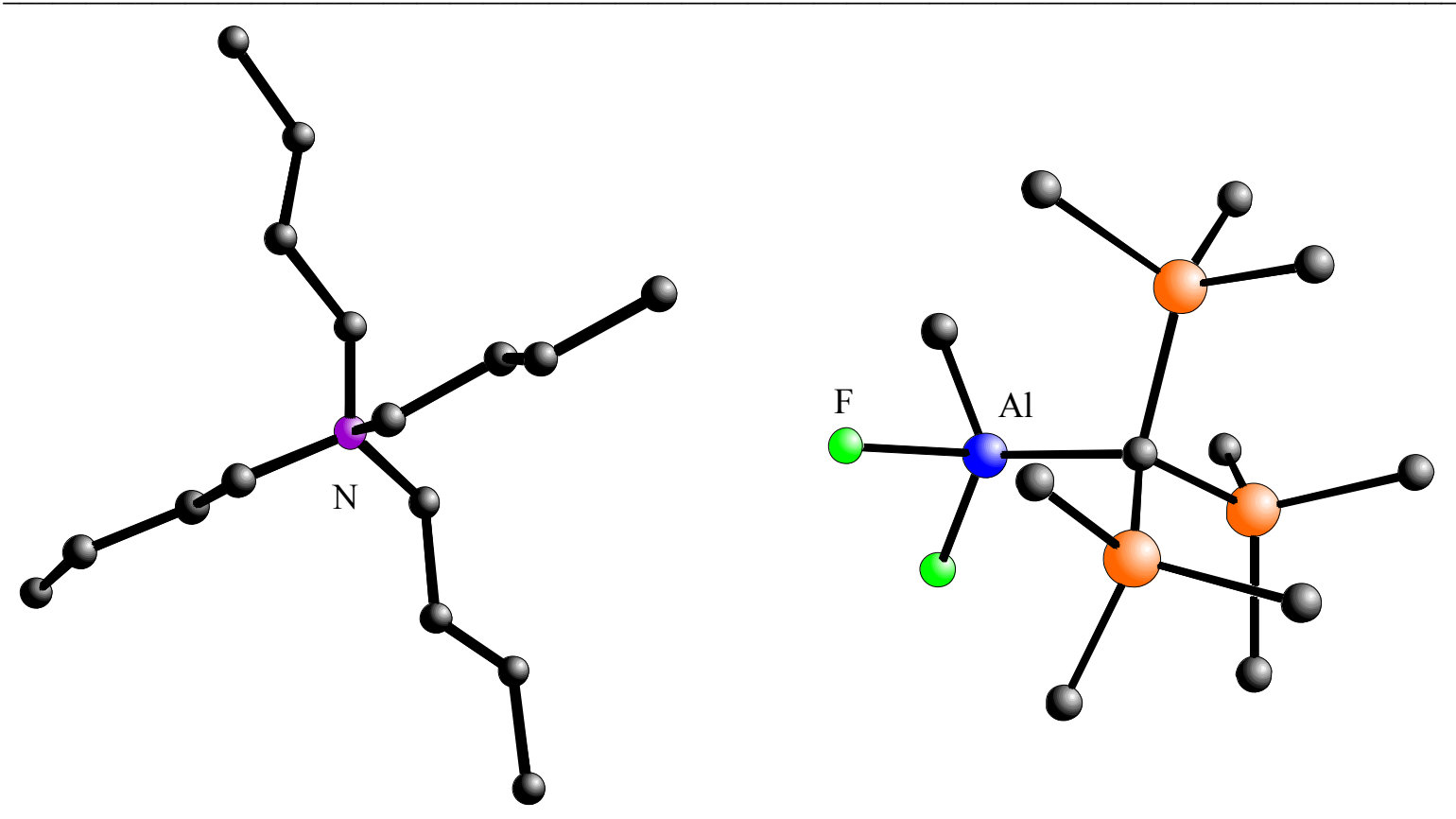

Figure 8. Molecular structure of $\left[n \mathrm{Bu}_{4} \mathrm{~N}\right]\left[\left(\mathrm{Me}_{3} \mathrm{Si}\right)_{3} \mathrm{CAlMeF}_{2}\right] \mathbf{( 1 5 )}$.

Table 7. Selected bond distances $[\AA]$ and angles $\left[{ }^{\circ}\right]$ for $\mathbf{1 5}$ :

$\begin{array}{llll}\mathrm{Al}(1)-\mathrm{C}(1) & 2.010(6) & \mathrm{Al}(1)-\mathrm{F}(1) & 1.702(5) \\ \mathrm{Al}(1)-\mathrm{C}(2) & 1.945(11) & \mathrm{Al}(1)-\mathrm{F}(2) & 1.680(5) \\ & & & \\ \mathrm{F}(1)-\mathrm{Al}(1)-\mathrm{F}(2) & 106.0(3) & \mathrm{F}(2)-\mathrm{Al}(1)-\mathrm{C}(1) & 109.0(3) \\ \mathrm{F}(1)-\mathrm{Al}(1)-\mathrm{C}(1) & 110.6(3) & \mathrm{F}(2)-\mathrm{Al}(1)-\mathrm{C}(2) & 106.4(5) \\ \mathrm{F}(1)-\mathrm{Al}(1)-\mathrm{C}(2) & 107.0(4) & \mathrm{C}(1)-\mathrm{Al}(1)-\mathrm{C}(2) & 117.2(4)\end{array}$

The ${ }^{19} \mathrm{~F}$ NMR spectrum reveals a singlet at $\delta-145.9 \mathrm{ppm}$ shifted downfield from the comparable resonance of $\left[n \mathrm{Bu}_{4} \mathrm{~N}\right]\left[\mathrm{Me}_{2} \mathrm{AlF}_{2}\right](\delta-154.8 \mathrm{ppm})[86]$.

In the negative FAB-MS of $\mathbf{1 5}$, the anion peak is observed (at $\mathrm{m} / \mathrm{z} 311$ ) with $100 \%$ intensity.

The IR spectrum shows two absorptions at 741 and $640 \mathrm{~cm}^{-1}$ attributable to Al-F bond stretches [61]. 
The spectroscopic conclusions were corroborated through an X-ray diffraction study of $\mathbf{1 5}$. Single crystals of $\mathbf{1 5}$ were grown from toluene within one week at $-20{ }^{\circ} \mathrm{C}$. Compound $\mathbf{1 5}$ crystallizes in the monoclinic space group $P 2_{1} / c$. The metal center of the anion has a distorted tetrahedral coordination environment. The average Al-F bond distance in $\mathbf{1 5}(1.690 \AA)$ is somewhat shorter compared to that in $\left[n \mathrm{Bu}_{4} \mathrm{~N}\right]\left[\mathrm{Me}_{2} \mathrm{AlF}_{2}\right](1.712 \AA)$ and somewhat longer than the normal Al-F bonds (1.65 $\AA$ ) [2]. The C-Al-C $\left(117.2(4)^{\circ}\right)$ bond angle of 15 is nearly identical to that of $\left[n \mathrm{Bu}_{4} \mathrm{~N}\right]\left[\mathrm{Me}_{2} \mathrm{AlF}_{2}\right]\left(117.13(10)^{\circ}\right)$ despite the presence of a more sterically demanding ligand in 15; in addition, the F-Al-F bond angle is actually larger in $\mathbf{1 5}\left(106.0(5)^{\circ}\right)$ than that in $\left[n \mathrm{Bu}_{4} \mathrm{~N}\right]\left[\mathrm{Me}_{2} \mathrm{AlF}_{2}\right]\left(103.23^{\circ}\right)$.

The fluoride transfer with TBADF is facile to carry out, and has also been demonstrated in the fluorination of trisubstituted silanes [88].

Following to the herein described difluorodiorganometalates the first phosphonate anions of aluminum - containing fluorine and an anionic bridged fluoroalkoxy derivative of titanium are realized using TBADF as a fluorinating agent [89].

$\left[\mathrm{Me}_{4} \mathrm{~N}\right]\left[(i \mathrm{Bu})_{2} \mathrm{AlF}_{2}\right]$ and $\left[\mathrm{Ph}_{4} \mathrm{P}\right]\left[\mathrm{AlF}_{4}\right]$ have been prepared and characterized by $\mathrm{X}$-ray structure analysis [90] using a similar synthetic approach as described for $\mathbf{1 5}$. These compounds, containing the anions $\left[\mathrm{R}_{2} \mathrm{AlF}_{2}\right]^{-}$and $\left[\mathrm{AlF}_{4}\right]^{-}$, respectively, permitted a comparison of the hard and soft acid and base principle by means of ab-initio calculations. The therein described model allows rationalization of the tendencies of bond angle variation in $\left[\mathrm{R}_{2} \mathrm{MX}_{2}\right]$ systems containing a main group metal $(\mathrm{M})$ in terms of hybridization and correlation with electronegativity and hardness of the ligands. The computed analysis surprisingly reveals that the Al-F bond in the $\left[\mathrm{R}_{2} \mathrm{AlF}_{2}\right]^{-}$anion is weaker than the $\mathrm{Al}-\mathrm{Me}$ bond. 15 contains a large $\mathrm{C}\left(\mathrm{SiMe}_{3}\right)_{3}$ ligand and a small Me group in comparison with the $\left[\mathrm{R}_{2} \mathrm{AlF}_{2}\right]^{-}$ anion described. But these results may account for $\mathbf{1 5}$ too and have to be taken into consideration when bond distances of the anion in $\mathbf{1 5}$ are compared to those in the $\left[\mathrm{Me}_{2} \mathrm{AlF}_{2}\right]^{-}$ anion. The Al-F bond distance in $\mathbf{1 5}$ is $0.02 \AA$ shorter than the corresponding distance in 
$\left[n \mathrm{Bu}_{4} \mathrm{~N}\right]\left[\mathrm{Me}_{2} \mathrm{AlF}_{2}\right]$. This may indicate that the Al-F bonds in $\left[n \mathrm{Bu}_{4} \mathrm{~N}\right]\left[\mathrm{Me}_{2} \mathrm{AlF}_{2}\right]$ are weaker than those in $\mathbf{1 5}$.

\subsection{Reactions of $\left(\mathrm{Me}_{3} \mathrm{Si}\right)_{3} \mathrm{CAlMe}{ }_{2} \cdot \mathrm{THF}$ with $\mathrm{CF}_{3} \mathrm{COOH}$}

Several oxo-centered trinuclear carboxylates of transition metal complexes are described in the literature. On the other hand there are only a few examples of analogous main group compounds characterized by X-ray crystal structural analysis. The first group 13 derivative of this type is $\left[\mathrm{Ga}_{3}\left(\mu_{3}-\mathrm{O}\right)\left(\mu-\mathrm{O}_{2} \mathrm{CC}_{6} \mathrm{H}_{5}\right)_{6}(4-\mathrm{Mepy})_{3}\right]\left[\mathrm{GaCl}_{4}\right](\mathbf{j})\left(\mathrm{R}=\mathrm{O}_{2} \mathrm{CC}_{6} \mathrm{H}_{5}, \mathrm{~L}=4-\mathrm{Mepy}\right)$ (Scheme 15) [91] without precedent for an analogous aluminum compound. Therefore it was interesting to investigate the reaction of a $\left(\mathrm{Me}_{3} \mathrm{Si}\right)_{3} \mathrm{CAlMe} \mathrm{M}_{2} \cdot \mathrm{THF}$ with $\mathrm{CF}_{3} \mathrm{COOH}$.

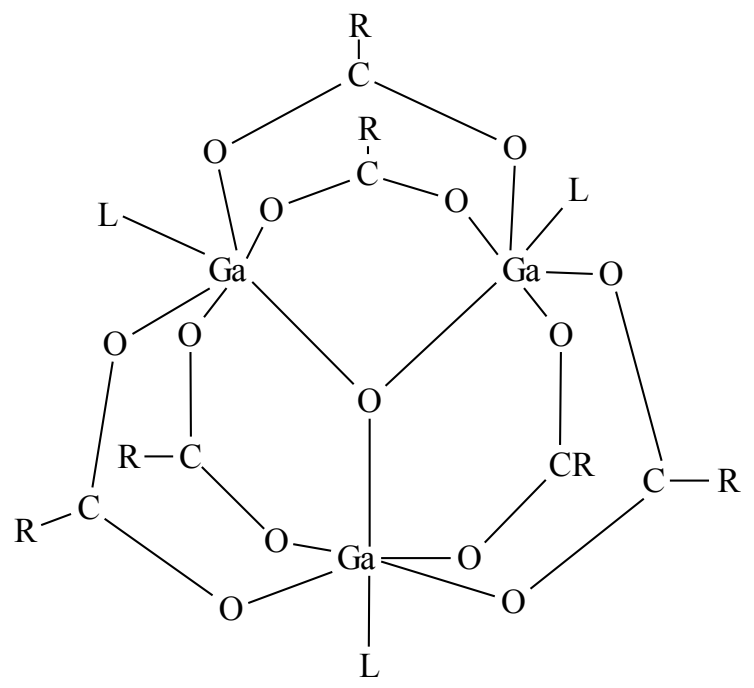

Scheme 15. Drawing of $\left[\mathrm{Ga}_{3}\left(\mu_{3}-\mathrm{O}\right)\left(\mu-\mathrm{O}_{2} \mathrm{CC}_{6} \mathrm{H}_{5}\right)_{6}(4-\mathrm{Mepy})_{3}\right]^{+} . \mathrm{R}=\mathrm{C}_{6} \mathrm{H}_{5} ; \mathrm{L}=4-\mathrm{Mepy}$. 


\subsubsection{Reaction of $\left(\mathrm{Me}_{3} \mathrm{Si}\right)_{3} \mathrm{CAlMe} \cdot \mathrm{THF}$ with $\mathrm{CF}_{3} \mathrm{COOH}$ in a 1 : 1 molar ratio. Synthesis of $\left[\left(\mathrm{Me}_{3} \mathrm{Si}\right)_{3} \mathrm{CAIMe}\left(\mathrm{O}_{2} \mathrm{CCF}_{3}\right)\right]_{2}(16)$}

$\mathrm{CF}_{3} \mathrm{COOH}(1 \mathrm{eq})$ was added to a solution of $\left(\mathrm{Me}_{3} \mathrm{Si}\right)_{3} \mathrm{CAlMe} \mathrm{e}_{2} \cdot \mathrm{THF}$ in toluene. The cloudy liquid was stirred for $1 \mathrm{~d}$. The insoluble residue was filtered off and crystallized at $-20{ }^{\circ} \mathrm{C}$ from THF. Small amounts of adherent solvent were removed in vacuo. The colorless solid decomposes at $210^{\circ} \mathrm{C}$.

The analyses of $\mathbf{1 6}$ for the elements $\mathrm{C}$ and $\mathrm{H}$ confirm the required composition $\mathrm{C}_{26} \mathrm{H}_{60} \mathrm{Al}_{2} \mathrm{~F}_{6} \mathrm{O}_{4} \mathrm{Si}_{6}$.

The ${ }^{1} \mathrm{H}$ NMR (THF- $\mathrm{d}_{8}$ ) shows resonances for the protons of an aluminum bounded methyl group at $\delta-0.47 \mathrm{ppm}$ and for the protons of the $\mathrm{C}\left(\mathrm{SiMe}_{3}\right)_{3}$ ligand at $\delta 0.23 \mathrm{ppm}$. The relation of the integrals $(3: 27)$ reveals the generation of a compound of composition $\left(\mathrm{Me}_{3} \mathrm{Si}\right)_{3} \mathrm{C}$ $\mathrm{AlMe}\left(\mathrm{O}_{2} \mathrm{CCF}_{3}\right)$.

Only one $(\delta-74.7 \mathrm{ppm})$ resonance for the fluorine atoms of the $\mathrm{CF}_{3}$ group is observed in the ${ }^{19}$ F NMR spectrum.

The EI mass spectrum shows a peak assignable to a $\left(\mathrm{Me}_{3} \mathrm{Si}\right)_{3} \mathrm{CAl}\left(\mathrm{O}_{2} \mathrm{CCF}_{3}\right)$ fragment $(\mathrm{at} \mathrm{m} / \mathrm{z}$ $371)$ with $100 \%$ intensity. Another peak (at $\left.m / z, 757,\left[\left(\mathrm{Me}_{3} \mathrm{Si}\right)_{3} \mathrm{CAlMe}\left(\mathrm{O}_{2} \mathrm{CCF}_{3}\right)\right]_{2}-\mathrm{Me}\right)$ with $30 \%$ intensity is indicative for the dimeric nature of $\mathbf{1 6}$.

Attemps to grow crystals for X-ray structural analysis to prove the configuration were not successful. (Scheme 16). 


\subsubsection{Reaction of $\left(\mathrm{Me}_{3} \mathrm{Si}\right)_{3} \mathrm{CAlMe} \mathrm{C}_{2} \cdot \mathrm{THF}$ with $\mathrm{CF}_{3} \mathrm{COOH}$ in a 1 : 2 molar ratio. Synthesis of $\left[\left(\mathrm{Me}_{3} \mathrm{Si}\right)_{3} \mathrm{CAl}\left(\mathrm{O}_{2} \mathrm{CCF}_{3}\right)_{2}\right]_{2}(17)$}

$\mathrm{CF}_{3} \mathrm{COOH}$ (1 eq) was added to a solution of $\left(\mathrm{Me}_{3} \mathrm{Si}\right)_{3} \mathrm{CAlMe} \mathrm{e}_{2} \cdot \mathrm{THF}$ in toluene (Scheme 16). The same cloudy liquid originated as observed for the reaction described in 2.8.1. Addition of a second equivalent $\mathrm{CF}_{3} \mathrm{COOH}$ (1 eq) produced a clear solution which was stirred for $1 \mathrm{~d}$. All solvents were evaporated in vacuo. The residue was treated with $n$ hexane $(20 \mathrm{~mL})$ and filtered. The insoluble residue was dissolved in toluene and crystallized at $-20^{\circ} \mathrm{C}$. A colorless solid (45\%) was isolated which decomposes at $170{ }^{\circ} \mathrm{C}$.

The elemental analyses of $\mathbf{1 7}$ for $\mathrm{C}$ and $\mathrm{H}$ confirm the composition $\mathrm{C}_{28} \mathrm{H}_{54} \mathrm{Al}_{2} \mathrm{~F}_{12} \mathrm{O}_{8} \mathrm{Si}_{6}$.

The ${ }^{1} \mathrm{H}$ NMR $\left(\mathrm{THF}-\mathrm{d}_{8}\right)$ spectrum contains only one resonance for the protons of the $\mathrm{C}\left(\mathrm{SiMe}_{3}\right)_{3}$ ligand at $\delta 0.23 \mathrm{ppm}$.

The resonances for the fluorine atoms in the ${ }^{19} \mathrm{~F}$ spectrum are observed at $\delta-74.8 \mathrm{ppm}$.

In the EI mass spectrum the $100 \%$ peak due to the fragment $\left[\left(\mathrm{Me}_{3} \mathrm{Si}\right)_{3} \mathrm{CAl}_{(}\left(\mathrm{O}_{2} \mathrm{CCF}_{3}\right)_{2}\right]_{2}-\mathrm{Me}$ $(\mathrm{m} / \mathrm{z}$ 953) is observed which provides evidence for a dimeric composition, but a trimeric aggregate cannot be ruled out ultimatively.

Up to now it was not possible to grow suitable crystals for an X-ray structural analysis to unravel the configuration of $\left[\left(\mathrm{Me}_{3} \mathrm{Si}\right)_{3} \mathrm{CAl}\left(\mathrm{O}_{2} \mathrm{CCF}_{3}\right)_{2}\right]_{2}$.

$$
\begin{aligned}
& 2\left(\mathrm{Me}_{3} \mathrm{Si}\right)_{3} \mathrm{CAlMe}{ }_{2} \cdot \mathrm{THF}+2 \mathrm{CF}_{3} \mathrm{COOH} \underset{-2 \mathrm{THF}}{\longrightarrow}\left[\left(\mathrm{Me}_{3} \mathrm{Si}\right)_{3} \mathrm{CAlMe}_{2}\left(\mathrm{O}_{2} \mathrm{CCF}_{3}\right)\right]_{2}+2 \mathrm{MeH} \quad \mathbf{1 6} \\
& 2\left(\mathrm{Me}_{3} \mathrm{Si}\right)_{3} \mathrm{CAlMe} \cdot \mathrm{THF}+4 \mathrm{CF}_{3} \mathrm{COOH} \underset{-2 \mathrm{THF}}{\longrightarrow}\left[\left(\mathrm{Me}_{3} \mathrm{Si}\right)_{3} \mathrm{CAl}\left(\mathrm{O}_{2} \mathrm{CCF}_{3}\right)_{2}\right]_{2}+4 \mathrm{MeH} \quad \mathbf{1 7} \\
& 4\left(\mathrm{Me}_{3} \mathrm{Si}\right)_{3} \mathrm{CAlMe}{ }_{2} \cdot \mathrm{THF}+11 \mathrm{CF}_{3} \mathrm{COOH} \underset{-\mathrm{THF}}{\longrightarrow}\left[\left(\mathrm{Al}_{3}\left(\mu_{3}-\mathrm{O}\right)\left(\mu-\mathrm{O}_{2} \mathrm{CCF}_{3}\right)_{6}(\mathrm{THF})_{3}\right]^{+} \quad \mathbf{1 8}\right. \\
& \begin{array}{l}
{\left[\left(\mathrm{Me}_{3} \mathrm{Si}\right)_{3} \mathrm{CAl}\left(\mathrm{OC}(\mathrm{O}) \mathrm{CF}_{3}\right)_{3}\right]^{-}} \\
+8 \mathrm{MeH}+3\left(\mathrm{Me}_{3} \mathrm{Si}\right)_{3} \mathrm{CH}+\left(\mathrm{CF}_{3} \mathrm{CO}\right)_{2} \mathrm{O}
\end{array}
\end{aligned}
$$

\section{Scheme 16}




\subsubsection{Reaction of $\left(\mathrm{Me}_{3} \mathrm{Si}\right)_{3} \mathrm{CAlMe} \cdot \mathrm{THF}$ with $\mathrm{CF}_{3} \mathrm{COOH}$ in a 1 : 3 molar ratio. Synthesis of $\left[\mathrm{Al}_{3}\left(\mu_{3}-\mathrm{O}\right)\left(\mu-\mathrm{O}_{2} \mathrm{CCF}_{3}\right)_{6}(\mathrm{THF})_{3}\right]^{+}\left[\left(\mathrm{Me}_{3} \mathrm{Si}\right)_{3} \mathrm{CAl}\left(\mathrm{OC}(\mathrm{O}) \mathrm{CF}_{3}\right)_{3}\right]^{-}(18)$}

$\mathrm{CF}_{3} \mathrm{COOH}$ (3 eq) was added to a solution of $\left(\mathrm{Me}_{3} \mathrm{Si}\right)_{3} \mathrm{CAlMe} \cdot \mathrm{THF}$ in toluene and stirred for $1 \mathrm{~d}$. All volatile substances were pumped off. The residue was dissolved in toluene/THF (5:1). Crystallization at $-20{ }^{\circ} \mathrm{C}$ afforded $\mathbf{1 8}$ (Scheme 16) in low yield after 2 weeks (decomposing at $135^{\circ} \mathrm{C}$ ).

18 crystallized together with one molecule of toluene. These crystals were used for the elemental analysis of $\mathrm{C}$ and $\mathrm{H}$ and confirm the composition $\mathrm{C}_{47} \mathrm{H}_{59} \mathrm{Al}_{4} \mathrm{~F}_{27} \mathrm{O}_{22} \mathrm{Si}_{3}$.

The NMR spectra were recorded in THF- $\mathrm{d}_{8}$, though 18 may decompose in this solvent.

In the ${ }^{1} \mathrm{H}$ NMR spectrum one resonance at $\delta 0.26 \mathrm{ppm}$ and one small signal at $\delta 0.48 \mathrm{ppm}$ are observed.

The resonances of the fluorine atoms in the ${ }^{19} \mathrm{~F}$ NMR spectrum appear at $\delta-77.4,-75.9$ and $-75.8 \mathrm{ppm}$.

In the FAB-MS of $\mathbf{1 8}$, the peak for the cation $\left[\mathrm{Al}_{3}\left(\mu_{3}-\mathrm{O}\right)\left(\mu-\mathrm{O}_{2} \mathrm{CCF}_{3}\right)_{6}(\mathrm{THF})_{3}\right]^{+}$is observed (at

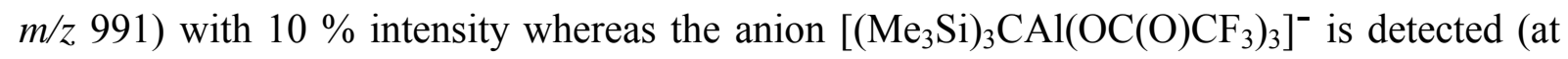
$m / z, 597)$ with $100 \%$ intensity.

Suitable single crystals for an X-ray structural analysis of $\mathbf{1 8}$ (Figure 9 and 10, Table 8) were obtained from a saturated toluene/THF solution $(8: 1)$ at $-20{ }^{\circ} \mathrm{C}$. The molecular structure of the complex cation is shown in Figure 9. The central $\mathrm{Al}_{3} \mathrm{O}$ part consists of a planar triangular arrangement of aluminum atoms $\left(120^{\circ}\right)$. Each aluminum atom possesses a slightly distorted octahedral coordination sphere. The $\mu_{3}-\mathrm{O}$ atom shows equidistances $(1.8529(11) \AA)$ to the three aluminum centers which is somewhat longer than those in $\mathrm{Pb}_{2} \mathrm{Al}_{5}\left(\mu_{3}-\mathrm{O}\right)\left(\mu_{4}-\mathrm{O}\right)$ $(\mu-\mathrm{O} i \mathrm{Pr})_{9}(\mathrm{O} i \mathrm{Pr})_{3}(\mu-\mathrm{OAc})_{3}\left(\mathrm{Al}-\left(\mu_{3}-\mathrm{O}\right) 1.822 \AA\right)$ [92]. The aluminum oxygen (THF) distances $(1.948(3) \AA)$ in $\mathbf{1 8}$ are somewhat longer than those in $\left[\left(2,6-i \mathrm{Pr}_{2} \mathrm{C}_{6} \mathrm{H}_{3}\right) \mathrm{N}\left(\mathrm{SiMe}_{2} i \mathrm{Pr}\right)-\right.$ $\left.\mathrm{SiO}_{3} \mathrm{Al} \cdot \mathrm{THF}\right]_{4}(1.866 \AA$ ) [93]. The aluminum oxygen (carboxylate) distances (av $1.892 \AA$ ) in the solid state cation are somewhat shorter than those of the coordinated oxygen atoms of 
THF in 18. The aluminum oxygen distances in the anion of $\mathbf{1 8}$ (Figure 10) are short (178.4(3) $\AA$ ) compared to those of the cation of $\mathbf{1 8}$. The coordination sphere at the aluminum in the anion has a slightly distorted tetrahedral environment.

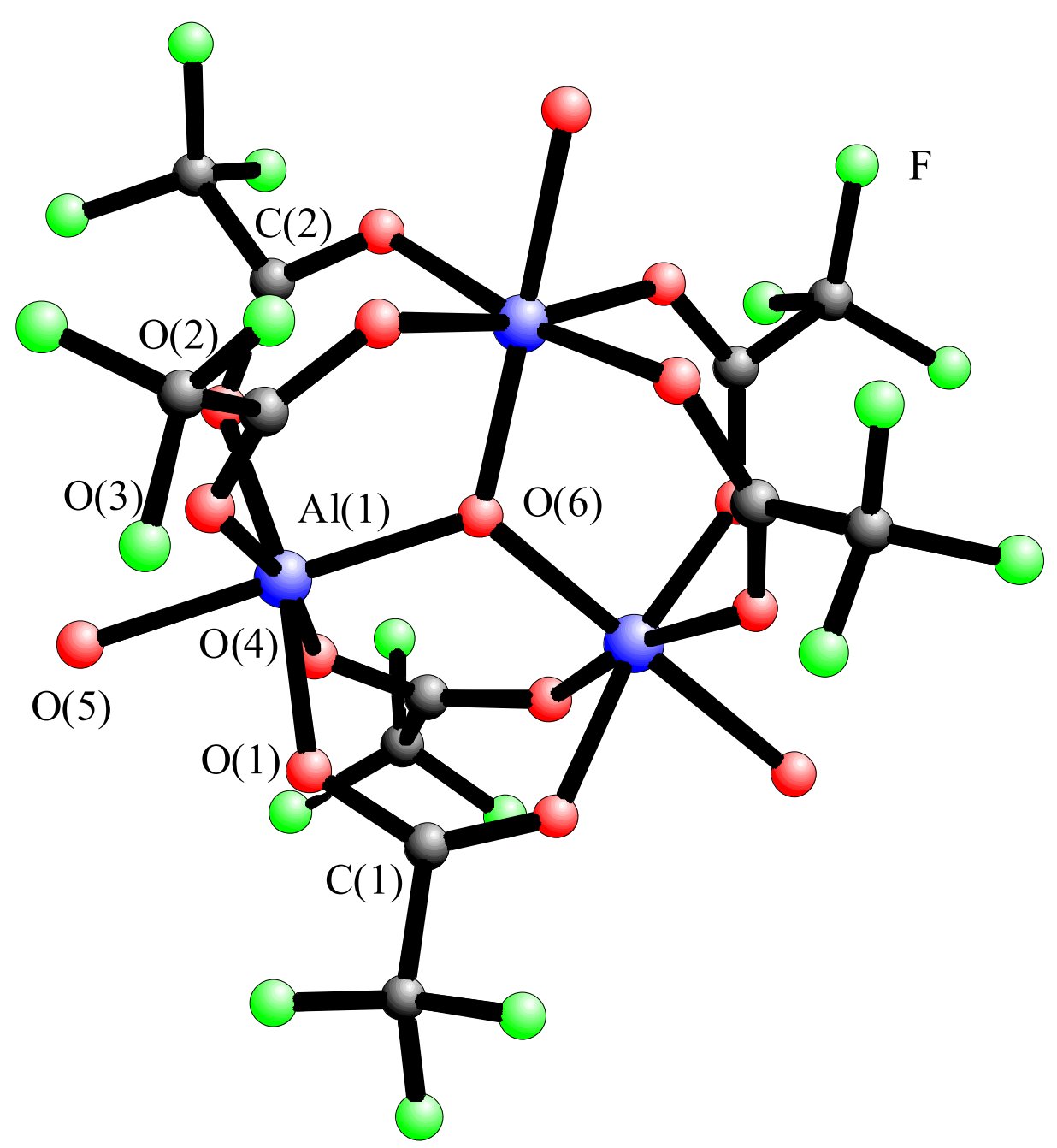

Figure 9. Molecular structure of the $\left[\mathrm{Al}_{3}\left(\mu_{3}-\mathrm{O}\right)\left(\mu-\mathrm{O}_{2} \mathrm{CCF}_{3}\right)_{6}(\mathrm{THF})_{3}\right]^{+}$cation of 18. Only the ipso oxygen atoms of THF are displayed.

The stepwise formation of compounds $\mathbf{1 6 - 1 8}$ can be rationalized as follows:

The first step is the exchange of a methyl group by $\mathrm{CF}_{3} \mathrm{COO}^{-}$followed by replacement of the second methyl by a second $\mathrm{CF}_{3} \mathrm{COO}^{-}$. Inadvertently present water or water generated from condensation of $\mathrm{CF}_{3} \mathrm{COOH}$ in this strongly acidic solution then accounts for the cleavage of 
the remaining Al-C bonds under formation of the cation. The anion results from addition of $\mathrm{CF}_{3} \mathrm{COO}^{-}$to 17 .

18 is the first X-ray structurally characterized oxo-centered trinuclear carboxylate of aluminum.

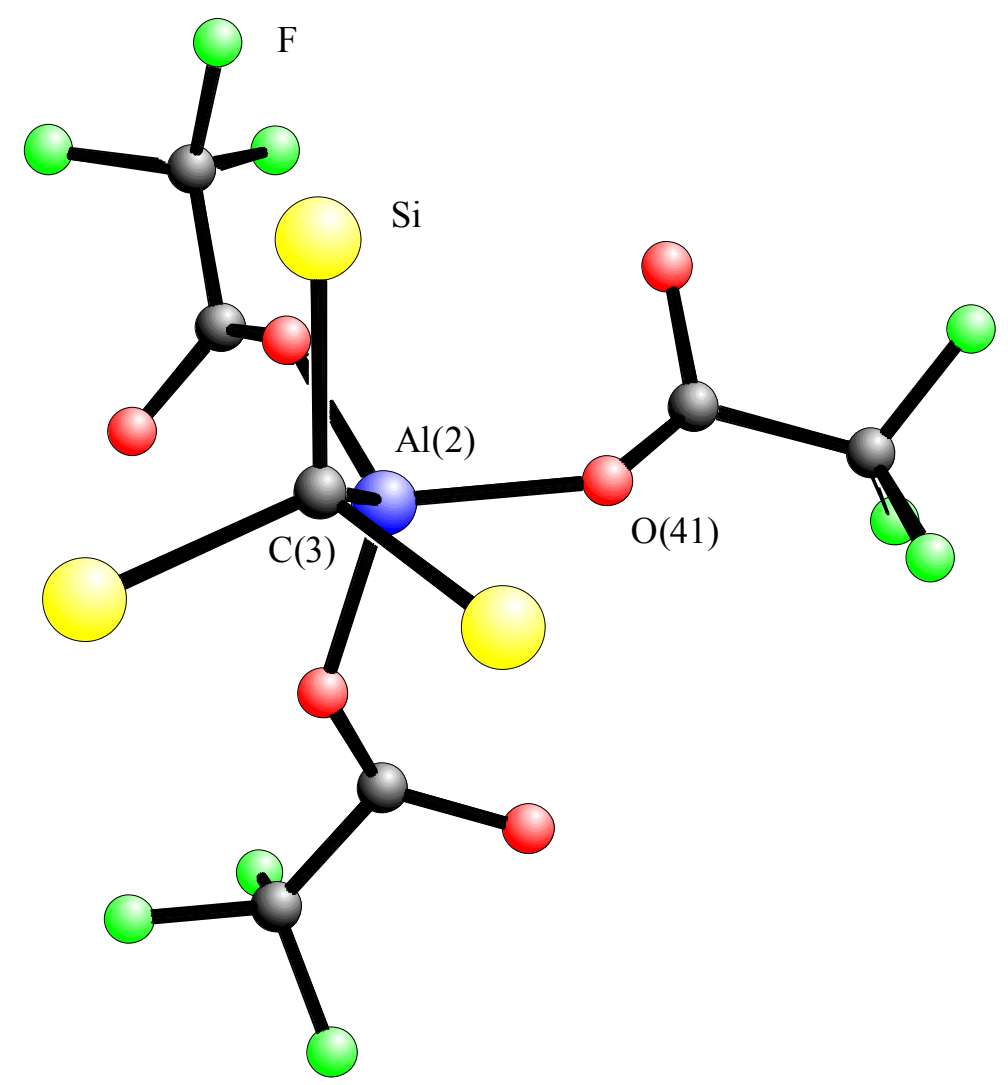

Figure 10. Molecular structure of the $\left[\left(\mathrm{Me}_{3} \mathrm{Si}\right)_{3} \mathrm{CAl}\left(\mathrm{OC}(\mathrm{O}) \mathrm{CF}_{3}\right)_{3}\right]^{-}$anion of 18. Me groups are omitted for clarity.

Table 8. Selected bond distances $[\AA]$ and angles $\left[{ }^{\circ}\right]$ for $\mathbf{1 8 .}$

$\begin{array}{lllr}\mathrm{Al}(1)-\mathrm{O}(1) & 189.0(3) & \mathrm{O}(1)-\mathrm{C}(1) & 123.5(5) \\ \mathrm{Al}(1)-\mathrm{O}(3) & 189.5(3) & \mathrm{O}(2)-\mathrm{C}(2) & 123.2(4) \\ \mathrm{Al}(1)-\mathrm{O}(6) & 185.29(11) & \mathrm{Al}(2)-\mathrm{O}(41) & 178.4(3) \\ \mathrm{Al}(1)-\mathrm{O}(5) & 194.8(3) & \mathrm{Al}(2)-\mathrm{C}(3) & 195.9(7) \\ \mathrm{C}(1)-\mathrm{O}(3) \# 2 & 123.0(5) & & \end{array}$




$\begin{array}{lrlr}\mathrm{O}(6)-\mathrm{Al}(1)-\mathrm{O}(2) & 95.77(12) & \mathrm{O}(1)-\mathrm{Al}(1)-\mathrm{O}(5) & 84.16(12) \\ \mathrm{O}(6)-\mathrm{Al}(1)-\mathrm{O}(1) & 95.27(13) & \mathrm{O}(4)-\mathrm{Al}(1)-\mathrm{O}(5) & 84.53(11) \\ \mathrm{O}(2)-\mathrm{Al}(1)-\mathrm{O}(1) & 168.95(13) & \mathrm{O}(3)-\mathrm{Al}(1)-\mathrm{O}(5) & 84.84(12) \\ \mathrm{O}(6)-\mathrm{Al}(1)-\mathrm{O}(4) & 95.31(12) & \mathrm{C}(1)-\mathrm{O}(1)-\mathrm{Al}(1) & 131.5(3) \\ \mathrm{O}(2)-\mathrm{Al}(1)-\mathrm{O}(4) & 87.57(13) & \mathrm{C}(2)-\mathrm{O}(2)-\mathrm{Al}(1) & 130.9(2) \\ \mathrm{O}(1)-\mathrm{Al}(1)-\mathrm{O}(4) & 91.70(15) & \mathrm{Al}(1)-\mathrm{O}(6)-\mathrm{Al}(1) \# 1 & 119.999(2) \\ \mathrm{O}(6)-\mathrm{Al}(1)-\mathrm{O}(3) & 95.30(12) & \mathrm{O}(3) \# 2-\mathrm{C}(1)-\mathrm{O}(1) & 127.3(4) \\ \mathrm{O}(2)-\mathrm{Al}(1)-\mathrm{O}(3) & 92.14(14) & \mathrm{O}(3) \# 2-\mathrm{C}(1)-\mathrm{C}(11) & 117.3(4) \\ \mathrm{O}(1)-\mathrm{Al}(1)-\mathrm{O}(3) & 86.54(16) & \mathrm{O}(1)-\mathrm{C}(1)-\mathrm{C}(11) & 115.4(4) \\ \mathrm{O}(4)-\mathrm{Al}(1)-\mathrm{O}(3) & 169.36(13) & \mathrm{O}(2)-\mathrm{C}(2)-\mathrm{C}(21) & 116.8(3) \\ \mathrm{O}(6)-\mathrm{Al}(1)-\mathrm{O}(5) & 179.40(11) & \mathrm{O}(41)-\mathrm{Al}(2)-\mathrm{O}(41) \# 1 & 106.11(13) \\ \mathrm{O}(2)-\mathrm{Al}(1)-\mathrm{O}(5) & 84.80(11) & \mathrm{O}(41)-\mathrm{Al}(2)-\mathrm{C}(3) & 112.66(12)\end{array}$

Infrared spectrum of 18 (Table 9) [94]:

The infrared spectra of $\mathbf{1 6}, \mathbf{1 7}$, and $\mathbf{1 8}$, between 1100 and $3300 \mathrm{~cm}^{-1}$, are dominated by bands attributable to the organic part of these compounds.

A monodentate acetate group is expected to have a carbon-oxygen bond with an enhanced double bond character $\left(v 1600-1750 \mathrm{~cm}^{-1}\right)$. Two bands $\left(v 1763 \mathrm{~cm}^{-1}, 1735 \mathrm{~cm}^{-1}\right)$ are characteristic for asymmetric COO-valence stretches in the anion of 18. Bands at $v 1400$ $1550 \mathrm{~cm}^{-1}$ indicate acetate groups which coordinate to identical metal atoms (18: $v 1521$ $\left.\mathrm{cm}^{-1}\right)$. It is not possible to discern if an acetate is bidentate coordinated to one metal atom or bridged to two identical atoms [41]. The difference of this stretches $\left(\Delta v \approx 200 \mathrm{~cm}^{-1}\right)$ indicates the existence of monodentate and bidentate $\mathrm{CF}_{3} \mathrm{COO}^{-}$groups. The absorption at $v 663 \mathrm{~cm}^{-1}$ of 18 has been tentatively assigned to an asymmetric stretch of the $\mathrm{M}_{3} \mathrm{O}$ unit $\left(\left[\mathrm{Ga}_{3}\left(\mu_{3}-\mathrm{O}\right)\right.\right.$ $\left.\left.\left(\mu-\mathrm{O}_{2} \mathrm{CC}_{6} \mathrm{H}_{5}\right)_{6}(4-\mathrm{Mepy})_{3}\right]\left[\mathrm{GaCl}_{4}\right]: v 655 \mathrm{~cm}^{-1}\right)$. The band at $v 566 \mathrm{~cm}^{-1}$ of 18 occurs in almost all trimeric carboxylates $\left(v 550 \mathrm{~cm}^{-1}\right)$ and is assigned to a carboxylate mode [91]. 
Table 9. Bands in the infrared spectra of 16, 17, and 18. (Tentatively assignment)
16
17
18

\begin{tabular}{|c|c|c|c|}
\hline 1732 & 1758 & 1763,1735 & $v_{\mathrm{as}} \mathrm{COO}, \mathrm{COO}$ valence vibration \\
\hline 1699 & 1690,1668 & & COO valence vibration \\
\hline & & 1521 & COO valence vibration \\
\hline 1207 & 1260,1220 & 1236,1207 & $v_{\mathrm{as}} \mathrm{C}-\mathrm{F}, v_{\mathrm{s}} \mathrm{C}-\mathrm{C}$ \\
\hline 1170,1077 & 1168 & 1179,1170 & $v_{\mathrm{s}} \mathrm{C}-\mathrm{F}$ \\
\hline & & 1008 & \\
\hline 857 & 857 & 860,803 & \\
\hline 722 & 724 & 735 & \\
\hline 672 & 675 & 663 & $\nu_{\mathrm{as}} \mathrm{Al}-\mathrm{C}$ \\
\hline & & 566 & band of trimeric carboxylate \\
\hline & & 452 & $\delta \mathrm{MO}_{4}$ \\
\hline
\end{tabular}

\subsubsection{Electron Density Calculations for 18}

18 offers an interesting insight into the bonding of the trinuclear frame. Al(III) as a light and diamagnetic ion is a study case, where the coordination bonds of carboxylate and oxo ligands can be analyzed free from the complicated effects of unpaired electrons on the metal ions, as in the case for transition metal systems. The cation of $\mathbf{1 8}$ is a model complex for the coordination in the class of oxo-centered trinuclear compounds $[95,96]$. 


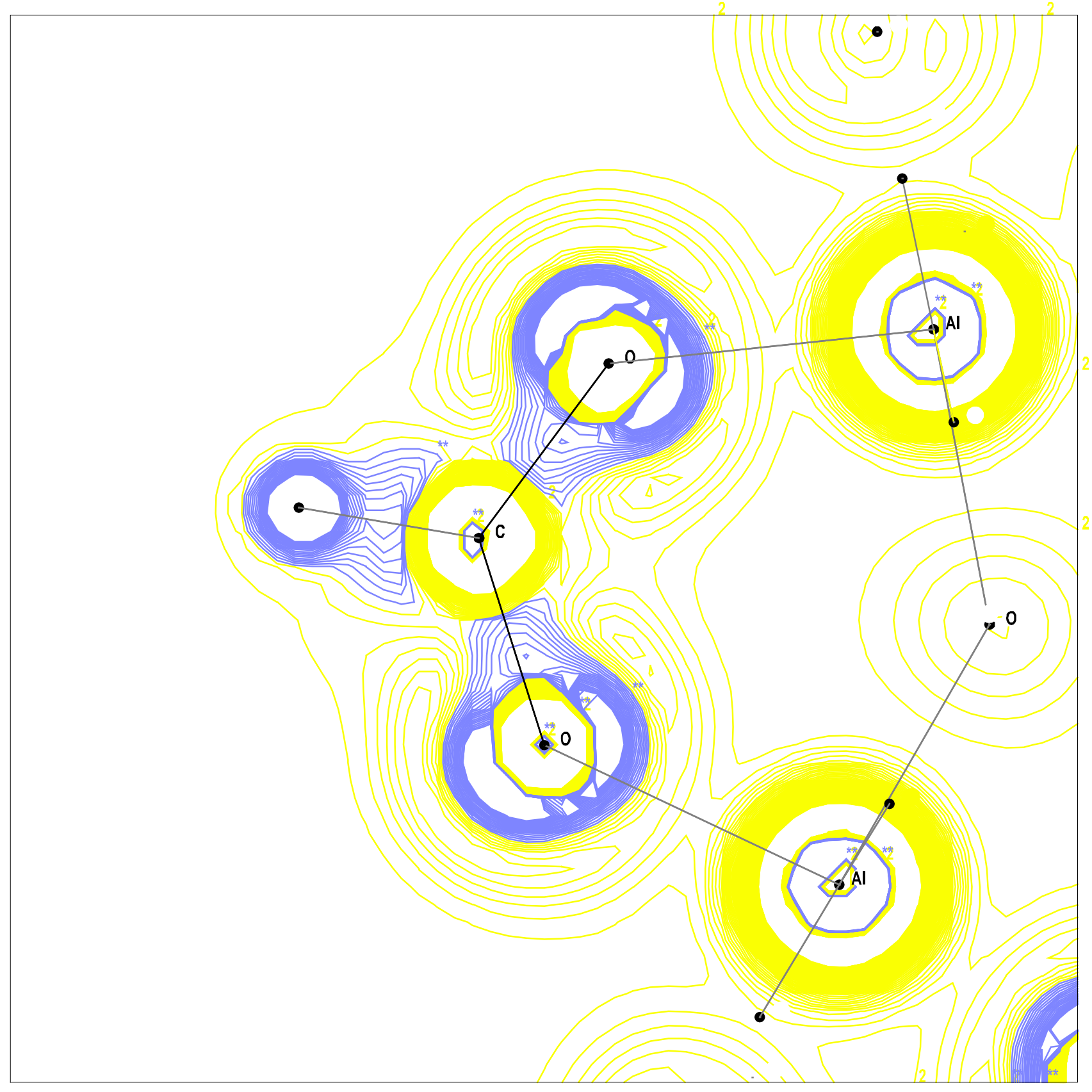

Figure 11. The Laplacian of electron density in one Al-carboxylate-Al coordination plane.

The dark contours represent charge accumulation (lone pairs at oxygen and the C-O bonds) and the light ones the charge deficient zones (empty shells of the Al(III) ions) [95]. 
The actual computational analysis is a preliminary test for a hypothetical structure with formiate, $\left[\mathrm{Al}_{3}\left(\mu_{3}-\mathrm{O}\right)\left(\mu-\mathrm{O}_{2} \mathrm{CH}\right)_{6}\left(\mathrm{H}_{2} \mathrm{O}\right)_{3}\right]^{+}$. The accuracy of the quantum calculations is moderate due to the use of a non expansive low level 3-21G basis set [95,97-99].

A distinguished feature of the structure is the oxo ligand (Figure $11+12$ ). The preliminary investigations on the hypothetical molecule $\left[\mathrm{Al}_{3}\left(\mu_{3}-\mathrm{O}\right)\left(\mu-\mathrm{O}_{2} \mathrm{CH}\right)_{6}\left(\mathrm{H}_{2} \mathrm{O}\right)_{3}\right]^{+}$indicate $\mathrm{sp}^{2}$ hybridization and increased electron density for the oxygen atom in the center. This will probably be the same for $\mathbf{1 8}$. The Laplacian map in the $\mathrm{Al}_{3} \mathrm{O}$ plane (Figure 12) shows the accumulation of electron density in the slightly deformed trigonal shape. The relatively small trigonal deformation of charge accumulated in the plane of the central oxygen can be interpreted as illustrating the hard nature of this ligand [95].

The orientation of the oxygen $\pi$ orbitals of the carboxylate group (Figure 11, bright sphere around the formiate oxygens) is expected to be different in density calculations for $\mathbf{1 8}$ because the orientation of the oxygen $\pi$ orbitals is a function of the group $\mathrm{R}$ of the carboxylate $\left(\mathrm{RCOO}^{-}\right)$[95].

The crystallographic data reveal a disorder in one of the $\mathrm{CF}_{3}$-groups in the cation which causes some problems in the electron density calculations. It was not yet possible to complete the calculation prior to completion of this thesis.

The acetate groups of the anion are totally disordered and not useful for electron density calculations [95].

In conclusion it has been shown that the cation of $\mathbf{1 8}$ is useful for simplified electron density calculations and can serve as a model compound to understand the bonding situation in innumerable analogue transition metal complexes in the class of oxo-centered trinuclear compounds . 


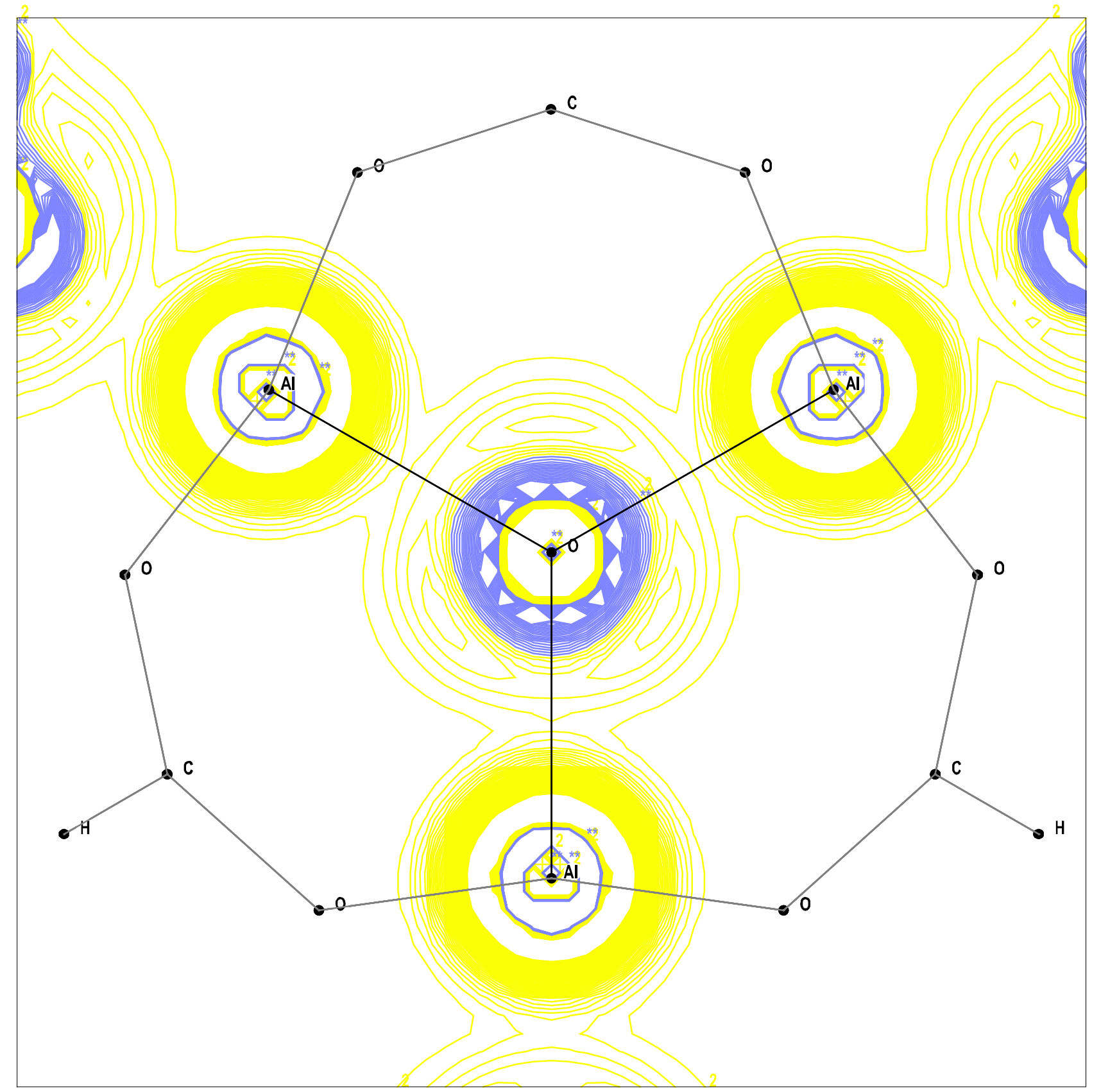

Figure 12. The Laplacian of electron density in the $\left(\mathrm{Al}_{3} \mathrm{O}\right)$ coordination plane.

The dark area in the center represents the electron rich $\mu_{3}-\mathrm{O}$ atom. The valence shell of aluminum is electron deficient (ionized metal). At the aluminum atoms two inner circular zones corresponding to the $2 \mathrm{~s} 2 \mathrm{p}$ and $1 \mathrm{~s}$ core shells are distinguishable [95].

According to the bond order values, the strength of the ligand is the central oxo bridged carboxylate terminal ligand. The central oxygen seems to be strongly involved in $\pi$ donation, a factor that stabilizes the planar symmetry of the $\left(\mathrm{Al}_{3} \mathrm{O}\right)$ skeleton [95]. 


\section{Summary and Outlook}

\subsection{Summary}

The scope and aim of this work was the synthesis of complexes with relevance to ZieglerNatta catalysts $\left[\mathrm{Cp}_{2-\mathrm{y}} \mathrm{ZrX}_{1+\mathrm{y}}\right]\left(\mu-\mathrm{X}^{\prime}\right)\left[\mathrm{RAlF}_{2}\right]\left(\mathrm{Cp}^{\prime}=\mathrm{Cp}\right.$ or substituted $\mathrm{Cp} ; \mathrm{X}, \mathrm{X}^{\prime}=\mathrm{Me}, \mathrm{Cl}$ or $\mathrm{F} ; \mathrm{R}=$ ligand; $\mathrm{y}=0$ or 1 ), the generation of new bimetallic organoaluminum fluorides, access to new organoaluminum fluorides and to investigate the reaction of $\left(\mathrm{Me}_{3} \mathrm{Si}\right)_{3} \mathrm{CAlMe} 2 \cdot \mathrm{THF}$ with $\mathrm{CF}_{3} \mathrm{COOH}$.

The objective to synthesize Ziegler-Natta-Catalysis relevant systems was achieved by the synthesis of $\left[\mathrm{Cp}_{2} \mathrm{ZrMe}\right](\mu-\mathrm{F})\left[\mathrm{F}_{2} \mathrm{AlC}\left(\mathrm{SiMe}_{3}\right)_{3}\right](\mathbf{7})$.

$$
\left[\left(\mathrm{Me}_{3} \mathrm{Si}\right)_{3} \mathrm{CAlF}_{2}\right]_{3}+3 \mathrm{Cp}_{2} \mathrm{ZrMeF} \longrightarrow 3\left[\mathrm{Cp}_{2} \mathrm{ZrMe}\right](\mu-\mathrm{F})\left[\mathrm{F}_{2} \mathrm{AlC}\left(\mathrm{SiMe}_{3}\right)_{3}\right]
$$

An experiment demonstrated that 7 possesses no significant catalytic activity in the polymerization of ethene. The crystallization of 7 from THF produced compound $\left[\mathrm{Cp}_{2} \mathrm{Zr}(\mu-\mathrm{F})_{2} \mathrm{FAlC}\left(\mathrm{SiMe}_{3}\right)_{3}\right]_{2} \mathrm{O}(\mathbf{8})$.

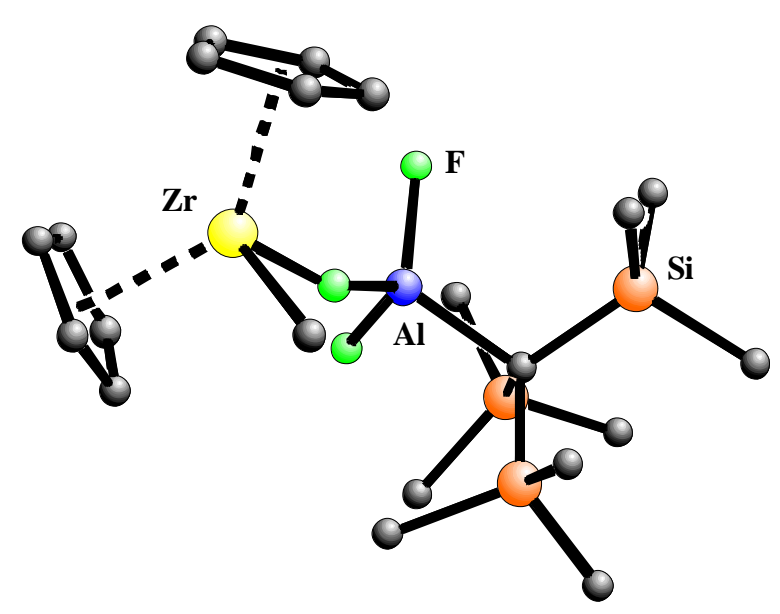

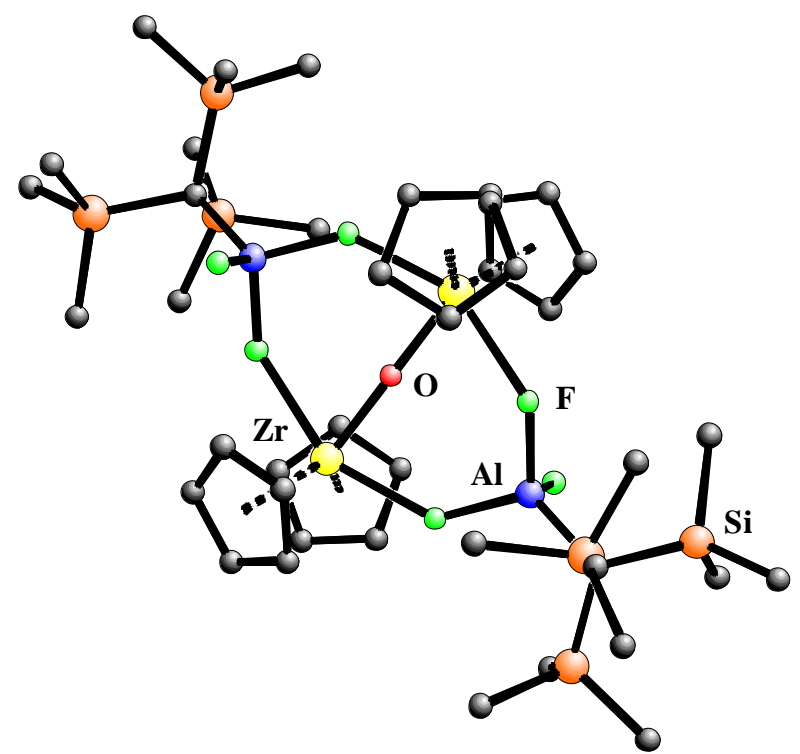

8 
The compounds 9, 10, 11 and $\mathbf{1 2}$ are new bimetallic organoaluminum fluorides.

Compound 9 was generated by using an excess of in situ generated $\mathrm{NaF}$ on $\left[\left(\mathrm{Me}_{3} \mathrm{Si}_{3} \mathrm{CAlF}_{2}\right]_{3}\right.$ in THF and is isostructural with $\left[\mathrm{Li}\left(\mathrm{Me}_{3} \mathrm{Si}_{3} \mathrm{CAlF}_{3}(\mathrm{THF})\right]_{4}[45]\right.$. The central core consists of a cube formed of alternating aluminum and sodium atoms at the edges bridged by fluorine atoms.

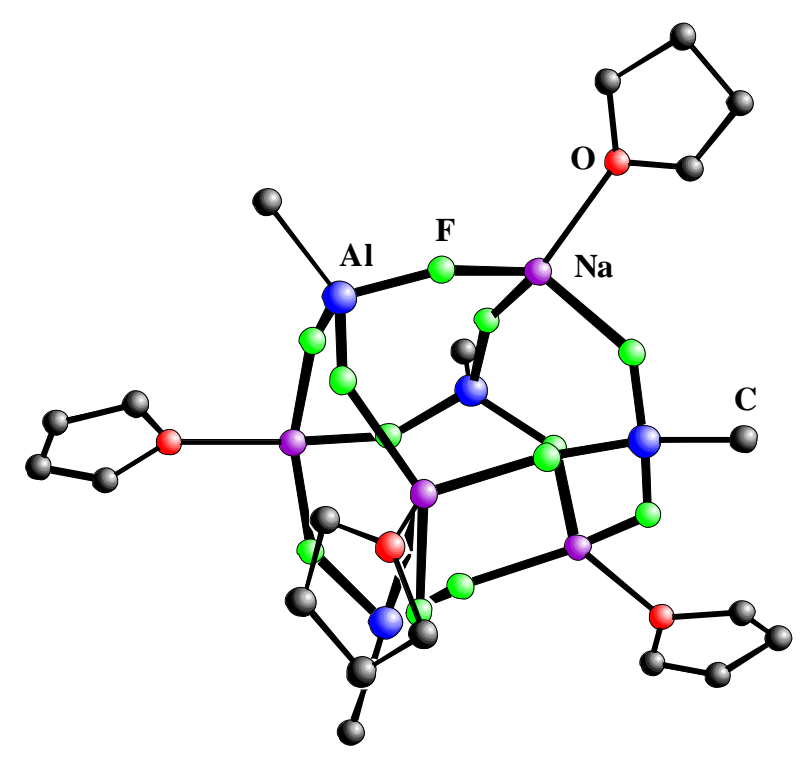

9

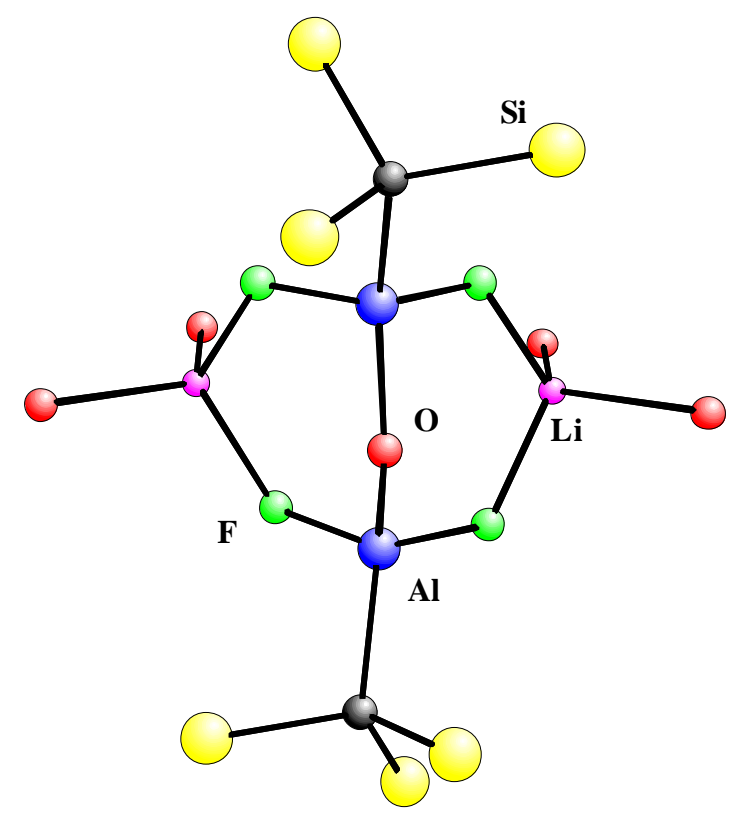

10

Two different synthetic routes have been developed for 10. The $\left[\left(\mathrm{Me}_{3} \mathrm{Si}_{3} \mathrm{CAlF}_{2}(\mu\right.\right.$-O)$\left.\mathrm{F}_{2} \mathrm{AlC}\left(\mathrm{SiMe}_{3}\right)_{3}\right]$ species in $\mathbf{1 0}$ is comparable to the $\left[\left(\mathrm{Me}_{3} \mathrm{Si}_{3} \mathrm{CAlF}_{2}(\mu-\mathrm{F}) \mathrm{F}_{2} \mathrm{AlC}\left(\mathrm{SiMe}_{3}\right)_{3}\right]\right.$ unit in $\left[\left\{\left(\mathrm{Me}_{3} \mathrm{Si}\right)_{3} \mathrm{C}\right\}_{4} \mathrm{Al}_{4} \mathrm{~K}_{2}(\mu-\mathrm{F})_{2} \mathrm{~F}_{8}(\mathrm{THF})_{4}\right](2), \quad\left[\mathrm{Ag}(\text { toluene })_{3}\right]^{+}\left[\left\{\left(\left(\mathrm{Me}_{3} \mathrm{Si}\right)_{3} \mathrm{C}\right)_{2} \mathrm{Al}_{2}(\mu-\mathrm{F}) \mathrm{F}_{4}\right\}_{2} \mathrm{Li}^{-}\right.$ (3), $\left[\mathrm{AlF}_{2}(\mathrm{THF})_{4}\right]^{+}\left[\left\{\left(\mathrm{Me} \mathrm{Si}_{3} \mathrm{C}_{2} \mathrm{Al}_{2}(\mu-\mathrm{F}) \mathrm{F}_{4}\right]^{-}(\mathbf{4})\right.\right.$, and in $\left[\left\{\left(\mathrm{Me}_{3} \mathrm{Si}\right)_{3} \mathrm{C}\right\}_{2} \mathrm{Al}_{2}(\mu-\mathrm{F}) \mathrm{F}_{4} \mathrm{~K}\right]_{\infty}(\mathbf{1 2})$.

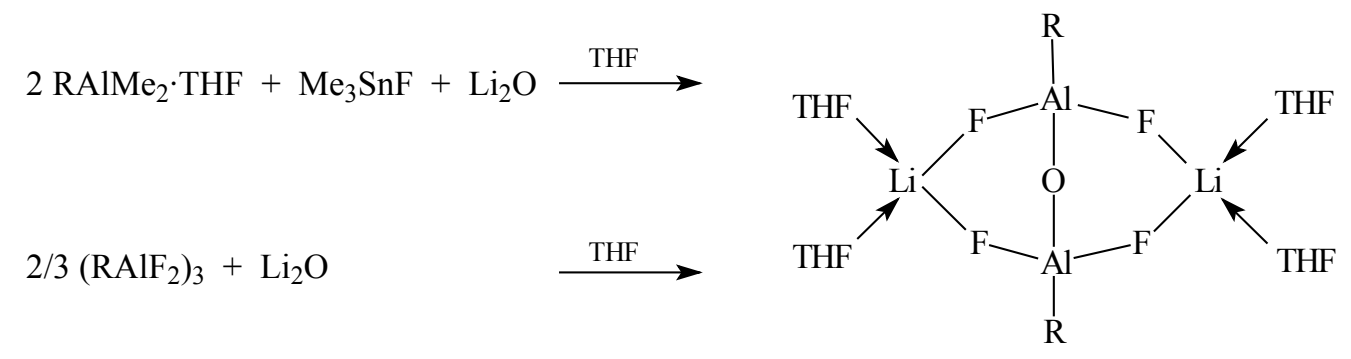


The $\left[\left(\mathrm{Me}_{3} \mathrm{Si}_{3}\right)_{3} \mathrm{CAlF}_{2}(\mu-\mathrm{O}) \mathrm{F}_{2} \mathrm{AlC}\left(\mathrm{SiMe}_{3}\right)_{3}\right]^{2-}$ species in formula $\mathbf{1 0}$ contains two negative charges in contrast to one negative charge in the $\left[\left(\mathrm{Me}_{3} \mathrm{Si}_{3} \mathrm{CAlF}_{2}(\mu-\mathrm{F}) \mathrm{F}_{2} \mathrm{AlC}\left(\mathrm{SiMe}_{3}\right)_{3}\right]^{-}\right.$part of the other bimetallic fluoro complexes.

The reaction of $\left(\mathrm{Me} \mathrm{Si}_{3}\right)_{3} \mathrm{CAlF}_{2} \cdot \mathrm{THF}$ with $\mathrm{LiOCH}\left(\mathrm{CF}_{3}\right)_{2}$ afforded the unexpected compound $\left[\left\{\mathrm{Li}\left(\mathrm{Me}_{3} \mathrm{Si}_{3}\right)_{3} \mathrm{CAlF}_{3}(\mathrm{THF})\right\}_{3} \mathrm{LiF}(\mathrm{THF})\right](\mathbf{1 1})$. Complex 11 illustrates the structural variety accessible by the combination of $\left[\left(\mathrm{Me}_{3} \mathrm{Si}\right)_{3} \mathrm{CAlF}_{2}\right]_{3}$ and $\mathrm{LiF}$. In the series of the alkali metals the lithium derivative $\mathbf{1 1}$ has a different structural arrangement compared to those of the analogous compounds of the heavier alkali metals.

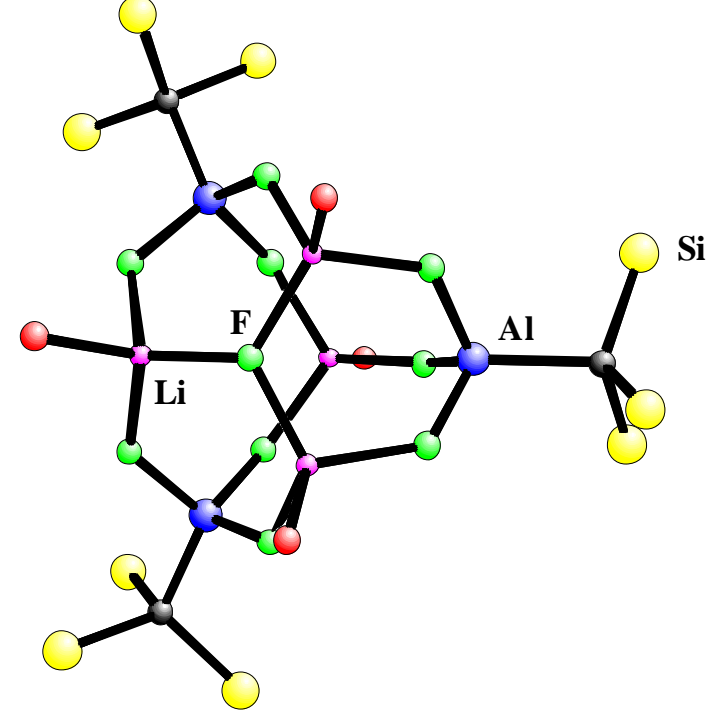

11

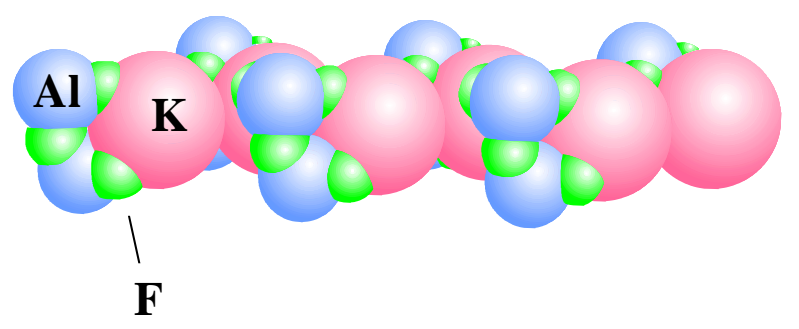

12

The supramolecular chain 12 was obtained by treating $\left[\left(\mathrm{Me}_{3} \mathrm{Si}\right)_{3} \mathrm{CAlF}_{2}\right]_{3}$ with potassium metal or potassium fluoride. The potassium in $\mathbf{1 2}$ has the coordination number four with a fifth fluorine atom in a weak contact. These investigations indicate the activation of the Al-F bond using KF in the absence of a coordinating solvent.

The new aluminum difluoride $\left(\mathrm{CycMe}_{2} \mathrm{Si}\right)\left(\mathrm{Me}_{3} \mathrm{Si}\right)_{2} \mathrm{CAlF}_{2} \cdot \mathrm{THF}(\mathbf{1 3})$ and an oxygen bounded aluminum fluoride of composition $\left(2,6-t \mathrm{Bu}_{2} \mathrm{C}_{6} \mathrm{H}_{3} \mathrm{O}\right)_{2} \mathrm{AlF} \cdot \mathrm{THF}(\mathbf{1 4})$ were prepared. 
The synthesis of $\left[n \mathrm{Bu}_{4} \mathrm{~N}\right]\left[\left(\mathrm{Me}_{3} \mathrm{Si}\right)_{3} \mathrm{CAlMeF}_{2}\right](\mathbf{1 5})$ is a straightforward route for a structurally characterized difluorodiorganoaluminate. The synthesis of this compound is accomplished through protonolysis of the methyl group with tetra-nbutylammonium hydrogen difluoride (TBADF), which induces elimination of methane and addition of two fluoride ions.
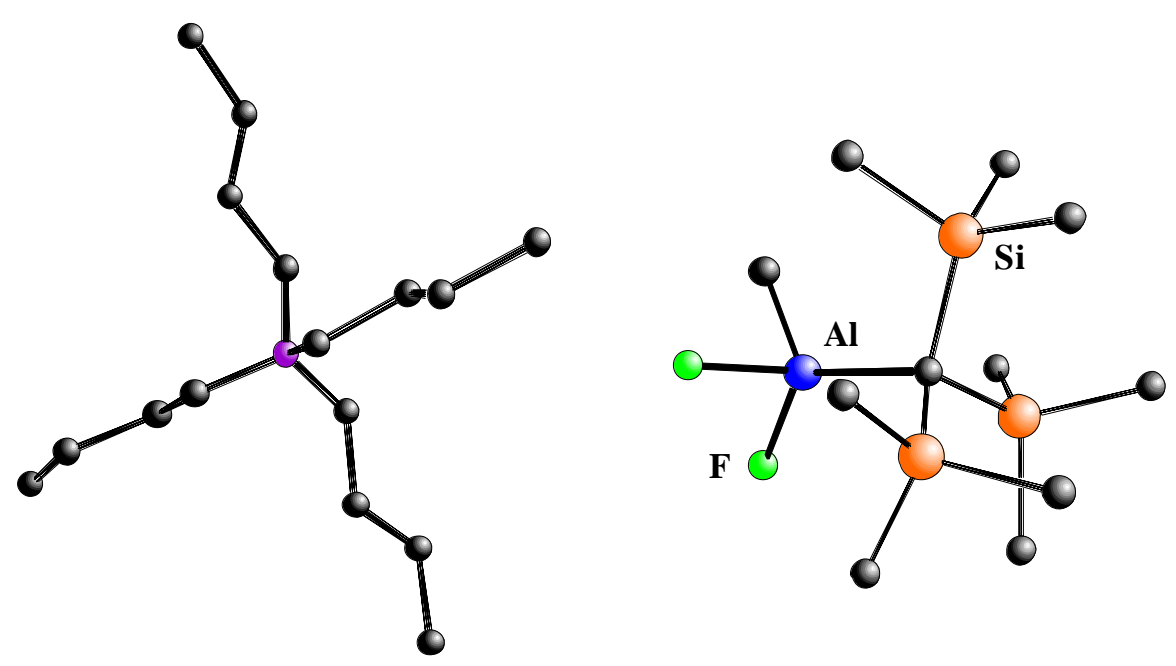

15

The reaction of $\left(\mathrm{Me}_{3} \mathrm{Si}\right)_{3} \mathrm{CAlMe} 2$ THF with $\mathrm{CF}_{3} \mathrm{COOH}$ in a $1: 3$ molar ratio afforded $\left[\mathrm{Al}_{3^{-}}\right.$ $\left.\left(\mu_{3}-\mathrm{O}\right)\left(\mu-\mathrm{O}_{2} \mathrm{CCF}_{3}\right)_{6}(\mathrm{THF})_{3}\right]^{+}\left[\left(\mathrm{Me}_{3} \mathrm{Si}\right)_{3} \mathrm{CAl}\left(\mathrm{OC}(\mathrm{O}) \mathrm{CF}_{3}\right)_{3}\right]^{-}$(18) which is the first X-ray structurally characterized oxo-centered trinuclear carboxylate complex of aluminum. The trinuclear aluminum cation of $\mathbf{1 8}$ exhibits high symmetry and offers the possibility for simplified computer studies.
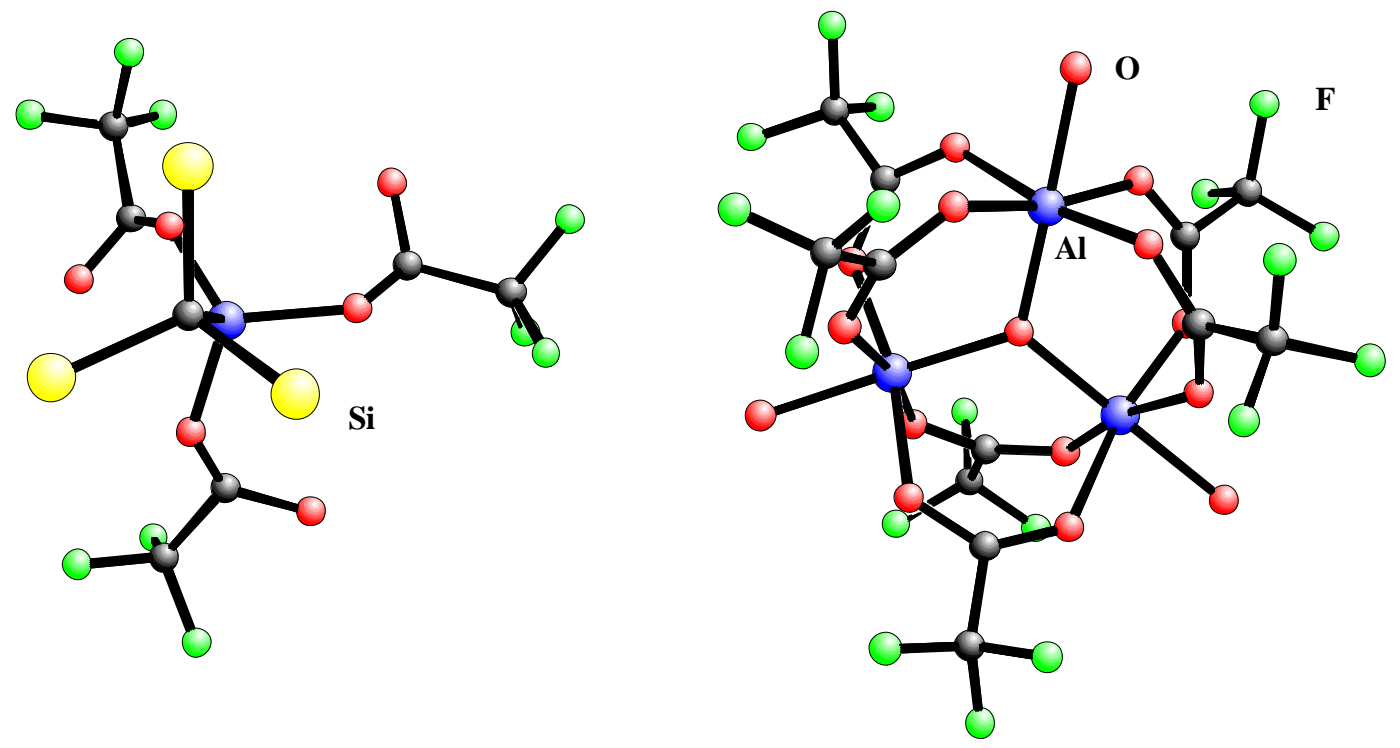


\subsection{Outlook}

The straighforward synthesis of $\left[\mathrm{Cp}_{2} \mathrm{ZrMe}\right](\mu-\mathrm{F})\left[\mathrm{F}_{2} \mathrm{AlC}\left(\mathrm{SiMe}_{3}\right)_{3}\right](\mathbf{7})$ may be applied to more bulky metallocenes. It can be seen that $\left[\mathrm{Cp}_{2} \mathrm{ZrMe}\right](\mu-\mathrm{F})\left[\mathrm{Al}\left(\mathrm{C}_{12} \mathrm{~F}_{9}\right)_{3}\right]$ exhibits negligible ethene polymerization activity. Increasing the bulkyness of the ancillary ligand ( $\mathrm{Cp}^{*}$ instead of $\mathrm{Cp}$ ) results in a drastic increase of polymerization activity in $\left[\mathrm{Cp}^{*}{ }_{2} \mathrm{ZrMe}\right](\mu-\mathrm{F})\left[\mathrm{Al}\left(\mathrm{C}_{12} \mathrm{~F}_{9}\right)_{3}\right][52]$.

Further investigations have to prove if the identified $\left[\left(\mathrm{Me}_{3} \mathrm{Si}\right)_{3} \mathrm{CAlF}_{2}(\mu-\mathrm{O}) \mathrm{F}_{2} \mathrm{AlC}\left(\mathrm{SiMe}_{3}\right)_{3}\right]$ species in $\mathbf{1 0}$ is useful for new bimetallic fluorine oxygen clusters. Probably it is possible to generate weakly coordinating anions according to the developed principle in $\left.[\mathrm{Ag} \text { (toluene })_{3}\right]^{+}\left[\left\{\left(\left(\mathrm{Me}_{3} \mathrm{Si}\right)_{3} \mathrm{C}\right)_{2} \mathrm{Al}_{2}(\mu-\mathrm{F}) \mathrm{F}_{4}\right\}_{2} \mathrm{Li}\right]^{-}(3)$. Using the $\left[\left(\mathrm{Me}_{3} \mathrm{Si}\right)_{3} \mathrm{CAlF}_{2}(\mu-\mathrm{O}) \mathrm{F}_{2} \mathrm{Al}-\right.$ $\left.\mathrm{C}\left(\mathrm{SiMe}_{3}\right)_{3}\right]$ species similar to the established $\left[\left(\mathrm{Me}_{3} \mathrm{Si}\right)_{3} \mathrm{CAlF}_{2}(\mu-\mathrm{F}) \mathrm{F}_{2} \mathrm{AlC}\left(\mathrm{SiMe}_{3}\right)_{3}\right]$ species in 3 would lead to a threefold charged anion. A threefold charged weak/non coordinating anion would be a great improvement in the research field of "weakly coordinating anions" [49].

An organoaluminum difluoride containing an alkali metal cation without coordinating solvents as in $\left[\left\{\left(\mathrm{Me}_{3} \mathrm{Si}\right)_{3} \mathrm{C}\right\}_{2} \mathrm{Al}_{2}(\mu-\mathrm{F}) \mathrm{F}_{4} \mathrm{~K}\right]_{\infty}(\mathbf{1 2})$ is synthesized and offers new possibilities to generate weakly coordinating anions and to study the activation of aluminum fluorine bonds.

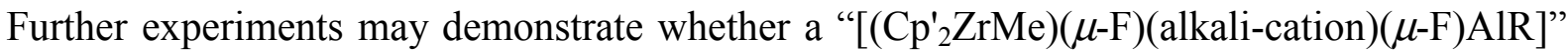
(substituting THF in $\mathbf{5 , 9}-\mathbf{1 2}$ by $\mathrm{Cp}_{2}^{\prime} \mathrm{ZrMe}^{+}$) species is a valid approach to alternatives for Ziegler-Natta catalysts.

The oxo-centered trinuclear carboxylate cation in $\left[\mathrm{Al}_{3}\left(\mu_{3}-\mathrm{O}\right)\left(\mu-\mathrm{O}_{2} \mathrm{CCF}_{3}\right)_{6}(\mathrm{THF})_{3}\right]^{+}$ $\left[\left(\mathrm{Me}_{3} \mathrm{Si}\right)_{3} \mathrm{CAl}\left(\mathrm{O}_{2} \mathrm{CCF}_{3}\right)_{3}\right]^{-}(\mathbf{1 8})$ is of high symmetry. 18 is a model compound for the bonding situation in the class of oxo-centered trinuclear carboxylates. $\mathbf{1 8}$ allows simplified computional analysis of this type of compounds without complications by unpaired electrons as in transition metals. The electron density calculations are already in progress and will hopefully provide reliable results $[95,96]$. 


\section{Experimental Section}

\subsection{General Procedures}

All experiments, unless stated otherwise, were performed using standard Schlenk techniques [100] under a dry nitrogen atmosphere due to the sensitive behavior of the reactants and products toward air and moisture. A Braun MB 150-GI Box was used to store the compounds and to prepare the samples for spectroscopic characterization. The $\mathrm{O}_{2}$ and $\mathrm{H}_{2} \mathrm{O}$ levels were normally kept below 5 ppm and 1 ppm, respectively. Commercial grade solvents were purified and freshly distilled from sodium/benzophenone and degassed prior to use [101].

\subsection{Physical Measurements}

Melting points were measured in sealed glass capillaries on a Büchi 540 instrument.

Elemental analyses were performed by the Analytical Laboratory of the Institute of Inorganic Chemistry, University of Göttingen.

NMR spectra were recorded on Bruker AM 200, Bruker Avance 200, Bruker AM 250, Bruker AS 400, and Bruker Avance 500 instruments. Chemical shifts were referenced to external standards, namely $\mathrm{SiMe}_{4}$ for ${ }^{1} \mathrm{H}$ and ${ }^{29} \mathrm{Si}, \mathrm{LiCl}$ for ${ }^{7} \mathrm{Li}$, and $\mathrm{CFCl}_{3}$ for ${ }^{19} \mathrm{~F}$. The chemical shifts referenced to $\mathrm{C}_{6} \mathrm{~F}_{6}$ are converted to the $\mathrm{CFCl}_{3}$ values $\left(\delta\left(\mathrm{CFCl}_{3}\right)-\delta\left(\mathrm{C}_{6} \mathrm{~F}_{6}\right)=-162.28 \mathrm{ppm}\right)$. All heteroatom NMR spectra were measured ${ }^{1} \mathrm{H}$ decoupled. Downfield shifts from the reference are quoted as positive and the upfield shifts as negative values. The solvents for NMR measurements were dried over sodium and distilled prior to use. The multiplicities of the signals are assigned as: $\mathrm{s}=$ singlet, $\mathrm{d}=$ doublet, $\mathrm{t}=$ triplet, $\mathrm{m}=$ multiplet. 
Mass spectra were obtained on Finnigan MAT 8230 and Varian MAT CH 5 instruments by EI- and FAB-MS techniques. Only the strongest peak of any isotopic distribution is given.

Infrared spectra were recorded on a Bio Rad FTS-7 spectrometer as nujol mulls between $\mathrm{KBr}$ plates, as $\mathrm{KBr}$ pellets, or as CsI pellets. Only relevant absorptions are reported. The absorption intensities are assigned as: vs = very strong, $\mathrm{s}=$ strong, $\mathrm{m}=$ medium.

X-ray structure determinations: Suitable crystals were mounted on glass fibers in a rapidly cooled perfluoropolyether [102]. Data for the $2: 1$ mixture of compounds $\mathbf{7}$ and $\mathbf{8 , 1 2}, \mathbf{1 5}$, and 18 were collected on a Stoe four circle diffractometer, for compound $\mathbf{8}$ on a Bruker AXS SMART CCD System, for compound $\mathbf{9}$ and $\mathbf{1 0}$ on a Stoe-Siemens-Huber four circle diffractometer with a Siemens SMART CCD area detector and for compound $\mathbf{1 1}$ on a Stoe IPDS II System. Mo-K $\alpha$ radiation $(\lambda=0.71073 \AA)$ was used in all cases, performing $\phi$ - and $\omega$-scans. Data reduction and space group determination routines were carried out using Siemens SHELXTL programs [103]. The structures were solved by direct methods employing SHELXTL-93/96/97 programs. The structure refinements were carried out by full-matrix least-squares methods against $F^{2}$ using SHELXTL-93/96/97 [104]. All non-hydrogen atoms were refined anisotropically. All hydrogen atoms were included in the model at geometrically calculated positions and refined using a riding model. The crystal data for compounds 7 - 12, $\mathbf{1 5}$ and $\mathbf{1 8}$ along with structure factors and refinement parameters are tabulated in Section 6.

\subsection{Starting Materials}

$\mathrm{Cp}_{2} \mathrm{ZrMe}_{2}$ [105], $\left(\mathrm{Me}_{3} \mathrm{Si}\right)_{3} \mathrm{CAlMe}{ }_{2} \cdot \mathrm{THF}$ [65], $\mathrm{Me}_{3} \mathrm{SnF}$ [106], $\left(\mathrm{CycMe}_{2} \mathrm{Si}\right)\left(\mathrm{Me}_{3} \mathrm{Si}\right)_{2} \mathrm{C}-$ $\mathrm{AlMe}_{2} \cdot \mathrm{THF} \quad$ [76], DDPAlMe ${ }_{2} \quad$ [75], $\quad\left(2,6-t \mathrm{Bu}_{2} \mathrm{C}_{6} \mathrm{H}_{3} \mathrm{O}\right) \mathrm{AlMe}_{2} \cdot \mathrm{THF} \quad$ [107], and (2,6- $\left.t \mathrm{Bu}_{2} \mathrm{C}_{6} \mathrm{H}_{3} \mathrm{O}\right)_{2} \mathrm{AlMe}$ [77] were prepared according to literature procedures. $\mathrm{K}, \mathrm{KF}, \mathrm{NaCl}$, $\mathrm{NaF}, \mathrm{MeLi}$, and $\left(\mathrm{CF}_{3}\right)_{2} \mathrm{CHOH}$ were purchased from Aldrich, Acros, or Fluka. (Preparation of the reagents: $\mathrm{K}$ was washed with $n$ hexane. $\mathrm{NaCl}, \mathrm{NaF}$, and $\mathrm{KF}$ were heated at $250{ }^{\circ} \mathrm{C}$ to 
remove moisture in vacuo. $n \mathrm{Bu}_{4} \mathrm{NHF}_{2}$ (Fluka) was received as a $50 \%$ solution in dichloromethane. The dichloromethane was removed in vacuo and the $n \mathrm{Bu}_{4} \mathrm{NHF}_{2}$ was dissolved in THF.)

\subsection{Improved Synthesis of $\left[\left(\mathrm{Me}_{3} \mathrm{Si}\right)_{3} \mathrm{CAIF}_{2}\right]_{3}(1)[43,109]$}

A mixture of $\left(\mathrm{Me}_{3} \mathrm{Si}\right)_{3} \mathrm{CAlMe}_{2}$.THF (3.61 g, $\left.10.0 \mathrm{mmol}\right)$ and $\mathrm{Me}_{3} \mathrm{SnF}(3.66 \mathrm{~g}, 20.0 \mathrm{mmol})$ in THF $(30 \mathrm{~mL})$ was stirred for $12 \mathrm{~h}$. After the THF had been pumped off the residue was heated for $4 \mathrm{~h}$ at $150{ }^{\circ} \mathrm{C}$ in vacuo. Pale yellow 1 (2.95 g, $\left.9.95 \mathrm{mmol}, 99 \%\right)$ remained.

${ }^{1} \mathrm{H}$ NMR (200 MHz, $\left.\mathrm{C}_{6} \mathrm{D}_{6}, \mathrm{ppm}\right): \delta 0.38(\mathrm{~s})$.

${ }^{19} \mathrm{~F}$ NMR (188 MHz, $\mathrm{C}_{6} \mathrm{D}_{6}$, ppm, external standard $\left.\mathrm{CFCl}_{3}\right): \delta$-149.6 (s).

For more data see ref. [43].

\subsection{Synthesis of $\left[\mathrm{Cp}_{2} \mathrm{ZrMe}\right](\mu-\mathrm{F})\left[\mathrm{F}_{2} \mathrm{AlC}\left(\mathrm{SiMe}_{3}\right)_{3}\right] \quad$ (7) and $\left[\mathrm{Cp}_{2} \mathrm{Zr}(\mu-\mathrm{F})_{2}-\right.$ $\left.\operatorname{FAIC}\left(\mathrm{SiMe}_{3}\right)_{3}\right]_{2} \mathrm{O}(8)$}

Preparation of 7. A mixture of $\mathrm{Me}_{3} \mathrm{SnF}(0.464 \mathrm{~g}, 2.54 \mathrm{mmol}), 1$ (0.750 g, $\left.0.84 \mathrm{mmol}, 1 / 3 \mathrm{eq}\right)$ and $\mathrm{Cp}_{2} \mathrm{ZrMe}_{2}(0.640 \mathrm{~g}, 2.54 \mathrm{mmol})$ in toluene $(40 \mathrm{~mL})$ was stirred for $24 \mathrm{~h}$ at $0{ }^{\circ} \mathrm{C}$. The solution was then allowed to warm to room temperature and stirred for another 3 days. After filtration the solid was recrystallized from toluene/nhexane $(4: 1)$ at $-20{ }^{\circ} \mathrm{C}$. 7 was obtained as a colorless solid $(0.900 \mathrm{~g}, 1.63 \mathrm{mmol}, 64 \%)$ that decomposes slowly at $200{ }^{\circ} \mathrm{C}$.

Anal. Calcd for $\mathrm{C}_{21} \mathrm{H}_{40} \mathrm{AlF}_{3} \mathrm{Si}_{3} \mathrm{Zr}$ (552.01): C, 45.69; H, 7.30. Found: C, 44.6; H, 6.9.

${ }^{1} \mathrm{H}$ NMR (250 MHz, $\left.\mathrm{C}_{6} \mathrm{D}_{6}, \mathrm{ppm}\right): \delta 0.48$ (s, $\left.27 \mathrm{H}, \mathrm{SiCH}_{3}\right), 0.56$ (s, $\left.3 \mathrm{H}, \mathrm{ZrCH}_{3}\right), 6.36$ (s, 10 $\left.\mathrm{H}, \mathrm{C}_{5} H_{5}\right)$; 
${ }^{19} \mathrm{~F}$ NMR (235 MHz, $\mathrm{C}_{6} \mathrm{D}_{6}$, ppm, external standard $\left.\mathrm{CFCl}_{3}\right): \delta-165.4\left(\mathrm{~s}, 2 \mathrm{H}, \mathrm{Al} F_{2}\right),-161.8$ (s, $1 \mathrm{H}, \mathrm{Al}(\mu-F) \mathrm{Zr})$.

IR (KBr, Nujol, cm $\left.{ }^{-1}\right): 1251$ s, 1016 s, 863 s, 797 m, 770 s, 680 m, 615 m, 546 m.

Preparation of $8.7(0.200 \mathrm{~g}, 0.36 \mathrm{mmol})$ was dissolved in THF/toluene/nhexane $(1: 8: 2)$. Crystallization at $-20{ }^{\circ} \mathrm{C}$ afforded $\mathbf{8}(0.010 \mathrm{~g}, 0.01 \mathrm{mmol})$ after four weeks as a colorless solid. $\mathbf{8}$ was only characterized by single crystal X-ray structure analysis.

Preparation of a crystalline $2: 1$ mixture of compounds 7 and 8. Dissolving 7 (0.200 g, $0.36 \mathrm{mmol})$ in a mixture of $\mathrm{THF} /$ toluene/nhexane $(1: 8: 2)$ and cooling the solution at $-20{ }^{\circ} \mathrm{C}$ for 4 weeks resulted in the formation of a mixture of crystals of composition of $\mathbf{7}$ and $\mathbf{8}$. Only the crystals formed were used for the characterization of this mixture.

\subsection{Synthesis of $\left[\mathrm{Na}\left(\mathrm{Me}_{3} \mathrm{Si}\right)_{3} \mathrm{CAlF}_{3}(\mathrm{THF})\right]_{4}(9)$}

A mixture of trimethyltin fluoride $(2.19 \mathrm{~g}, 12.0 \mathrm{mmol}), \mathrm{NaCl}(0.470 \mathrm{~g}, 8.00 \mathrm{mmol})$ and $\left(\mathrm{Me}_{3} \mathrm{Si}\right)_{3} \mathrm{CAlMe}_{2}(\mathrm{THF})(0.721 \mathrm{~g}, 2.00 \mathrm{mmol})$ in THF $(20 \mathrm{~mL})$ was stirred for 4 days. The solvent was evaporated in vacuo. The residue was washed with pentane $(5 \mathrm{~mL})$ and afterwards extracted with toluene $(40 \mathrm{~mL})$. All solvents were removed under reduced pressure. $9(0.329 \mathrm{~g}, 0.20 \mathrm{mmol}, 40 \%)$ was obtained as a colorless solid, which can be heated to $300{ }^{\circ} \mathrm{C}$ without decomposition or melting.

Anal. Calcd for $\mathrm{C}_{56} \mathrm{H}_{140} \mathrm{Al}_{4} \mathrm{~F}_{12} \mathrm{Na}_{4} \mathrm{O}_{4} \mathrm{Si}_{12}$ (1642.62): C, 40.95; H, 8.59. Found: C, 40.0; H, 8.3. ${ }^{1} \mathrm{H}$ NMR (250 MHz, $\left.\mathrm{C}_{6} \mathrm{D}_{6}, \mathrm{ppm}\right): \delta 0.41\left(\mathrm{~s}, 27 \mathrm{H}, \mathrm{SiCH}_{3}\right), 1.45\left(\mathrm{~m}, 4 \mathrm{H}, \mathrm{OCH}_{2} \mathrm{CH}_{2}\right), 3.68(\mathrm{~m}$, $\left.4 \mathrm{H}, \mathrm{OCH}_{2} \mathrm{CH}_{2}\right)$.

${ }^{19}$ F NMR (235 MHz, $\mathrm{C}_{6} \mathrm{D}_{6}$, ppm, external standard $\left.\mathrm{CFCl}_{3}\right): \delta$-176.7 (s).

${ }^{29} \mathrm{Si}$ NMR (50 MHz, $\left.\mathrm{C}_{6} \mathrm{D}_{6}, \mathrm{ppm}\right): \delta-3.5$ (s).

IR (KBr, Nujol, cm $\left.{ }^{-1}\right): 1260$ s, 863 m, 726 m, 671 m. 


\subsection{Synthesis of $\left[\left\{\left(\mathrm{Me}_{3} \mathrm{Si}\right)_{3} \mathrm{CAIF}_{2}\right\}_{2}(\mu-\mathrm{O}) \mathrm{Li}_{2}(\mathrm{THF})_{4}\right](10)$}

First method: A mixture of $\mathbf{1}(0.589 \mathrm{~g}, 0.66 \mathrm{mmol})$ and $\mathrm{Li}_{2} \mathrm{O}(0.030 \mathrm{~g}, 1.00 \mathrm{mmol})$ in THF (20 $\mathrm{mL}$ ) was stirred for 2 days. The mixture was filtered. Crystallization at $-20{ }^{\circ} \mathrm{C}$ resulted in a colorless crystalline solid $10(0.619 \mathrm{~g}, 0.68 \mathrm{mmol}, 68 \%)$, mp $178-179{ }^{\circ} \mathrm{C}$.

Second method: A mixture of $\left(\mathrm{Me}_{3} \mathrm{Si}\right)_{3} \mathrm{CAlMe}_{2}$ THF (0.722 g, $\left.2.00 \mathrm{mmol}\right), \mathrm{Me}_{3} \mathrm{SnF}$ (0.732 g, $4.00 \mathrm{mmol})$ and $\mathrm{Li}_{2} \mathrm{O}(0.030 \mathrm{~g}, 1.00 \mathrm{mmol})$ in THF $(20 \mathrm{~mL})$ was heated at reflux for $6 \mathrm{~h}$. All solvents were removed in vacuo. The residue was dissolved in THF $(20 \mathrm{~mL})$ and filtered. Crystallization at $-20{ }^{\circ} \mathrm{C}$ afforded $\mathbf{1 0}(0.735 \mathrm{~g}, 0.81 \mathrm{mmol}, 81 \%)$ as a colorless crystalline solid, mp $177-179^{\circ} \mathrm{C}$.

Anal. Calcd for $\mathrm{C}_{36} \mathrm{H}_{86} \mathrm{Al}_{2} \mathrm{~F}_{4} \mathrm{Li}_{2} \mathrm{O}_{5} \mathrm{Si}_{6}$ (911.43): C, 47.44; H, 9.51. Found: C, 46.8; H, 9.4.

${ }^{1} \mathrm{H}$ NMR (200 MHz, $\left.\mathrm{C}_{6} \mathrm{D}_{6}, \mathrm{ppm}\right): \delta 0.43\left(\mathrm{~s}, 54 \mathrm{H}, \mathrm{SiCH}_{3}\right), 0.90\left(\mathrm{~m}, 16 \mathrm{H}, \mathrm{CH}_{2} \mathrm{CH}_{2} \mathrm{O}\right), 3.79$ (m, $\left.16 \mathrm{H}, \mathrm{CH}_{2} \mathrm{CH}_{2} \mathrm{O}\right)$.

${ }^{7} \mathrm{Li}$ NMR (97 MHz, $\left.\mathrm{C}_{6} \mathrm{D}_{6}, \mathrm{ppm}\right): \delta-0.8(\mathrm{~s})$.

${ }^{19} \mathrm{~F}$ NMR (188 MHz, $\mathrm{C}_{6} \mathrm{D}_{6}$, ppm, external standard $\left.\mathrm{C}_{6} \mathrm{~F}_{6}\right): \delta-158.5$ (s).

${ }^{29} \mathrm{Si}$ NMR (50 MHz, $\left.\mathrm{C}_{6} \mathrm{D}_{6}, \mathrm{ppm}\right): \delta-3.4(\mathrm{~s})$.

IR (KBr, cm $\left.{ }^{-1}\right): 2957$ vs, 2903 vs, 1262 s, 1098 s, 1047 s, 1020 s, 855 vs, 718 vs, 674 m.

\subsection{Synthesis of $\left[\left\{\mathrm{Li}\left(\mathrm{Me}_{3} \mathrm{Si}_{3}\right)_{3} \mathrm{CAIF}_{3}(\mathrm{THF})\right\}_{3} \mathrm{LiF}(\mathrm{THF})\right](11)$}

MeLi (3.75 mL, 1.6 $M$ in $\left.\mathrm{Et}_{2} \mathrm{O}, 6.0 \mathrm{mmol}\right)$ was added to $\left(\mathrm{CF}_{3}\right)_{2} \mathrm{CH}(\mathrm{OH})(1.01 \mathrm{~g}, 6.00 \mathrm{mmol})$ in THF (30 mL) and the mixture was stirred for $3 \mathrm{~h}$. This solution was added to $\mathbf{1}(1.79 \mathrm{~g}$, $2.00 \mathrm{mmol})$ in THF $(30 \mathrm{~mL})$ and the resulting mixture stirred for 3 days. All solvents were removed in vacuo. The residue was dissolved in toluene/THF $(30 \mathrm{~mL}, 20: 1)$ and filtered. Crystallization at $-20^{\circ} \mathrm{C}$ afforded $11(0.302 \mathrm{~g}, 0.22 \mathrm{mmol}, 11 \%)$ after 2 weeks as a colorless crystalline solid, $\mathrm{mp}>300{ }^{\circ} \mathrm{C}$. 
For the elemental analysis the crystals of composition $\mathbf{1 1}+$ THF were used. Anal. Calcd for $\mathrm{C}_{50} \mathrm{H}_{121} \mathrm{Al}_{3} \mathrm{~F}_{10} \mathrm{Li}_{4} \mathrm{O}_{5} \mathrm{Si}_{9}$ (1353.98): C, 44.35; H, 9.01. Found: C, 44.8; H, 9.0.

${ }^{1} \mathrm{H}$ NMR (200 MHz, THF-d $\left.8, \mathrm{ppm}\right): \delta 0.15\left(\mathrm{~s}, 81 \mathrm{H}, \mathrm{SiCH}_{3}\right), 1.77\left(\mathrm{~m}, 16 \mathrm{H}, \mathrm{CH}_{2} \mathrm{CH}_{2} \mathrm{O}\right), 3.61$ (m, $\left.16 \mathrm{H}, \mathrm{CH}_{2} \mathrm{CH}_{2} \mathrm{O}\right)$.

${ }^{7} \operatorname{Li}$ NMR (97 MHz, THF-d 8, ppm): $\delta-0.5(\mathrm{~s})$.

${ }^{19} \mathrm{~F}$ NMR (188 MHz, THF-d 8 , ppm, external standard $\mathrm{C}_{6} \mathrm{~F}_{6}$ ): at $\delta-166.5$ (s) the main resonance, with a very small resonance at -202.8 (s).

${ }^{29} \mathrm{Si}$ NMR (99 MHz, THF-d, ppm): $\delta-1.8(\mathrm{~s})$.

$\operatorname{MS}\left(\mathrm{FAB}_{(\mathrm{neg})}\right): m / z 1203(2 \%, M-\mathrm{Li}-\mathrm{THF}), 1057$ (100\%, $M$ - Li - 3 THF).

IR (KBr, cm $\left.{ }^{-1}\right): 2978$ vs, 2956 vs, 2900 vs, 1463 s, 1292 s, 1212 s, 1054 vs, 874 vs, 837 vs, $755 \mathrm{~s}, 724 \mathrm{~s}, 708 \mathrm{~s}, 674 \mathrm{vs}, 626 \mathrm{~s}$.

\subsection{Synthesis of $\left[\left\{\left(\mathrm{Me}_{3} \mathrm{Si}\right)_{3} \mathrm{C}\right\}_{2} \mathrm{Al}_{2}(\mu-\mathrm{F}) \mathrm{F}_{4} \mathrm{~K}\right]_{\infty}(12)$}

First method: 1 (1.04 g, $1.16 \mathrm{mmol})$ and KF (0.093 g, $1.60 \mathrm{mmol})$ in toluene $(20 \mathrm{~mL})$ were heated under reflux for $6 \mathrm{~h}$. After cooling the reaction mixture, the solvent was removed in vacuo. The residue was extracted with hot nhexane $(20 \mathrm{~mL})$ to remove excess $\mathbf{1}$. The solid was again treated with toluene $(20 \mathrm{~mL})$ and heated under reflux for $1 \mathrm{~h}$. Crystallization at ambient temperature resulted in $0.180 \mathrm{~g}$ of $\mathbf{1 2}(0.28 \mathrm{mmol}, 18 \%)$ as a colorless crystalline solid, $\mathrm{mp}>300{ }^{\circ} \mathrm{C}$.

Second method: 1 (0.892 g, $1.00 \mathrm{mmol})$ and K(metal) $(0.039 \mathrm{~g}, 1.00 \mathrm{mmol})$ in toluene (20 $\mathrm{mL}$ ) were heated under reflux for $6 \mathrm{~h}$. Crystallization at ambient temperature resulted in $0.150 \mathrm{~g}$ of $12(0.23 \mathrm{mmol}, 23 \%)$ as a colorless crystalline solid with $\mathrm{mp}>300{ }^{\circ} \mathrm{C}$. The colorless crystals were manually separated.

Anal. Calcd for $\mathrm{C}_{20} \mathrm{H}_{54} \mathrm{Al}_{2} \mathrm{~F}_{5} \mathrm{KSi}_{6}$ (651.22): C, 36.89; H, 8.36. Found: C, 37.1; H, 8.4.

${ }^{1} \mathrm{H}$ NMR (200 MHz, $\left.\mathrm{C}_{6} \mathrm{D}_{6}, \mathrm{ppm}\right): \delta 0.42$ (s). 
${ }^{19} \mathrm{~F}$ NMR (188 MHz, $\mathrm{C}_{6} \mathrm{D}_{6}$, ppm, external standard $\left.\mathrm{C}_{6} \mathrm{~F}_{6}\right): \delta$-157.5 (s, $\left.4 \mathrm{~F}, \mathrm{Al}(\mu-F) \mathrm{K}\right),-157.3$ (s, $4 \mathrm{~F}, \mathrm{Al}(\mu-F) \mathrm{K}),-156.9$ (s, 1 F), -152.8 (m, $2 \mathrm{~F}, \mathrm{Al}(\mu-F) \mathrm{Al})$.

${ }^{29} \mathrm{Si}\left(99 \mathrm{MHz}, \mathrm{C}_{6} \mathrm{D}_{6}, \mathrm{ppm}\right):-3.4$ (s).

$\operatorname{MS}\left(\mathrm{FAB}_{(\mathrm{neg})}\right): m / z 669(40 \%, M+\mathrm{F}), 315\left(100 \%,\left[\left(\mathrm{Me}_{3} \mathrm{Si}_{3}\right)_{3} \mathrm{CAlF}_{3}\right]\right)$.

IR (CsI, cm $\left.{ }^{-1}\right): 2958$ s, 2904 s, 1202 vs, 1100 s, 1022 s, 857 vs, 688 s, 551 s, 406 s, 327 s.

\subsection{Synthesis of $\left(\mathrm{CycMe}_{2} \mathrm{Si}\right)\left(\mathrm{Me}_{3} \mathrm{Si}\right)_{2} \mathrm{CAIF}_{2} \cdot \mathrm{THF}(13)$}

A mixture of $\left(\mathrm{CycMe}_{2} \mathrm{Si}\right)\left(\mathrm{Me}_{3} \mathrm{Si}\right)_{2} \mathrm{CAlMe}_{2} \cdot \mathrm{THF}(2.00 \mathrm{~g}, 4.66 \mathrm{mmol})$ and $\mathrm{Me}_{3} \mathrm{SnF}(1.70 \mathrm{~g}$, $9.32 \mathrm{mmol})$ in THF $(20 \mathrm{~mL})$ was stirred for $12 \mathrm{~h}$ at room temperature. After removing all volatile components under vacuum the residue was dissolved in THF/nhexane $(30 \mathrm{~mL}, 1: 2)$. Crystallization at $-20{ }^{\circ} \mathrm{C}$ afforded the colorless compound $\mathbf{1 3}$ (1.44 g, 3.29 mmol, $\left.71 \%\right)$ $\left(\mathrm{mp} 108^{\circ} \mathrm{C}\right)$.

Anal. Calcd for $\mathrm{C}_{19} \mathrm{H}_{43} \mathrm{AlF}_{2} \mathrm{OSi}_{3}$ (436.78): C, 52.25; H, 9.92; Al, 6.18; F 8.70. Found: C, 51.5; H, 9.7; Al, 5.9; F 8.4.

${ }^{1} \mathrm{H}$ NMR (250 MHz, $\left.\mathrm{C}_{6} \mathrm{D}_{6}, \mathrm{ppm}\right): \delta 0.40$ (s, $\left.6 \mathrm{H}, \mathrm{SiCH}_{3}\right), 0.45$ (s, $\left.18 \mathrm{H}, \mathrm{SiCH}_{3}\right), 0.90(\mathrm{~m}, 4 \mathrm{H}$, $\mathrm{OCH}_{2} \mathrm{CH}_{2}$ ), 1.15 (m, $\left.1 \mathrm{H}, \mathrm{CH} \mathrm{C} 1-\mathrm{Cyc}\right), 1.35$ (m, $\left.2 \mathrm{H}, \mathrm{CH}_{2} \mathrm{C} 4-\mathrm{Cyc}\right), 1.80,2.15$ (m, 8 H, $\mathrm{CH}_{2}$ C2-Cyc, C3-Cyc), 3.80 (m, $\left.4 \mathrm{H}, \mathrm{OCH}_{2} \mathrm{CH}_{2}\right)$.

${ }^{19} \mathrm{~F}$ NMR (250 MHz, $\mathrm{C}_{6} \mathrm{D}_{6}$, ppm, external standard $\left.\mathrm{CFCl}_{3}\right): \delta-156.5$ (s).

${ }^{29} \mathrm{Si} \mathrm{NMR}\left(99 \mathrm{MHz}, \mathrm{C}_{6} \mathrm{D}_{6}, \mathrm{ppm}\right): \delta-3.2\left(\mathrm{SiMe}_{3}\right), 0.5\left(\mathrm{SiCycMe}_{2}\right)$.

MS (EI): $m / z 217\left(100 \%,\left(\mathrm{Me}_{3} \mathrm{Si}\right)_{2} \mathrm{CHSiMe}_{2}\right)$.

IR (KBr, cm $\left.{ }^{-1}\right): 2957$ s, 2920 s, 2849 m, 1448 m, 1254 s, 1097 m, 1045 m, 1011 m, 852 vs, $816 \mathrm{vs}, 718 \mathrm{~m}, 673 \mathrm{~s}, 616 \mathrm{~m}$. 


\subsection{Synthesis of $\left(2,6-t \mathrm{Bu}_{2} \mathrm{C}_{6} \mathrm{H}_{3} \mathrm{O}\right)_{2} \mathrm{AlF} \cdot \mathrm{THF}(14)$}

$\left(2,6-t \mathrm{Bu}_{2} \mathrm{C}_{6} \mathrm{H}_{3} \mathrm{O}\right)_{2} \mathrm{AlMe}(4.52 \mathrm{~g}, 10.0 \mathrm{mmol})$ and $\mathrm{Me}_{3} \mathrm{SnF}(1.82 \mathrm{~g}, 10.0 \mathrm{mmol})$ in THF (40 $\mathrm{mL}$ ) were stirred for $24 \mathrm{~h}$. All volatiles were evaporated and the residue extracted with toluene. Crystallization from THF at $-20{ }^{\circ} \mathrm{C}$ resulted $14(4.32 \mathrm{~g}, 8.17 \mathrm{mmol}, 82 \%)$ as a colorless solid (mp $\left.135-136^{\circ} \mathrm{C}\right)$.

Anal. Calcd for $\mathrm{C}_{32} \mathrm{H}_{50} \mathrm{AlFO}_{3}$ (528.73): C, 72.69; H, 9.53. Found: C, 72.2; H, 9.5.

${ }^{1} \mathrm{H}$ NMR (200 MHz, $\left.\mathrm{C}_{6} \mathrm{D}_{6}, \mathrm{ppm}\right): \delta 0.98\left(\mathrm{~m}, 4 \mathrm{H}, \mathrm{CH}_{2} \mathrm{CH}_{2} \mathrm{O}\right), 1.62\left(\mathrm{~s}, 18 \mathrm{H}, \mathrm{C}\left(\mathrm{CH}_{3}\right)_{3}\right), 3.58$ (m, $\left.4 \mathrm{H}, \mathrm{CH}_{2} \mathrm{CH}_{2} \mathrm{O}\right), 6.87$ (t, $\left.J=3 \mathrm{~Hz}, 1 \mathrm{H}, 4-\mathrm{Ph} H\right), 7.36(\mathrm{~d}, J=3 \mathrm{~Hz}, 2 \mathrm{H}, 3,5-\mathrm{Ph} H)$.

${ }^{19} \mathrm{~F}$ NMR (188 MHz, $\mathrm{C}_{6} \mathrm{D}_{6}, \mathrm{ppm}$, external standard $\left.\mathrm{C}_{6} \mathrm{~F}_{6}\right): \delta-161.8$ (s).

MS (EI): $m / z 528(20 \%, M), 456(60 \%, M-\mathrm{THF}), 42\left(100 \%, \mathrm{C}\left(\mathrm{CH}_{3}\right)_{2}\right)$.

IR (KBr, Nujol, cm'): 1262 s, 1101 m, 1021 m, 928 m, 756 m, 723 m, 626 m.

\subsection{Synthesis of $\left[n \mathrm{Bu}_{4} \mathrm{~N}\right]\left[\left(\mathrm{Me}_{3} \mathrm{Si}\right)_{3} \mathrm{CAIMeF}_{2}\right](15)$}

A solution of $\left(\mathrm{Me}_{3} \mathrm{Si}\right)_{3} \mathrm{CAlMe} 2 \cdot \mathrm{THF}(3.00 \mathrm{~g}, 8.32 \mathrm{mmol})$ in THF was added dropwise to a solution of TBADF (2.34 $\mathrm{g}, 8.32 \mathrm{mmol})$ in THF $(40 \mathrm{~mL})$ at room temperature, and the mixture was stirred for $12 \mathrm{~h}$. The solvent was removed in vacuo. The residue was redissolved in toluene $(30 \mathrm{~mL})$ and filtered. Crystallization at $0{ }^{\circ} \mathrm{C}$ for 3 days yielded $4.20 \mathrm{~g}(7.00 \mathrm{mmol}$, $84 \%$ ) of $\mathbf{1 5}$ as rhombic crystals (mp $\left.108^{\circ} \mathrm{C}\right)$.

For the elemental analysis crystals of composition $15+0.5$ molecule of $\mathrm{C}_{7} \mathrm{H}_{8}$ were used. Anal. Calcd for $\mathrm{C}_{30.5} \mathrm{H}_{70} \mathrm{AlF}_{2} \mathrm{NSi}_{3}$ (600.13): C, 61.0; H, 11.8; Al, 4.5; F, 6.3; N, 2.3. Found: $\mathrm{C}$, 61.8; H, 11.5; Al, 3.4; F, 5.5; N, 2.8.

${ }^{1} \mathrm{H}$ NMR $\left(200 \mathrm{MHz}, \mathrm{C}_{6} \mathrm{D}_{6}, \mathrm{ppm}\right): \delta-0.29\left(\mathrm{t}, J=2.8 \mathrm{~Hz}, 3 \mathrm{H}, \mathrm{AlCH}_{3}\right), 0.69\left(\mathrm{~s}, 27 \mathrm{H}, \mathrm{SiCH}_{3}\right)$, $0.91\left(\mathrm{t},{ }^{2} J_{\mathrm{HH}}=6.5 \mathrm{~Hz}, 12 \mathrm{H}, \mathrm{CH}_{3}\right), 1.12-1.31\left(\mathrm{~m}, 16 \mathrm{H}, \mathrm{CH}_{2} \mathrm{C} 2-\mathrm{Bu}, \mathrm{C} 3-\mathrm{Bu}\right), 2.91(\mathrm{~m}, 8 \mathrm{H}$, $\left.\mathrm{CH}_{2} \mathrm{C} 1-\mathrm{Bu}\right)$. 
${ }^{19} \mathrm{~F}$ NMR (235 MHz, $\mathrm{C}_{6} \mathrm{D}_{6}$, ppm, external standard $\left.\mathrm{CFCl}_{3}\right): \delta$-145.9 (s).

${ }^{29} \mathrm{Si}$ NMR (79 MHz, $\left.\mathrm{C}_{6} \mathrm{D}_{6}, \mathrm{ppm}\right): \delta-3.71(\mathrm{~s})$.

MS (EI): $m / z, 242\left(100 \%, \mathrm{Bu}_{4} \mathrm{~N}\right), 100\left(4 \%, \mathrm{Bu}(\mathrm{Me}) \mathrm{NCH}_{2}\right)$.

$\mathrm{MS}\left(\mathrm{FAB}_{(\text {neg) }}\right): m / z 311\left(100 \%,\left(\mathrm{Me}_{3} \mathrm{Si}\right)_{3} \mathrm{C}(\mathrm{Me}) \mathrm{AlF}_{2}\right)$.

IR (KBr, cm $\left.{ }^{-1}\right): 2965$ st, 2898 st, 2878 m, 1488 m, 1466 m, 1382m, 1243 s, 1179 m, 1029 m, 869 st, 787 m, 754 m, 741 m, 709 m, 680 m, 664 m, 640 m, 575 m.

\subsection{Reaction of $\left(\mathrm{Me}_{3} \mathrm{Si}\right)_{3} \mathrm{CAIMe} \cdot \mathrm{THF}$ with $\mathrm{CF}_{3} \mathrm{COOH}$ in a $1: 1$ molar ratio. Synthesis of $\left[\left(\mathrm{Me}_{3} \mathrm{Si}\right)_{3} \mathrm{CAIMe}\left(\mathrm{O}_{2} \mathrm{CCF}_{3}\right)\right]_{2}(16)$}

$\mathrm{CF}_{3} \mathrm{COOH}(0.335 \mathrm{~g}, 2.94 \mathrm{mmol}, 1 \mathrm{eq})$ was added to a solution of $\left(\mathrm{Me}_{3} \mathrm{Si}\right)_{3} \mathrm{CAlMe}_{2} \cdot \mathrm{THF}(1.06$ g, $2.94 \mathrm{mmol})$ in toluene $(20 \mathrm{~mL})$. The cloudy liquid was stirred for 1 day. An insoluble residue was filtered off and crystallized at $-20^{\circ} \mathrm{C}$ in THF. Small amounts of adherent solvent were removed in vacuo. 16 (0.419 g, $0.54 \mathrm{mmol}, 37 \%)$ was obtained as a colorless solid (decomposing at $210^{\circ} \mathrm{C}$ ).

Anal. Calcd for $\mathrm{C}_{26} \mathrm{H}_{60} \mathrm{Al}_{2} \mathrm{~F}_{6} \mathrm{O}_{4} \mathrm{Si}_{6}$ (773.23): C, 40.39; H, 7.82. Found: C, 41.1; H, 7.8.

${ }^{1} \mathrm{H}$ NMR (200 MHz, THF-d $\left.8, \mathrm{ppm}\right): \delta-0.47$ (s, $\left.3 \mathrm{H}, \mathrm{AlCH}_{3}\right), 0.23\left(\mathrm{~s}, 27 \mathrm{H}, \mathrm{SiCH}_{3}\right)$.

${ }^{19} \mathrm{~F}$ NMR (188 MHz, THF-d 8 , ppm, external standard $\left.\mathrm{C}_{6} \mathrm{~F}_{6}\right): \delta$-74.7 (s).

${ }^{29} \mathrm{Si}$ NMR (99 MHz, THF-d $\left.8, \mathrm{ppm}\right): \delta-4.1(\mathrm{~s})$.

MS (EI): $m / z 757(30 \%, M-\mathrm{Me}), 371(100 \%, M / 2$ - Me).

IR (KBr, Nujol, cm ${ }^{-1}$ ): 1732 m, 1699 s, 1207 m, 1170 m, 1077 m, 857 vs, 722 vs, 672 m. 


\subsection{Reaction of $\left(\mathrm{Me}_{3} \mathrm{Si}\right)_{3} \mathrm{CAIMe}{ }_{2} \cdot \mathrm{THF}$ with $\mathrm{CF}_{3} \mathrm{COOH}$ in a $1: 2$ molar ratio. Synthesis of $\left[\left(\mathrm{Me}_{3} \mathrm{Si}\right)_{3} \mathrm{CAl}\left(\mathrm{O}_{2} \mathrm{CCF}_{3}\right)_{2}\right]_{2}(17)$}

$\mathrm{CF}_{3} \mathrm{COOH}(0.860 \mathrm{~g}, 7.54 \mathrm{mmol}, 2 \mathrm{eq})$ was added to a solution of $\left(\mathrm{Me}_{3} \mathrm{Si}\right)_{3} \mathrm{CAlMe}{ }_{2} \cdot \mathrm{THF}(1.36$ g, $3.77 \mathrm{mmol})$ in toluene $(20 \mathrm{~mL})$ and stirred for 1 day. All solvents were removed in vacuo. The remaining solid was treated with $n$ hexane $(20 \mathrm{~mL})$ and filtered. Crystallization in toluene at $-20{ }^{\circ} \mathrm{C}$ afforded $17(1.66 \mathrm{~g}, 1.71 \mathrm{mmol}, 45 \%)$ as a colorless solid (decomposing at $\left.170{ }^{\circ} \mathrm{C}\right)$.

Anal. Calcd for $\mathrm{C}_{28} \mathrm{H}_{54} \mathrm{Al}_{2} \mathrm{~F}_{12} \mathrm{O}_{8} \mathrm{Si}_{6}$ (969.19): C, 34.70; H, 5.62. Found: C, 35.0; H, 5.7.

${ }^{1} \mathrm{H}$ NMR (200 MHz, THF-d 8 , ppm): $\delta 0.23$ (s).

${ }^{19} \mathrm{~F}$ NMR (188 MHz, THF-d 8 , ppm, external standard $\left.\mathrm{C}_{6} \mathrm{~F}_{6}\right): \delta-74.8$ (s).

${ }^{29} \mathrm{Si}$ NMR (99 MHz, THF-d $\left.8, \mathrm{ppm}\right): \delta-3.1(\mathrm{~s})$.

MS (EI): $m / z, 953(100 \%, M-\mathrm{Me})$.

IR (KBr, Nujol, cm ${ }^{-1}$ ): 1758 s, 1690 s, 1668 s, 1260 m, 1220 m, 1168 m, 857 vs, 724 m, 675 m.

\subsection{Reaction of $\left(\mathrm{Me}_{3} \mathrm{Si}\right)_{3} \mathrm{CAIMe}$. $\mathrm{THF}$ with $\mathrm{CF}_{3} \mathrm{COOH}$ in a $1: 3$ molar ratio. Synthesis of $\left[\mathrm{Al}_{3}\left(\mu_{3}-\mathrm{O}\right)\left(\mu-\mathrm{O}_{2} \mathrm{CCF}_{3}\right)_{6}(\mathrm{THF})_{3}\right]^{+}\left[\left(\mathrm{Me}_{3} \mathrm{Si}\right)_{3} \mathrm{CAl}\left(\mathrm{OC}(\mathrm{O}) \mathrm{CF}_{3}\right)_{3}\right]^{-}(18)$}

$\mathrm{CF}_{3} \mathrm{COOH}(1.99 \mathrm{~g}, 16.5 \mathrm{mmol}, 3 \mathrm{eq})$ was added to a solution of $\left(\mathrm{Me}_{3} \mathrm{Si}\right)_{3} \mathrm{CAlMe} \cdot \mathrm{THF}(2.00$ $\mathrm{g}, 5.50 \mathrm{mmol})$ in toluene $(20 \mathrm{~mL})$ and stirred for 1 day. All volatile substances were pumped off. The residue was dissolved in toluene/THF (5:1) and crystallized for one week at $-20^{\circ} \mathrm{C}$. 18 was obtained in $10 \%$ yield $(0.180 \mathrm{~g}, 0.11 \mathrm{mmol})$ (decomposing at $\left.135^{\circ} \mathrm{C}\right)$.

For the elemental analysis crystals of composition $\mathbf{1 8}+$ one molecule of $\mathrm{C}_{7} \mathrm{H}_{8}$ were used. Anal. Calcd for $\mathrm{C}_{47} \mathrm{H}_{59} \mathrm{Al}_{4} \mathrm{~F}_{27} \mathrm{O}_{22} \mathrm{Si}_{3}$ (1681.13): C, 33.58; H, 3.54. Found: C, 34.3; H, 3.8.

${ }^{1} \mathrm{H}$ NMR (200 MHz, THF-d $\left.8, \mathrm{ppm}\right): \delta 0.26(\mathrm{~s})$. 
${ }^{19} \mathrm{~F}$ NMR (188 MHz, THF-d 8 , ppm, external standard $\left.\mathrm{C}_{6} \mathrm{~F}_{6}\right): \delta-77.4(\mathrm{~s}, 1 \mathrm{~F}),-75.9(\mathrm{~s}, 1 \mathrm{~F})$, $-75.8(\mathrm{~s}, 1 \mathrm{~F})$.

${ }^{29} \mathrm{Si}$ NMR (99 MHz, THF-d $\left.8, \mathrm{ppm}\right): \delta-3.0(\mathrm{~s})$.

MS (FAB $($ pos) $): m / z 991\left(10 \%,\left[\mathrm{Al}_{3}\left(\mu_{3}-\mathrm{O}\right)\left(\mu-\mathrm{O}_{2} \mathrm{CCF}_{3}\right)_{6}(\mathrm{THF})_{3}\right]\right), 919\left(100 \%,\left[\mathrm{Al}_{3}\left(\mu_{3}-\mathrm{O}\right)-\right.\right.$ $\left.\left.\left(\mu-\mathrm{O}_{2} \mathrm{CCF}_{3}\right)_{6}(\mathrm{THF})_{2}\right]\right)$.

$\mathrm{MS}\left(\mathrm{FAB}_{(\text {neg })}\right): m / z, 597\left(100 \%,\left[\left(\mathrm{Me}_{3} \mathrm{Si}\right)_{3} \mathrm{CAl}\left(\mathrm{OC}(\mathrm{O}) \mathrm{CF}_{3}\right)_{3}\right]\right)$.

IR (CsI, cm ${ }^{-1}$ ): 2962 m, 1763 vs, 1735 vs, 1521 s, 1236 vs, 1179 vs, 1008 m, 860 vs, 803 vs, $735 \mathrm{~m}, 663 \mathrm{vs}, 566 \mathrm{~m}, 452 \mathrm{~m}, 410 \mathrm{~m}, 369$ vs. 


\section{Handling and Disposal of Wastes and Residual Wastes}

The solvents were distilled or condensed into cold traps and disposed into halogen-free or halogen-containing solvent containers.

The used NMR solvents were classified into halogen-free or halogen-containing solvents and disposed as heavy metal wastes and halogen containing wastes respectively.

The heavy metal residues were dissolved in nitric acid and stored in special containers for heavy metal wastes after neutralization. $\mathrm{Me}_{3} \mathrm{SnCl}$ and $\mathrm{Me}_{4} \mathrm{Sn}$ residues were stored in special containers for organic tin waste.

The drying agents $\left(\mathrm{CaCl}_{2}, \mathrm{CaH}_{2}, \mathrm{P}_{4} \mathrm{O}_{10}\right)$ were neutralized and disposed as base or acid wastes. Metallic sodium used for drying solvents was collected and recycled [108]. The residual sodium wastes were carefully hydrolyzed in cold 2-propanol and used for cleaning glassware together with residues of drying agents $(\mathrm{KOH})$ in the alkali bath.

The residue of the alkali bath used for cleaning glassware was disposed into the container for basic wastes.

The acid bath used for cleaning glassware was neutralized with $\mathrm{Na}_{2} \mathrm{CO}_{3}$ and the resulting $\mathrm{NaCl}$ solution was washed of in the water drainage system.

Amounts of various types of disposable wastes generated during work:

Metal containing wastes

Halogen-containing solvent wastes

Halogen-free solvent wastes

Acid wastes

Base wastes
$15 \mathrm{~L}$

$5 \mathrm{~L}$

$10 \mathrm{~L}$

$10 \mathrm{~L}$

$10 \mathrm{~L}$ 


\section{Crystal Data and Refinement Details}

Table CD1. Crystal data and structure refinement for the $2: 1$ mixture of compounds $7+\mathbf{8}$ [110].

Empirical formula

Formula weight

Temperature $(\mathrm{K})$

Crystal size $\left(\mathrm{mm}^{3}\right)$

Crystal system

Space group

$a(\AA)$

$b(\AA)$

$c(\AA)$

$\alpha(\mathrm{deg})$

$\beta(\operatorname{deg})$

$\gamma(\operatorname{deg})$

Volume $\left(\AA^{3}\right)$

Z

Density (calculated) $\left(\mathrm{Mg} / \mathrm{m}^{3}\right)$

Absorption coefficient $\left(\mathrm{mm}^{-1}\right)$

$F(000)$

$2 \theta$ range (deg)

Index ranges

Reflections collected

Independent reflections

Data / restraints / parameters

Goodness-of-fit on $F^{2}$

$R 1, w R 2[\mathrm{I}>2 \sigma(\mathrm{I})]$

$R, w R 2$ (all data)

Largest diff. peak and hole (e. $\AA^{-3}$ )
$\mathrm{C}_{82} \mathrm{H}_{154} \mathrm{Al}_{4} \mathrm{~F}_{12} \mathrm{OSi}_{12} \mathrm{Zr}_{4}$

2193.93

$150(2)$

$1.0 \times 0.4 \times 0.2$

triclinic

$P \overline{1}$

$9.560(2)$

$16.700(3)$

$17.537(4)$

77.90(3)

87.61(3)

83.79(4)

2720.9(9)

1

1.339

0.596

1142

$7-50$

$-11 \leq h \leq 11,-19 \leq k \leq 19,-15 \leq l \leq 20$

10726

$9606\left(R_{\text {int }}=0.0547\right)$

9593 / 0 / 539

1.055

$0.0362,0.0932$

$0.0432,0.1032$

0.615 and -0.640 
Table CD2. Crystal data and structure refinement for 8 [110].

Empirical formula

Formula weight

Temperature (K)

Crystal size $\left(\mathrm{mm}^{3}\right)$

Crystal system

Space group

$a(\AA)$

$b(\AA)$

$c(\AA)$

$\alpha(\operatorname{deg})$

$\beta$ (deg)

$\gamma(\mathrm{deg})$

Volume $\left(\AA^{3}\right)$

Z

Density (calculated) $\left(\mathrm{Mg} / \mathrm{m}^{3}\right)$

Absorption coefficient $\left(\mathrm{mm}^{-1}\right)$

$F(000)$

$2 \theta$ range (deg)

Index ranges

Reflections collected

Independent reflections

Data / restraints / parameters

Goodness-of-fit on $F^{2}$

$R 1, w R 2[\mathrm{I}>2 \sigma(\mathrm{I})]$

$R, w R 2$ (all data)

Largest diff. peak and hole (e. $\left.\AA^{-3}\right)$
$\mathrm{C}_{40} \mathrm{H}_{74} \mathrm{Al}_{2} \mathrm{~F}_{6} \mathrm{OSi}_{6} \mathrm{Zr}_{2}$

1089.93

173(2)

$0.5 \times 0.5 \times 0.2$

triclinic

$P_{1}^{-}$

$8.8011(2)$

12.5412(4)

12.5572(4)

83.80(1)

79.25(1)

77.45(1)

1286.42(7)

1

1.407

0.630

566

$3-57$

$-7 \leq h \leq 11,-15 \leq k \leq 16,-16 \leq l \leq 16$

8746

$6148\left(R_{\mathrm{int}}=0.0262\right)$

6125 / 0 / 268

1.165

$0.0519,0.1343$

$0.0611,0.1552$

1.510 and -0.918 
Table CD3. Crystal data and structure refinement for 9 [110].

( 0.5 molecules THF +0.5 molecules toluene are coordinated to one of the sodium atoms)

Empirical formula

Formula weight

Temperature (K)

Crystal size $\left(\mathrm{mm}^{3}\right)$

Crystal system

Space group

$a(\AA)$

$b(\AA)$

$c(\AA)$

$\alpha(\operatorname{deg})$

$\beta(\operatorname{deg})$

$\gamma(\mathrm{deg})$

Volume $\left(\AA^{3}\right)$

Z

Density (calculated) $\left(\mathrm{Mg} / \mathrm{m}^{3}\right)$

Absorption coefficient $\left(\mathrm{mm}^{-1}\right)$

$F(000)$

$2 \theta$ range (deg)

Index ranges

Reflections collected

Independent reflections

Data / restraints / parameters

Goodness-of-fit on $F^{2}$

$R 1, w R 2[\mathrm{I}>2 \sigma(\mathrm{I})]$

$R, w R 2$ (all data)

Largest diff. peak and hole (e. $\left.\AA^{-3}\right)$
$\mathrm{C}_{57.5} \mathrm{H}_{140} \mathrm{Al}_{4} \mathrm{~F}_{12} \mathrm{Na}_{4} \mathrm{O}_{3.5} \mathrm{Si}_{12}$

1652.62

133(2)

$0.5 \times 0.4 \times 0.4$

monoclinic

$P 2(1) / c$

26.465(2)

14.0333(11)

26.162(2)

90

97.766(4)

90

9627.3(13)

4

1.140

0.273

3540

$4-45$

$-28 \leq h \leq 28,-9 \leq k \leq 15,-28 \leq l \leq 28$

115448

$12574\left(R_{\text {int }}=0.1382\right)$

12574 / 60 / 814

0.956

$0.0615,0.1643$

$0.1089,0.1793$

0.943 and -0.636 
Table CD4. Crystal data and structure refinement for 10 [111].

Empirical formula

Formula weight

Temperature (K)

Crystal size $\left(\mathrm{mm}^{3}\right)$

Crystal system

Space group

$a(\AA)$

$b(\AA)$

$c(\AA)$

$\alpha(\operatorname{deg})$

$\beta(\mathrm{deg})$

$\gamma(\mathrm{deg})$

Volume $\left(\AA^{3}\right)$

Z

Density (calculated) $\left(\mathrm{Mg} / \mathrm{m}^{3}\right)$

Absorption coefficient $\left(\mathrm{mm}^{-1}\right)$

$F(000)$

$2 \theta$ range (deg)

Index ranges

Reflections collected

Independent reflections

Data / restraints / parameters

Goodness-of-fit on $F^{2}$

$R 1, w R 2[\mathrm{I}>2 \sigma(\mathrm{I})]$

$R, w R 2$ (all data)

Largest diff. peak and hole (e. $\left.\AA^{-3}\right)$
$\mathrm{C}_{36} \mathrm{H}_{86} \mathrm{Al}_{2} \mathrm{~F}_{4} \mathrm{Li}_{2} \mathrm{O}_{5} \mathrm{Si}_{6}$

911.43

133(2)

$0.7 \times 0.7 \times 0.6$

triclinic

$P \overline{1}$

$12.953(2)$

13.442(2)

$16.391(2)$

$89.33(2)$

$88.04(2)$

$70.02(2)$

$2680.6(7)$

2

1.129

0.236

988

$4-50$

$-15 \leq h \leq 15,-16 \leq k \leq 11,-19 \leq l \leq 19$

33521

$9477\left(R_{\text {int }}=0.0409\right)$

9477 / 924 / 706

1.049

$0.0490,0.1171$

$0.0730,0.1313$

0.316 and -0.313 
Table CD5. Crystal data and structure refinement for 11 [111].

Empirical formula

Formula weight

Temperature (K)

Crystal size $\left(\mathrm{mm}^{3}\right)$

Crystal system

Space group

$a(\AA)$

$b(\AA)$

$c(\AA)$

$\alpha(\operatorname{deg})$

$\beta(\mathrm{deg})$

$\gamma(\mathrm{deg})$

Volume $\left(\AA^{3}\right)$

Z

Density (calculated) $\left(\mathrm{Mg} / \mathrm{m}^{3}\right)$

Absorption coefficient $\left(\mathrm{mm}^{-1}\right)$

$F(000)$

$2 \theta$ range (deg)

Index ranges

Reflections collected

Independent reflections

Data / restraints / parameters

Goodness-of-fit on $F^{2}$

$R 1, w R 2[\mathrm{I}>2 \sigma(\mathrm{I})]$

$R, w R 2$ (all data)

Largest diff. peak and hole (e. $\left.\AA^{-3}\right)$
$\mathrm{C}_{50} \mathrm{H}_{121} \mathrm{Al}_{3} \mathrm{~F}_{10} \mathrm{Li}_{4} \mathrm{O}_{5} \mathrm{Si}_{9}$

1353.98

133(2)

$0.6 \times 0.6 \times 0.6$

rhombohedral

$R 3$

14.899(2)

14.899(2)

$30.472(6)$

90

90

120

$5857.9(16)$

3

1.151

0.247

2184

$3-50$

$-17 \leq h \leq 17,-17 \leq k \leq 17,-35 \leq l \leq 35$

37248

$4425\left(R_{\text {int }}=0.0490\right)$

4425 / 822 / 410

1.086

$0.0323,0.0841$

$0.0336,0.0873$

0.268 and -0.125 
Table CD6. Crystal data and structure refinement for 12 [109].

Empirical formula

Formula weight

Temperature (K)

Crystal size $\left(\mathrm{mm}^{3}\right)$

Crystal system

Space group

$a(\AA)$

$b(\AA)$

$c(\AA)$

$\alpha(\operatorname{deg})$

$\beta$ (deg)

$\gamma(\mathrm{deg})$

Volume $\left(\AA^{3}\right)$

Z

Density (calculated) $\left(\mathrm{Mg} / \mathrm{m}^{3}\right)$

Absorption coefficient $\left(\mathrm{mm}^{-1}\right)$

$F(000)$

$2 \theta$ range (deg)

Index ranges

Reflections collected

Independent reflections

Data / restraints / parameters

Goodness-of-fit on $F^{2}$

$R 1, w R 2[\mathrm{I}>2 \sigma(\mathrm{I})]$

$R, w R 2$ (all data)

Largest diff. peak and hole (e. $\left.\AA^{-3}\right)$
$\mathrm{C}_{20} \mathrm{H}_{54} \mathrm{Al}_{2} \mathrm{~F}_{5} \mathrm{KSi}_{6}$

651.22

200(2)

$0.6 \times 0.2 \times 0.2$

orthorhombic

P2(1)2(1)2(1)

8.9174(11)

$15.976(2)$

25.206(3)

90

90

90

$3591.0(8)$

4

1.205

0.433

1392

$7-50$

$-10 \leq h \leq 10,-19 \leq k \leq 19,-30 \leq l \leq 30$

10531

$6330\left(R_{\text {int }}=0.0361\right)$

$6330 / 571 / 438$

1.062

$0.0358,0.0744$

$0.0447,0.0796$

0.430 and -0.238 
Table CD7. Crystal data and structure refinement for 15 [76].

Empirical formula

Formula weight

Temperature $(\mathrm{K})$

Crystal size $\left(\mathrm{mm}^{3}\right)$

Crystal system

Space group

$a(\AA)$

$b(\AA)$

$c(\AA)$

$\alpha(\operatorname{deg})$

$\beta$ (deg)

$\gamma(\mathrm{deg})$

Volume $\left(\AA^{3}\right)$

Z

Density (calculated) $\left(\mathrm{Mg} / \mathrm{m}^{3}\right)$

Absorption coefficient $\left(\mathrm{mm}^{-1}\right)$

$F(000)$

$2 \theta$ range (deg)

Index ranges

Reflections collected

Independent reflections

Data / restraints / parameters

Goodness-of-fit on $F^{2}$

$R 1, w R 2[\mathrm{I}>2 \sigma(\mathrm{I})]$

$R, w R 2$ (all data)

Largest diff. peak and hole (e. $\left.\AA^{-3}\right)$
$\mathrm{C}_{30.5} \mathrm{H}_{70} \mathrm{AlF}_{2} \mathrm{NSi}_{3}$ (incl. 0.5 molecules of toluene)

600.13

213(2)

$0.8 \times 0.8 \times 0.6$

monoclinic

$P 2(1) / c$

$17.618(3)$

$12.917(2)$

17.681(3)

90

$101.32(2)$

90

$3.9451(12)$

4

0.999

0.169

1316

$7-45$

$-18 \leq h \leq 18,-13 \leq k \leq 13,-15 \leq l \leq 19$

9891

$5134\left(R_{\text {int }}=0.0395\right)$

$5130 / 0 / 348$

1.024

$0.1243,0.3381$

$0.1608,0.3874$

1.373 and -0.426 
Table CD8. Crystal data and structure refinement for $\mathbf{1 8}+$ toluene [96].

Empirical formula

Formula weight

Temperature (K)

Crystal size $\left(\mathrm{mm}^{3}\right)$

Crystal system

Space group

$a(\AA)$

$b(\AA)$

$c(\AA)$

$\alpha(\operatorname{deg})$

$\beta$ (deg)

$\gamma(\mathrm{deg})$

Volume $\left(\AA^{3}\right)$

Z

Density (calculated) $\left(\mathrm{Mg} / \mathrm{m}^{3}\right)$

Absorption coefficient $\left(\mathrm{mm}^{-1}\right)$

$F(000)$

$2 \theta$ range (deg)

Index ranges

Reflections collected

Independent reflections

Data / restraints / parameters

Goodness-of-fit on $F^{2}$

$R 1, w R 2[\mathrm{I}>2 \sigma(\mathrm{I})]$

$R, w R 2$ (all data)

Largest diff. peak and hole (e $\left.\cdot \AA^{-3}\right)$
$\mathrm{C}_{47} \mathrm{H}_{59} \mathrm{Al}_{4} \mathrm{~F}_{27} \mathrm{O}_{22} \mathrm{Si}_{3}$

1681.13

200(2)

$1.0 \times 0.7 \times 0.5$

rhombohedral

$R-3$

$18.313(2)$

18.313(2)

18.313(2)

53.472(17)

53.472(17)

53.472(17)

3679.3(7)

2

1.517

0.246

1708

$7-50$

$-14 \leq h \leq 21,-21 \leq k \leq 21,-12 \leq l \leq 18$

4633

$4341\left(R_{\text {int }}=0.1241\right)$

4341 / 599 / 368

1.013

$0.0712,0.1918$

$0.0889,0.2112$

1.284 and -0.698 


\section{References}

[1] N. N. Greenwood, A. Earnshaw, Chemistry of the Elements, $1^{\text {st }}$ ed., Pergamon, Oxford, Frankfurt, 1984.

[2] Holleman-Wiberg, Lehrbuch der anorganischen Chemie, $101^{\text {st }}$ ed., de Gruyter, Berlin, New York, 1985.

[3] E. Robert, J. E. Olsen, V. Danek, E. Tixhon, T. Ostvold, B. Gilbert, J. Phys. Chem. B 1997, 100, 9447.

[4] N. Dupont, P. Gredin, A. Caramanian, A. de Kozak, J. Solid State Chem. 1999, 147, 657.

[5] H. Schäfer, Angew. Chem. 1976, 88, 775; Angew. Chem. Int. Ed. Engl. 1976, 15, 780.

[6] B. J. Carter, W. D. Covey, F. P. DeHaan, J. Am. Chem. Soc. 1975, 97, 4783.

[7] L. Joubert, G. Picard, B. Silvi, F. Fuster, J. Mol. Struct. (Theochem) 1999, 463, 75.

[8] N. Herron, R. L. Harlow, D. L. Thorn, Inorg. Chem. 1993, 32, 2985.

[9] L. H. Li, T. H. Chan, Org. Lett. 2000, 2, 1129.

[10] K. A. Renner, J. B. Howard, Biochemistry 1996, 25, 2516.

[11] J. R. Serrano, C. ObejeroPaz, A. Scarpa, Biophys. J. 1997, 72, 43.

[12] G. Scholz, R. Stosser, J. A. Momand, A. Zehl, J. Klein, Angew. Chem. 2000, 112, 2570; Angew. Chem. Int. Ed. 2000, 39, 2516.

[13] K. Ziegler, E. Holzkamp, R. Köster, H. Lehmkuhl, Angew. Chem. 1955, 67, 213.

[14] D. A. Atwood, B. C. Yaerwood, J. Organomet. Chem. 2000, 600, 186.

[15] N. Herron, D. L. Thorn, R. L. Harlow, F. Davidson, J. Am. Chem. Soc. 1993, 115, 3028 .

[16] F.-Q. Liu, H. Gornitzka, D. Stalke, H. W. Roesky, Angew. Chem. 1993, 105, 447; Angew. Chem., Int. Ed. Engl. 1993, 32, 442.

[17] A. McKillop, J. D. Smith, I. J. Worrall, Organometallic Compounds of Aluminum, Gallium, Indium and Thallium, $1^{\text {st }}$ ed., Chapman and Hall, London, 1985.

[18] B. Neumüller, Coord. Chem. Rev. 1997, 158, 69.

[19] S. D. Waezsada, F.-Q. Liu, E. F. Murphy, H. W. Roesky, M. Teichert, I. Usón, H.-G. Schmidt, T. Albers, E. Parisini, M. Noltemeyer, Organometallics 1997, 16, 1260. 
[20] R. Poli, Chem. Rev. 1991, 91, 509.

[21] D. S. Breslow, N. R. Newburg, J. Am. Chem. Soc. 1957, 79, 5072.

[22] D. S. Breslow, N. R. Newburg, J. Am. Chem. Soc. 1959, 81, 81.

[23] G. Natta, P. Pino, G. Mazzanti, U. Giannini, J. Am. Chem. Soc. 1957, 79, 2975.

[24] W. Kaminsky, K. Külper, H. H. Brintzinger, Angew. Chem. 1985, 97, 507; Angew. Chem. Int. Ed. Engl. 1985, 24, 507.

[25] H. Sinn, W. Kaminsky, Adv. Organomet. Chem. 1980, 18, 99.

[26] R. F. Jordan, P. K. Bradley, R. E. LaPointe, D. F. Taylor, New J. Chem. 1990, 14, 505.

[27] M. Bochmann, Nachr. Chem. Tech. Lab. 1993, 41, 1220.

[28] M. Aulbach, F. Küber, Chem. unserer Zeit 1994, 28, 197.

[29] G. G. Hlatky, D. J. Upton, H. W. Turner, US Pat. Appl. 1990, 459,921; Chem. Abstr. 1991, 115, 256897v.

[30] M. Bochmann, S. J. Lancaster, Organometallics 1994, 13, 2235.

[31] T. Belgardt, J. Storre, H. W. Roesky, M. Noltemeyer, H.-G. Schmidt, Inorg. Chem. 1995, 34, 3821 .

[32] X. Yang, C. L. Stern, T. J. Marks, J. Am. Chem. Soc. 1994, 116, 10015.

[33] H. W. Roesky, A. Herzog, F.-Q. Liu, J. Fluorine Chem. 1995, 72, 183.

[34] A. Herzog, F.-Q. Liu, H. W. Roesky, A. Demsar, K. Keller, M. Noltemeyer, F. Pauer, Organometallics 1994, 13, 1251.

[35] D. Naumann, Fluor- und Fluorverbindungen, $1^{\text {st }}$ ed., Steinkopff, Darmstadt, 1980.

[36] W. Kaminsky, S. Lenk, V. Scholz, H. W. Roesky, A. Herzog, Macromolecules 1997, $30,7647$.

[37] A. Herzog, H. W. Roesky, Z. Zak, M. Noltemeyer, Angew. Chem. 1994, 106, 1035; Angew. Chem. Int. Ed. Engl. 1994, 33, 967.

[38] H. W. Roesky, I. Haiduc, J. Chem. Soc., Dalton Trans. 1999, 2249.

[39] G. Natta, G. Allegra, G. Perego, A. Zambelli, J. Am. Chem. Soc. 1961, 83, 5033.

[40] H. W. Roesky, M. Sotoodeh, Y. M. Xu, F. Schrumpf, M. Noltemeyer, Z. Anorg. Allg. Chem. 1990, 580, 131. 
[41] F. A. Cotton, G. Wilkinson, Advanced Inorganic Chemistry, $5^{\text {th }}$ ed., Wiley, New York, 1988.

[42] N. G. Jang, K. Kaji, M. Sorei, R. J. Wittebort, S. J. Geib, A. L. Rheingold, D. N. Hendrickson, Inorg. Chem. 1990, 29, 3547.

[43] C. Schnitter, K. Klimek, H. W. Roesky, T. Albers, H.-G. Schmidt, C. Röpken, E. Parisini, Organometallics 1998, 17, 2249.

[44] H. Hatop, H. W. Roesky, T. Labahn, C. Röpken, G. M. Sheldrick, M. Bhattacharjee, Organometallics 1998, 17, 4326.

[45] A. G. Avent, W.-Y. Chen, C. Eaborn, I. B. Gorrel, P. B. Hitchcock, J. D. Smith, Organometallics 1996, 15, 4343.

[46] H. W. Roesky, Inorg. Chem. 1999, 38, 5934.

[47] H. W. Roesky, M. Sotoodeh, M. Noltemeyer, Angew. Chem. 1992, 104, 869; Angew. Chem. Int. Ed. Engl. 1992, 31, 864.

[48] R. G. Pearson, J. Am. Chem. Soc. 1963, 85, 3533; Inorg. Chem. 1988, 27, 734; Coord. Chem. Rev. 1990, 100, 403.

[49] S. H. Strauss, Chem. Rev. 1993, 93, 927.

[50] V. Gutmann, Coord. Chem. Rev. 1976, 18, 225.

[51] H.-H. Brintzinger, D. Fischer, R. Mülhaupt, B. Rieger, R. Waymouth, Angew. Chem. 1995, 107, 1255; Angew. Chem. Int. Ed. Engl. 1995, 34, 1143.

[52] Y.-X. Chen, M. V. Metz, L. Li, C. L. Stern, T. J. Marks, J. Am. Chem. Soc. 1998, 120, 6287.

[53] H. Hatop, Diploma Thesis, Universität Göttingen, 1998.

[54] M. V. Bhatt, S. U. Kulkarni, Synthesis 1983, 249.

[55] E. F. Mooney, M. A. Qaseem, J. Chem. Soc., Chem. Commun. 1967, 230.

[56] C. Eaborn, N. Retta, J. D. Smith, P. B. Hitchcock, J. Organomet. Chem. 1982, 235, 265.

[57] C. L. Smith, Organometallics 1995, 14, 3098.

[58] S. D. Waezsada, F.-Q. Liu, C. E. Barnes, H. W. Roesky, M. L. Montero, I. Usón, Angew. Chem. 1997, 109, 2738; Angew. Chem. Int. Ed. Engl. 1997, 36, 2625. 
[59] C. Schnitter, H. W. Roesky, C. Röpken, R. Herbst-Irmer, H.-G. Schmidt, M. Noltemeyer, Angew. Chem. 1998, 110, 2059; Angew. Chem. Int. Ed. 1998, 37, 1952.

[60] E. Samuel, R. Ferner, M. Bigorgne, Inorg. Chem. 1973, 12, 881.

[61] J. Weidlein, V. Krieg, J. Organomet. Chem. 1968, 11, 9.

[62] A. F. Wells, Structural Inorganic Chemistry, $3^{\text {rd }}$ ed., Oxford University Press, London, Oxford, 1962.

[63] F.-Q. Liu, A. Kuhn, R. Herbst-Irmer, D. Stalke, H. W. Roesky, Angew. Chem. 1994, 106, 577; Angew. Chem. Int. Ed. Engl. 1994, 33, 555.

[64] J. L. Jolas, S. Hoppe, K. H. Whitmire, Inorg. Chem. 1997, 36, 3335.

[65] C. Schnitter, H. W. Roesky, T. Albers, H.-G. Schmidt, C. Röpken, E. Parisini, G. M. Sheldrick, Chem. Eur. J. 1997, 3, 1783.

[66] C. Rennekamp, H. Wessel, H. W. Roesky, P. Müller, H.-G. Schmidt, M. Noltemeyer, I. Usón, A. R. Barron, Inorg. Chem. 1999, 38, 5235.

[67] M. Elian, M. M. L. Chen, D. M. P. Mingos, R. Hoffmann, Inorg. Chem. 1976, 15, 1148.

[68] C. Schnitter, Doctoral Thesis, Göttingen, 1999.

[69] R. I. Hedge, M. A. Barteau, J. Catal. 1989, 120, 387.

[70] M. Sotoodeh, I. Leichtweis, H. W. Roesky, M. Noltemeyer, H.-G. Schmidt, Chem. Ber. 1993, 126, 913.

[71] H. W. Roesky, F. Schrumpf, M. Noltemeyer, J. Chem. Soc., Dalton Trans. 1990, 713.

[72] M. Schormann, H. W. Roesky, M. Noltemeyer, H.-G. Schmidt, J. Fluorine Chem. 2000, 101, 75 .

[73] M. R. Kopp, T. Kräuter, B. Werner, B. Neumüller, Z. Anorg. Allg. Chem. 1998, 624, 881.

[74] C. M. Cui, H. W. Roesky, M. Noltemeyer, M. F. Lappert, H.-G. Schmidt, H. Hao, Organometallics 1999, 18, 2256.

[75] B. Qian, D. L. Ward, M. R. Smith, Organometallics 1998, 17, 3070. 
[76] M. Schormann, K. S. Klimek, H. Hatop, S. P. Varkey, H. W. Roesky, C. Lehmann, C. Röpken, R. Herbst-Irmer, M. Noltemeyer, J. Solid State Chem. submitted 2001.

[77] A. P. Shreve, R. Mülhaupt, W. Fultz, J. Calabrese, W. Robbins, S. D. Ittel, Organometallics 1988, 7, 409.

[78] J. A. Jegier, D. A. Atwood, Bull. Soc. Chim. Fr. 1996, 133, 965.

[79] M. D. Healy, J. W. Ziller, A. R. Barron, J. Am. Chem. Soc. 1990, 112, 2949.

[80] W. Clegg, E. Lamb, S. T. Liddle, R. Snaith, A. E. H. Wheatley, J. Organomet. Chem. 1999, 573, 305.

[81] K. Ziegler, R. Köster, Liebigs Ann. Chem. 1957, 608, 1.

[82] R. Damrauer, M. Krempp, Organometallics 1990, 9, 1353.

[83] B. Neumüller, F. Gahlmann, Chem. Ber. 1993, 126, 1579.

[84] M. R. Kopp, B. Neumüller, Z. Anorg. Allg. Chem. 1998, 624, 1393.

[85] B. R. Jagirdar, E. F. Murphy, H. W. Roesky, Prog. Inorg. Chem. 1999, 48, 351.

[86] H. W. Roesky, A. Stasch, H. Hatop, C. Rennekamp, D. H. Hamilton, M. Noltemeyer, H.-G. Schmidt, Angew. Chemie. 2000, 112, 177; Angew. Chem. Int. Ed. 2000, 39, 171.

[87] D. Landini, H. Molinari, M. Penso, A. Rampoldi, Synthesis 1988, 953.

[88] D. Albanese, D. Landini, M. Penso, Tetrahedron Lett. 1995, 36, 8865.

[89] D. Chakraborty, S. Horchler, H. W. Roesky, M. Noltemeyer, H.-G. Schmidt, Inorg. Chem. 2000, 39, 3995.

[90] M. Ferbinteanu, H. W. Roesky, F. Cimpoesu, M. Atanasov, S. Köpke, R. Herbst-Irmer, Inorg. Chem. 2001, in press.

[91] M. T. Andras, S. A. Duraj, A. F. Hepp, P. E. Fanwick, M. M. Bodnar, J. Am. Chem. Soc. 1992, 114, 786.

[92] A. Pandey, V. D. Gupta, H. Nöth, Eur. J. Inorg. Chem. 1999, 1291.

[93] A. Klemp, H. Hatop, H. W. Roesky, H.-G. Schmidt, M. Noltemeyer, Inorg. Chem. 1999, 38, 5832 .

[94] (a) R. D. Cannon, R. P. White, Prog. Inorg. Chem. 1988, 36, 195; (b) L. Meesuk, V. A. Jayasooriya, R. D. Cannon, J. Am. Chem. Soc. 1987, 109, 2009. 
[95] Personal communication M. Cimpoesu. The calculation will be repeated on the basis of STO 6-311G*, with $\mathrm{CH}_{3} \mathrm{COO}^{-}$and $\mathrm{CF}_{3} \mathrm{COO}^{-}$(in progress).

[96] H. Hatop, M. Cimpoesu, H. W. Roesky, H.-G. Schmidt, M. Noltemeyer, in preparation for Inorg. Chem..

[97] R. F. W. Bader, Atoms in Molecules - A Quantum Theory, Oxford University Press, London, Oxford, 1990; Acc. Chem. Res. 1985, 18, 9.

[98] The calculations were carried out with the GAMESS package: M. W. Schmidt, K. K. Baldridge, J. A. Boatz, S. T. Elbert, M. S. Gordon, J. H. Jensen, S. Koseki, N. Matsunaga, K. A. Nguyen, S. J. Su, T. L. Windus, J. Comput. Chem. 1993, 14, 1347.

[99] The analysis of the resulting gradient field and Laplacian of electron density [97] offers a clear image of the bonding condition. The map of Laplacian $\left(\nabla^{2} \rho\right)$ in the coordination plane of one ligand proves the existence of misdirected lone pairs. For the $a b$ initio calculations (in RHF [98] and DFT frames) the molecular structure was idealized to $\mathrm{D}_{3 \mathrm{~h}}$ symmetry [95].

[100] D. F. Shriver, M. A. Drezdzon, The Manipulation of Air-Sensitive Compounds, $2^{\text {nd }}$ ed., Wiley-Interscience, New York, 1986.

[101] Autorenkollektiv, Organikum, 16. Aufl., VEB Deutscher Verlag der Wissenschaften, Berlin, 1986.

[102] T. Kottke, D. Stalke, J. Appl. Crystallogr. 1993, 26, 615.

[103] G. M. Sheldrick, SHELXTL-PLUS, Siemens X-Ray Instruments, Madison, WI, 1990.

[104] G. M. Sheldrick, Acta Crystallogr. Sect. A 1990, 46, 467.

[105] P. C. Wailes, H. Weigold, A. P. Bell, J. Organomet. Chem. 1972, 42, 155.

[106] E. Krause, Ber. Dtsch. Chem. Ges. 1918, 51, 1447.

[107] M. D. Healy, J. W. Ziller, A. R. Barron, Organometallics 1992, 11, 3041.

[108] B. Hübler-Blank, M. Witt, H. W. Roesky, J. Chem. Educ. 1993, 70, 408.

[109] H. Hatop, M. Schiefer, H. W. Roesky, H.-G. Schmidt, M. Noltemeyer, J. Fluorine Chem. 2001, submitted.

[110] H. Hatop, H. W. Roesky, T. Labahn, A. Fischer, H.-G. Schmidt, M. Noltemeyer, Organometallics 2000, 19, 937. 
[111] H. Hatop, M. Schiefer, H. W. Roesky, R. Herbst-Irmer, T. Labahn, Organometallics 2001 in press. 


\section{Lebenslauf}

Hagen Hatop, geboren am 15. August 1968 in Einbeck/Deutschland

Eltern: Resi Hatop, geb. Grothe Ulrich Hatop

Staatsangehörigkeit: deutsch

Familienstand: $\quad$ ledig

Ausbildung:

$1975-1979$

Grundschule Dassensen

$1979-1981$

Orientierungsstufe Einbeck

$1981-1985$

Löns-Real-Schule Einbeck

$1985-1986$

Berufsgrundbildungsjahr Agrar an der Berufsschule Northeim

$1986-1987$

2. landwirtschaftliches Lehrjahr bei Hans Dutz, Bördel

$1987-1988$

3. landwirtschaftliches Lehrjahr bei Hans-Hermann Hansen, Weferlingsen

1988 - Mai 1991

Konrad-Michelsenschule, Hildesheim

30.05.1991

Allgemeine Hochschulreife

$07.1991-06.1992$

Bundeswehr, Nachschubeinheit für Sonderwaffen

Hochschulausbildung

01.Oktober 1992 -

Februar 1998

Studium der Chemie an der

Februar 1998

Georg-August-Universität zu Göttingen

Dezember 1998

Diplomprüfung

Gustav-Tammann-Preis für hervorragende Leistungen in der

Diplomarbeit

März 1998 - Juli 2001

Anfertigung der Dissertation unter Anleitung von Professor Dr. Dr. h. c. mult. H. W. Roesky 